\title{
PROPOSTA DE MODELO PARA O DESENVOLVIMENTO DE PROJETOS MINERAIS SUSTENTÁVEIS NO BRASIL
}

Dissertação apresentada à Escola Politécnica da Universidade de São Paulo para a obtenção do título de Mestre em Engenharia.

São Paulo 


\section{PROPOSTA DE MODELO PARA O DESENVOLVIMENTO DE PROJETOS MINERAIS SUSTENTÁVEIS NO BRASIL}

Dissertação apresentada à Escola Politécnica da Universidade de São Paulo para a obtenção do título de Mestre em Engenharia.

Área de Concentração:

Engenharia Mineral

Orientador:

Prof. Dr. Giorgio De Tomi

\section{São Paulo}


Este exemplar foi revisado e corrigido em relação à versão original, sob responsabilidade única do autor e com a anuência de seu orientador.

São Paulo, de junho de 2015.

Assinatura do autor

Assinatura do orientador

Catalogação-na-publicação

\section{Passos, Alexandre Orlandi}

Proposta de modelo para o desenvolvimento de projetos minerais sustentáveis no Brasil / A.O. Passos. -- versão corr. -São Paulo, 2015.

$110 \mathrm{p}$.

Dissertação (Mestrado) - Escola Politécnica da Universidade de São Paulo. Departamento de Engenharia de Minas e de Petróleo.

1.Sustentabilidade 2.Mineração 3.Projetos (Desenvolvimento) I.Universidade de São Paulo. Escola Politécnica. Departamento de Engenharia de Minas e de Petróleo II.t. 
Agradeço a Deus por tudo que Ele tem me propiciado nesta vida e dedico este trabalho a minha esposa Cida, as minhas filhas Mila e Carol e a minha mãe, Maria Celia, que não mediu esforços, para que eu pudesse estudar com tranquilidade. 


\section{AGRADECIMENTOS}

Agradeço ao meu orientador, Prof. Dr. Giorgio Francesco Cesare de Tomi, pelas contribuições que me auxiliaram na confecção deste trabalho. Agradeço também as empresas por propiciarem a realização dos projetos e aos professores da Escola Politécnica da Universidade de São Paulo e da Escola de Minas da Universidade Federal de Ouro Preto que contribuíram nos projetos que subsidiam este trabalho.

Agradeço a colaboração de meus colegas do LAPOL, os engenheiros de minas Alizeibek Nader, Richardson Agra, Maurício Dompieri, Emanuel Itaque, Jacopo Seccatore, Tatiane Marin e Jonas Paulino, a engenheira agrônoma Miriam Okumura, a economista Anne Kalio, o físico Antonio Carlos Martins e a secretária Elisangela Romanelli que contribuíram de diversas formas para o desenvolvimento do trabalho.

Agradeço a minha cunhada, a historiadora Valéria Zanetti, pelo auxílio no entendimento das questões históricas que dificultam o desenvolvimento tecnológico no Brasil e ao Dr. Gabriel Costa Lima pelo auxílio nos aspectos associados simulação e análise de risco.

Agradeço aos profissionais da FINEP pela atuação profissional, transparente e construtiva na análise dos projetos, que foi de grande valia para estruturação da metodologia proposta.

Finalmente agradeço a todos os professores, colegas e amigos que contribuíram para o meu aperfeiçoamento profissional e pessoal; especialmente, aos professores Laurindo Leal Filho, Marcello Veiga, Arthur Pinto Chaves, Homero Delboni, Ricardo Cabral, Edison Gonçalves, José Roberto Simões, Isak kruglianskas, Clandia Gomes, Fernando Gabriel Araujo, Gabriel Costa Lima, Ruben Solé, Jefferson Mendes, e Carlos Barreiro, a secretária Maristela Martins, o engenheiro de minas Newton Martins da Cunha, os geólogos Ronaldo Eisele e Richard Margutti e os engenheiros químicos Arnaldo Andrade e René Ferreira Junior. 


\section{RESUMO}

A mineração brasileira, assim como todo o setor da industria de transformação, tem perdido competitividade ao longo do tempo, além disso o Brasil necessita tornar suas operações mais sustentáveis e agregar valor a sua produção industrial.

A mineração é um setor onde esta questão se torna mais crítica, pois além de poder gerar forte impacto ambiental, a produção é fortemente baseada em commodities, com baixo valor agregado. Um dos caminhos para superar os obstáculos ao crescimento sustentável da mineração no Brasil é o desenvolvimento de projetos minerais inovadores.

As condições estabelecidas pelo governo brasileiro para incentivo à inovação são muito abrangentes, práticas e atrativas; os recursos para financiamento são abundantes e os mecanismos para operacionalização extremamente profissionais. No entanto, na maioria das empresas brasileiras estão presentes a aversão ao risco, a falta das práticas de planejamento e de gestão de projetos e a visão de curto prazo focada na atuação corretiva, fatores que não favorecem o ambiente inovador nas empresas.

Ou seja, o grande desafio para a mudança da mineração brasileira, tornando-a mais sustentável e competitiva, está na forma de pensar dos seus lideres; pois as condições existentes para desenvolvimento tecnológico estão disponíveis, mas as empresas necessitam aprender a utilizá-las.

Este é um trabalho de pesquisa aplicada, que apresenta uma proposta de metodologia para desenvolvimento de projetos minerais sustentáveis, que foi utilizada por algumas empresas e obteve resultados muito positivos; com isto, é possível estabelecer um caminho que favoreça a mudança da cultura predominante, facilitando o desenvolvimento de inovações na mineração e contribuindo para o seu ganho de competitividade e sustentabilidade.

A aplicação da metodologia proposta foi aplicada em um caso hipotético de mineração de ferro e os resultados foram muito positivos, demonstrando que o projeto inovador e sustentável seria muito mais competitivo que um tradicional, principalmente, em momentos de mercado em baixa.

Palavras-chave: inovação, gestão, competitividade, mineração, financiamento, incentivos 


\section{ABSTRACT}

The Brazilian mining as well as the entire industrial sector has lost competitiveness over time, furthermore Brazil needs to make its operations more sustainable and add value to its industrial production.

Mining is an industry where this issue becomes more critical, besides generating significant environmental impacts, production is heavily based on commodities with low value aggregate. One pathway to overcome obstacles for a sustainable growth of mining in Brazil is the development of technological innovation projects.

The established conditions by the Brazilian government for encouraging technological innovation are very comprehensive, practical and attractive; plentiful resources for funding and mechanisms for extremely professional operation. However, in most Brazilian companies risk aversion is present, lack of management practices and a short-termism for corrective actions, and are the factors that do not support an improved environment for innovation in companies.

The biggest challenge for changing the Brazilian mining, making it more sustainable and competitive, is the leadership mind; because there are available conditions for technological development but companies need to learn how to use it.

This work is an applied research, which proposes a methodology for managing innovation for Brazilian mining has been used by some companies and obtained very positive results; with this, it is possible to establish a path for changing the current companies' culture, facilitating the development of innovations in mining and contributing to its competitiveness and sustainability.

The proposed methodology was applied in a hypothetical case in an iron mining and the results were very positive, it showed that sustainable and innovator project would be more competitive than a traditional one even in times when market goes depressed.

Keywords: innovation, management, competitiveness, mining, finance, incentives. 


\section{LISTA DE FIGURAS}

Figura 1: Evolução do Valor da Produção Mineral Brasileira (DNPM/IBRAM, 2012)

Figura 2: Evolução Balança Comercial Mineral Brasileira (MDIC, 2012) ......... 31

Figura 3: Exportações Minerais Brasileiras em 2012 (MDIC, 2012)................ 32

Figura 4: Comparativo Mercado Minério Ferro Brasil e Austrália..................... 33

Figura 5: Evolução da Produtividade da Indústria de Transformação Brasileira

Figura 6: Produtividade da Mineração Brasileira de Ferro (mil t/empregado/ano)

Figura 7: Produtividade da Mineração Brasileira de Ferro (mil t/empregado/ano)

Figura 8: As camadas de envolvimento dos trabalhadores na mineração ....... 48

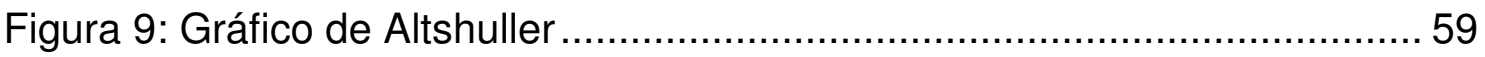

Figura 10: Elementos- Chave do Ecossistema de Inovação do Vale do Silício 62

Figura 11: Modelo Esquemático de Relação Pessoal para Inovação 63

Figura 12: Características Necessárias para um Ecossistema de Inovação

Eficiente 64

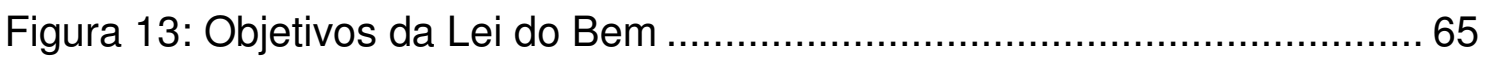

Figura 14: Resultados da Inovação e seus Componentes ................................ 66

Figura 15: Mecanismos de Financiamento para Inovação ................................. 68

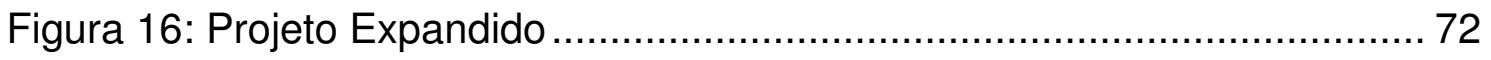

Figura 17: Projeto Expandido Aplicado à Mineração...................................... 73

Figura 18: Cultura de Inovação e Competitividade......................................... 75

Figura 19: Metodologia proposta............................................................... 76

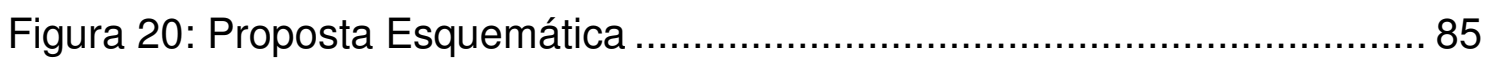

Figura 21: Abrangência do Financiamento de Inovação de um Projeto Mineral

Figura 22: Valor esperado do VPL em função de diferentes parâmetros da distribuição log-normal 99

Figura 23: Risco de VPL negativo em função de diferentes parâmetros da distribuição log-normal

Figura 24: Diferença de VPL entre os modelos inovador e tradicional em função de diferentes parâmetros da distribuição log-normal. 
Figura 25: Faixa crítica de risco do VPL 


\section{LISTA DE TABELAS}

Tabela 1: Diretrizes econômicas específicas para o setor de mineração e metais 20

Tabela 2: Diretrizes ambientais específicas para o setor de mineração e metais

Tabela 3: Diretrizes sociais específicas para o setor de mineração e metais .. 22

Tabela 4: Comparativo de Preço por Quilo (ABIMAQ, 2011) 30

Tabela 5: Diferencial de Custo na Produção Nacional em Relação aos

Concorrentes Internacionais (ABIMAQ, 2011) 30

Tabela 6: Comparativo de Incentivos Internacionais para P\& 38

Tabela 7: Incentivos Fiscais para Investimentos em PD\&I por Setor. 38

Tabela 8: Tabela de Avaliação das Propostas de Projetos de Inovação. 79

Tabela 9: Premissas consideradas na modelagem. 90

Tabela 10: Resultados Modelo Tradicional 92

Tabela 11: Resultados Modelo Inovador..... 93

Tabela 12: Dados considerados em cada um dos modelos 96

Tabela 13: Avaliação do Impacto das Variáveis Críticas 97

Tabela 14: Parâmetros utilizados nas simulações 98 


\section{SUMÁRIO}

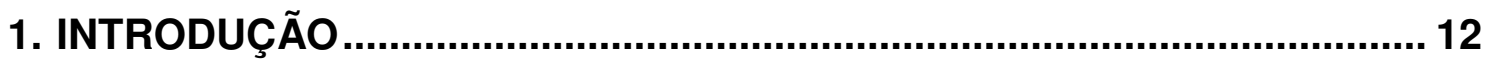

1.1 Objetivo da Pesquisa........................................................ 12

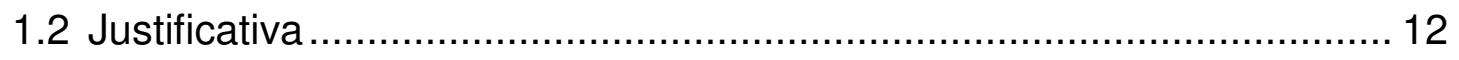

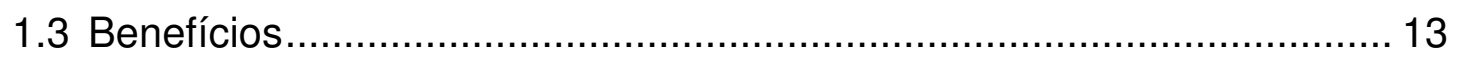

1.4 Solução Proposta .................................................................. 14

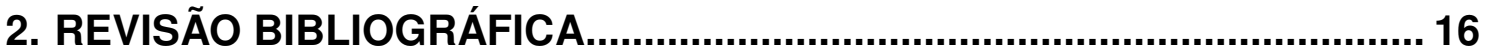

2.1 Competitividade da Mineração Brasileira........................................ 29

2.2 Métodos de Gestão e Inovação....................................................... 39

2.3 Abordagens de Gestão da Inovação ................................................ 40

2.3.1. Melhoria Contínua ........................................................... 42

2.3.2. Inovação de Alto Envolvimento ........................................ 43

2.3.3. Inovação Contínua .................................................. 43

2.3.4. Inovação Aberta ................................................... 43

2.3.5. Inovação Baseada na Prática.......................................... 45

2.3.6. Funcionários Orientados para Inovação............................... 45

2.4. Inovação no Setor de Mineração no Brasil........................................ 46

2.5. Proposta de Abordagem de Gestão da Inovação .............................. 48

2.6 Fatores Históricos e Culturais que Dificultam o Desenvolvimento da Inovação no Brasil ................................................................. 49

3. MODELO PROPOSTO ........................................................................ 55

3.1 Construção de Modelos do Projeto Mineração (produção, custos, teores, preços, etc.) Segundo a Nova Abordagem e Modelo Tradicional......... 58

3.2. Conceitos que Nortearam a Abordagem Proposta............................ 59

3.2.1. Inovação é Mais Simples que o Considerado Normalmente ...........59

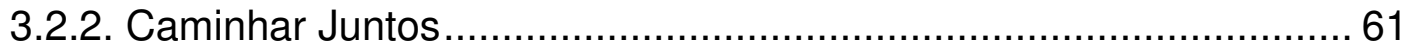

3.2.3. Oportunidades de Redução de Risco Financeiro .......................6 67 
3.2.4. Projeto Expandido

3.3. Proposta de Metodologia de Gestão de Inovação para a Mineração Brasileira. 74

3.3.1. Planejamento Estratégico...................................................... 78

3.3.2. Apresentação das Propostas de Projetos ....................................... 80

3.3.3. Seleção das Propostas de Projetos ............................................. 81

3.3.4. Estruturação do Plano de Execução dos Projetos ............................ 82

3.3.5. Obtenção do Financiamento Subsidiado para a Inovação................ 83

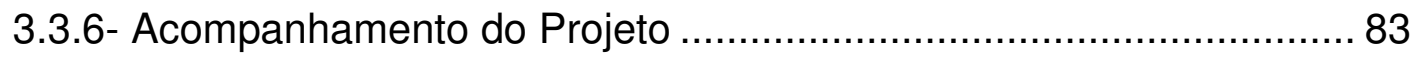

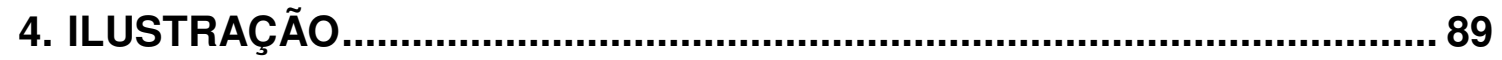

4.1. Identificação das Variáveis Críticas que Impactam nos Fluxos de Caixa Anuais do Projeto bem como em seus Indicadores. 97

4.2. Detalhamento da Simulação de Monte Carlo........................................ 97

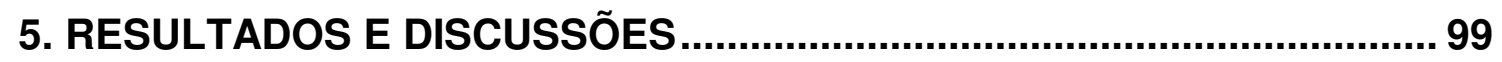

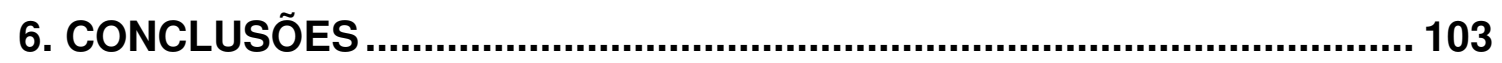

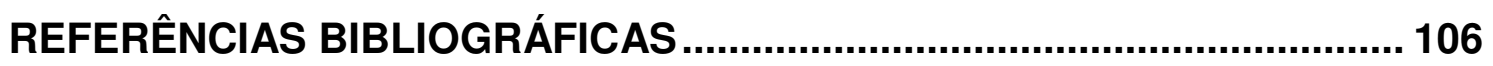




\section{INTRODUÇÃO}

\subsection{Objetivo da Pesquisa}

Estabelecer uma proposta de metodologia para o desenvolvimento de projetos minerais sustentáveis no Brasil.

\section{Objetivos Específicos:}

1. Efetuar um diagnóstico da mineração brasileira em relação a sustentabilidade;

2. Analisar os principais obstáculos para a sustentabilidade da mineração brasileira;

3. Identificar as oportunidades de contribuição para a sustentabilidade da mineração brasileira;

4. Estruturar uma proposta de metodologia para o desenvolvimento de projetos minerais sustentáveis no Brasil;

5. Avaliar o potencial impacto da metodologia proposta para a sustentabilidade da mineração brasileira.

\subsection{Justificativa}

A inovação é um fator fundamental para combater o processo de desindustrialização que está ocorrendo no Brasil (PROTEC, 2012), acarretando uma redução de 40,5\% no superavit da balança comercial de 2012 em relação a 2011 (Ministério do Desenvolvimento, Indústria e Comércio Exterior, 2013). O desenvolvimento da cultura de inovação nas minerações brasileiras propiciará o ganho de competitividade e sustentabilidade do setor mineral, podendo ocasionar os seguintes benefícios:

- Maior rentabilidade para os empreendimentos minerais no Brasil, com menores riscos;

- Maior capacidade de investimento e atratividade para capital externo;

- Aumento na quantidade de projetos minerais implementados no país; 
- Melhor aproveitamento do patrimônio mineral brasileiro e aumento na arrecadação de impostos;

- Geração de empregos formais, predominantemente em regiões pouco desenvolvidas;

- Capacitação de pessoal;

- Favorecimento do desenvolvimento regional sustentável fora dos grandes centros urbanos;

- Avanço no beneficiamento e transformação (verticalização) dos bens minerais para maior agregação de valor no Brasil;

- Desenvolvimento de um ecossistema de inovação para o ganho de competitividade e sustentabilidade do setor.

Normalmente no Brasil os projetos minerais são desenvolvidos de forma tradicional, com baixo nível de inovação. Os fatores listados a seguir contribuem para este tipo de abordagem:

- Falta de financiamento para as atividades anteriores à implantação produtiva;

- Recursos escassos para as fases de estudos e projetos;

- Consideração apenas de tecnologias consagradas e soluções tradicionais;

- Projeto focado essencialmente na atividade produtiva;

- Demora para obtenção de licenciamento ambiental.

\subsection{Benefícios}

Este trabalho visa contribuir para a sustentabilidade da mineração brasileira propiciando os seguintes benefícios:

- Financiamento subsidiado para as atividades anteriores à implantação produtiva;

- Aumento de recursos para as fases de estudos e projetos;

- Fomento a introdução de novas tecnologias, melhorando o desempenho e reduzindo os impactos ambientais; 
- Fortalecimento da integração do empreendimento com as comunidades locais para favorecer o desenvolvimento regional e o ganho de sua competitividade;

- Implementação da unidade-piloto de forma rápida para auxiliar no esclarecimento de dúvidas e facilitar a implantação de uma operação produtiva competitiva e sustentável.

\subsection{Solução Proposta}

A solução proposta para o desenvolvimento de projetos minerais sustentáveis no Brasil, é uma metodologia que possibilite utilizar, de forma otimizada, as condições existentes para o fomento da inovação no Brasil, contribuindo para a mudança cultural no setor mínero-metalúrgico, facilitando o desenvolvimento de inovações de forma sistematizada e buscando resultados mais abrangentes (econômico, social e ambiental), com maiores investimentos, porém, com riscos e prazos menores, ou seja, mineração mais sustentável.

Essa abordagem contempla os seguintes aspectos:

- Planejamento estratégico de PD\&l;

- Definição das inovações a serem avaliadas em cada projeto;

- Entendimento claro dos desafios associados a cada projeto de forma integrada às três dimensões: econômica, ambiental e social;

- Elaboração de escopo expandido para cada projeto mineral a ser desenvolvido (pesquisas básicas, desenvolvimento de protótipos em laboratório, implantação de solução completa em operação-piloto, avaliação da operação-piloto, análise de viabilidade de replicação);

- Estruturação de cada projeto a ser desenvolvido (objetivos, equipe, orçamento, cronograma, oportunidades de fomento, análise de viabilidade e aprovação para o encaminhamento);

- Obtenção de financiamento subsidiado para os projetos minerais;

- Planejamento e gestão de projetos com base nas demandas do processo de inovação (foco em resultados alinhados ao objetivo do projeto, 
comprometimento, motivação, flexibilidade - mais apoio e orientação e menos burocracia, rigor e cobrança);

- Elaboração de estratégia de replicação e plano de negócio;

- Obtenção de incentivos fiscais. 


\section{REVISÃo BIBLIOGRÁFICA}

\section{O que é Sustentabilidade?}

O termo sustentabilidade está cada vez mais presente no ambiente empresarial. A definição de sustentabilidade mais difundida é a da Comissão Brundtland (WCED, 1987), a qual considera que o desenvolvimento sustentável deve satisfazer às necessidades da geração presente sem comprometer as necessidades das gerações futuras. Essa definição deixa claro um dos princípios básicos de sustentabilidade, a visão de longo prazo, uma vez que os interesses das futuras gerações devem ser analisados.

A verdade é que, desde a definição da Comissão Brundtland, já surgiram inúmeras definições e, com certeza, existirão muitas outras no futuro, porém, o ponto comum em todas elas, quando analisadas detalhadamente, está nas dimensões que compõem o termo sustentabilidade. A maioria dos estudos afirma que sustentabilidade é composta de três dimensões que se relacionam: econômica, ambiental e social (Claro, 2008).

A dimensão econômica inclui não só a economia formal, mas também as atividades informais que provêm de serviços aos indivíduos e aumentam, assim, a renda monetária e o padrão de vida. A dimensão ambiental ou ecológica estimula empresas a considerarem o impacto de suas atividades sobre o meio ambiente, na forma de utilização dos recursos naturais, e contribui para a integração da administração ambiental na rotina de trabalho. A dimensão social consiste no aspecto social relacionado às qualidades dos seres humanos, como suas habilidades, dedicação e experiências, abrangendo tanto o ambiente interno da empresa quanto o externo (ALMEIDA, 2002).

\section{Como pode ser vista a sustentabilidade na mineração?}

Segundo Enriquez (2009), o conceito normativo de Desenvolvimento Sustentável (World Comission, 1987), amplamente difundido, aparentemente conflita com a atividade mineral, uma vez que os bens minerais são, por definição, recursos não-renováveis. Para Eggert (2000) é teoricamente simples pensar em sustentabilidade quando se trata de recursos renováveis, porém isso 
é mais complicado para o caso dos recursos não-renováveis que existem em quantidades fixas. Por exemplo, quando o petróleo se esgotar, só é possível pensar em sustentabilidade em uma perspectiva global no caso de se descobrirem outras fontes alternativas de energia.

No entanto, a inovação na mineração pode contribuir para a criação de uma nova visão, em que a mineração poderá passar a aproveitar minerais que atualmente não são viáveis economicamente, fato semelhante ao ocorrido com os itabiritos, que não eram viáveis no Brasil até que as jazidas de hematita se tornaram mais escassas e o avanço tecnológico viabilizou a sua exploração econômica.

\section{Quais as iniciativas para promover a sustentabilidade na mineração?}

O International Council on Mining and Metals (ICMM), que consiste em um fórum sediado em Londres, foi fundado em outubro de 2001, para representar as principais empresas internacionais de mineração e metais, com o objetivo de aprimorar a atuação das companhias do setor (ICMM, 2010).

Para atingir seu objetivo, o ICMM desenvolve parcerias com diversas instituições, como Organizações Não Governamentais (ONGs), Organismos Internacionais, Universidades e outras. Por meio dessas parcerias, o ICMM atua em várias questões, como a mudança climática, a saúde e a segurança das comunidades, o impacto da mineração na biodiversidade, os direitos dos povos indígenas e também os reflexos na indústria e as consequências futuras do surgimento de novos agentes globais. A proposta consiste em estimular as mineradoras a aprender como é possível compartilhar práticas positivas (ICMM, 2010).

Segundo o ICMM (2010), o Conselho desenvolveu, em 2003, um modelo para o desenvolvimento sustentável, denominado Sustainable Development Framework, a fim de assegurar uma padronização entre seus integrantes através da adoção e do cumprimento das políticas estipuladas pelo modelo. O framework é composto por dez princípios, relatórios públicos e auditoria independente, estando entre as mais avançadas iniciativas voluntárias em sua categoria, de forma a contribuir para melhorar a performance da indústria de mineração.

Os dez princípios foram elaborados com base em outros padrões globais orientadores, como a Declaração do Rio 1992, a Global Reporting Initiative, as 
Diretrizes da Organização para Cooperação e Desenvolvimento Econômico (OCDE) para empresas multinacionais, as políticas operacionais do Banco Mundial, a Convenção da OCDE sobre o combate à corrupção, as Convenções da Organização Internacional do Trabalho (OIT) 98, 169, 176 e os princípios voluntários sobre direitos humanos e segurança (ICMM, 2008).

Os dez princípios estabelecidos pelo ICMM para o Desenvolvimento Sustentável do Setor Mineral são:

1. Implementar e manter práticas comerciais éticas e sistemas íntegros de governança corporativa;

2. Integrar as considerações sobre o desenvolvimento sustentável ao processo de tomada de decisões corporativas;

3. Defender os direitos humanos fundamentais e respeitar a cultura, os costumes e os valores dos funcionários e de outras pessoas afetadas pelas atividades da empresa;

4. Implementar estratégias de gestão de riscos baseadas em dados válidos e na ciência bem fundamentada;

5. Buscar a melhoria contínua de nossa atuação nas áreas de saúde e segurança;

6. Buscar a melhoria contínua de nossa atuação na área ambiental;;.

7. Contribuir para a conservação da biodiversidade e das abordagens integradas ao planejamento do uso da terra;

8. Facilitar e incentivar o desenvolvimento, a utilização, a reutilização, a reciclagem e o descarte de nossos produtos de maneira responsável;

9. Contribuir para o desenvolvimento social, econômico e institucional das comunidades do entorno;

10. Estabelecer acordos efetivos e transparentes com as partes interessadas para o comprometimento, a comunicação e a verificação independente das informações.

Outra importante iniciativa é a definição de indicadores de sustentabilidade para a indústria mineral, apresentados no suplemento elaborado pela Global Reporting Initiative (GRI-2002). O Mining and Metals Sector Supplement consiste em uma versão das diretrizes G3 dos indicadores GRI adequada para o setor de mineração e metais, incluindo comentários específicos para o setor sobre o 
conteúdo das diretrizes e indicadores de desempenho adicionais, de forma a garantir que os relatórios de sustentabilidade englobem eficazmente questões setoriais fundamentais.

O Mining and Metals Sector Supplement foi desenvolvido em duas fases, tendo como coorganizador o International Council on Mining and Metals (ICMM). No período de outubro de 2003 a fevereiro de 2005, um grupo de trabalho desenvolveu uma versão-piloto do suplemento para o setor de mineração e metais, em conformidade com as diretrizes GRI de 2002, contendo um projeto de conjunto de indicadores.

Em 2008, um segundo grupo de trabalho reuniu-se para finalizar o suplemento. O grupo analisou relatos de experiência com a versão-piloto, atualizou 0 suplemento de acordo com as diretrizes G3 de 2006 e também desenvolveu protocolos para os indicadores. Ambas as fases incluíram consultas públicas, nas quais especialistas foram convidados a apresentar suas sugestões e comentários sobre a versão. Em março de 2010, foi lançada a versão final do suplemento na convenção Prospectors and Developers Association of Canada.

Outra importante iniciativa referente a indicadores de sustentabilidade para a indústria mineral consiste no suplemento elaborado pela Global Reporting Initiative (GRI). O Mining and Metals Sector Supplement consiste em uma versão das diretrizes G3 dos indicadores GRI adequada para o setor de mineração e metais, incluindo comentários específicos para o setor sobre o conteúdo das diretrizes e indicadores de desempenho adicionais, de forma a garantir que os relatórios de sustentabilidade englobem eficazmente questões setoriais fundamentais.

O Mining and Metals Sector Supplement foi desenvolvido em duas fases, tendo como coorganizador o International Council on Mining and Metals (ICMM). No período de outubro de 2003 a fevereiro de 2005, um grupo de trabalho multistakeholders desenvolveu uma versão-piloto do suplemento para o setor de mineração e metais, em conformidade com as diretrizes GRI de 2002, contendo um projeto de conjunto de indicadores.

Em 2008, um segundo grupo de trabalho reuniu-se para finalizar o suplemento. O grupo analisou relatos de experiência com a versão-piloto, atualizou o 
suplemento de acordo com as diretrizes G3 de 2006 e também desenvolveu protocolos para os indicadores. Ambas as fases incluíram consultas públicas, nas quais especialistas foram convidados a apresentar suas sugestões e comentários sobre a versão. Em março de 2010, foi lançada a versão final do suplemento na convenção Prospectors and Developers Association of Canada.

Tabela 1: Diretrizes econômicas específicas para o setor de mineração e metais

\begin{tabular}{|c|c|c|}
\hline Aspecto & & Indicador e Comentário \\
\hline $\begin{array}{l}\text { Desempenho } \\
\text { econômico }\end{array}$ & ECl & $\begin{array}{l}\text { - Comentário adicionado em pagamentos de } \begin{array}{llll}\text { uso } & \text { da } & \text { terra. } \\
\text { Comentário adicionado em Transparência das Indústrias Extrativas. }\end{array}\end{array}$ \\
\hline $\begin{array}{l}\text { Presença de } \\
\text { mercado }\end{array}$ & EC7 & $\begin{array}{l}\text { - Comentário adicionado para incluir parte da força de trabalho local, bem como na } \\
\text { gestão. }\end{array}$ \\
\hline
\end{tabular}

Fonte: GRI (2010b)

Conforme a Tabela 1, o suplemento inclui comentários nos aspectos desempenho econômico e presença de mercado.

Nas dimensões ambiental e social, além de diretrizes específicas para os indicadores, são incluídos aspectos de gestão. A Tabela 2 trata dos aspectos relacionados à dimensão ambiental. 
Tabela 2: Diretrizes ambientais específicas para o setor de mineração e metais

\begin{tabular}{|c|c|c|}
\hline Aspecto & & Comentário sobre aspecto de gestão \\
\hline $\begin{array}{l}\text { Emissões, efluentes } \\
\text { e resíduos }\end{array}$ & $\begin{array}{l}-\mathrm{C} \\
\mathrm{re}\end{array}$ & $\begin{array}{l}\text { nentário adicionado a fim de incluir nos relatórios questões setoriais específicas } \\
\text { tivas às emissões, efluentes e resíduos. }\end{array}$ \\
\hline Aspecto & & Indicador e comentário \\
\hline Materiais & EN2 & - Comentário adicionado para esclarecer o âmbito das definições de 'sucata'. \\
\hline \multirow{5}{*}{ Biodiversidade } & EN12 & $\begin{array}{l}\text { - Comentário adicionado para enfatizar o link para as atividades de reassentamento } \\
\text { e de encerramento. } \\
\text { - Compilação adicionada ao relatório sobre impactos na biodiversidade pelo } \\
\text { reassentamento ou de encerramento. }\end{array}$ \\
\hline & MM1 & $\begin{array}{l}\text { - Quantidade de terras (próprias ou arrendadas e administradas para atividades de } \\
\text { produção ou uso extrativo) perturbadas ou reabilitadas. }\end{array}$ \\
\hline & EN13 & - Compilação adicionada ao relatório sobre a compensação da biodiversidade. \\
\hline & EN14 & $\begin{array}{l}\text { - Comentário adicionado ao descrever a importância dos serviços dos } \\
\text { ecossistemas. } \\
\text { - Comentário adicionado à compilação de incluir nos relatórios informações sobre } \\
\text { serviços dos ecossistemas e abordagens. } \\
\text { - Definição acrescentada para os serviços de ecossistemas. } \\
\text { - Referências adicionadas. }\end{array}$ \\
\hline & MM2 & $\begin{array}{l}\text { - O número e a porcentagem total de locais identificados necessitando de um plano } \\
\text { de gestão da biodiversidade de acordo com critérios estabelecidos, bem como o } \\
\text { número (porcentagem) dos locais com planos em prática }\end{array}$ \\
\hline \multirow{4}{*}{$\begin{array}{c}\text { Emissões, efluentes } \\
\text { e residuos }\end{array}$} & EN20 & - Comentário adicionado a fim de incluir fontes móveis e fixas. \\
\hline & EN22 & - Comentário adicionado para esclarecer o âmbito de resíduos em relação à MM3. \\
\hline & MM3 & - Valores totais de sobrecarga, rochas, rejeitos e lamas e seus riscos associados. \\
\hline & EN23 & $\begin{array}{l}\text { - Comentário adicionado para esclarecer o âmbito de derrames. } \\
\text { - Compilação adicionada ao relatório sobre o resultado dos incidentes de } \\
\text { derramamento. }\end{array}$ \\
\hline
\end{tabular}

Fonte: GRI (2010b)

Na dimensão ambiental (Tabela 2), o suplemento inicialmente inclui um aspecto de gestão sobre emissões, efluentes e resíduos e também adiciona comentários referentes a materiais, biodiversidade e emissões, efluentes e resíduos. Além disso, são introduzidos três indicadores.

A seguir, na Tabela 3, são apresentadas as particularidades do suplemento relacionadas à dimensão social. 
Tabela 3: Diretrizes sociais específicas para o setor de mineração e metais

\begin{tabular}{|c|c|c|}
\hline Aspecto & \multicolumn{2}{|r|}{ Comentários sobre aspecto de gestão } \\
\hline Emprego & \multicolumn{2}{|r|}{$\begin{array}{l}\text { - Comentário adicionado a fim de incluir no relatório como as políticas, normas e práticas } \\
\text { serăo aplicadas aos empreiteiros }\end{array}$} \\
\hline 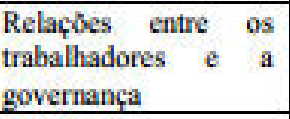 & \multicolumn{2}{|r|}{$\begin{array}{l}\text { - Comentário adicionado a fim de incluir no relatório informaçồes sobre a consulta dos } \\
\text { stakeholders nas relaçő́es de trabalho e governança }\end{array}$} \\
\hline $\begin{array}{l}\text { Saude e segurança no } \\
\text { trabalho }\end{array}$ & \multicolumn{2}{|r|}{ - Comentário adicionado ao relatório sobre a aplicaçâo da Convençẩo 176 da OIT } \\
\hline Direitos indigenas & \multicolumn{2}{|r|}{$\begin{array}{l}\text { - Comentário adicionado para incluir nos relatórios informaçôes sobre as políticas } \\
\text { relativas a consulta à comunidade e apoio }\end{array}$} \\
\hline $\begin{array}{l}\text { Planejamento } \\
\text { fechamento }\end{array}$ & \multicolumn{2}{|r|}{$\begin{array}{l}\text { - Comentário adicionado a fim de incluir informaçôes adicionais sobre o plano de } \\
\text { fechamento }\end{array}$} \\
\hline $\begin{array}{l}\text { Preparação para } \\
\text { Emerge̊ncia }\end{array}$ & \multicolumn{2}{|r|}{ - Comentário explicativo sobre preparação para emergências } \\
\hline Aspecto & \multicolumn{2}{|r|}{$\begin{array}{c}\text { Indicador e comentário } \\
\end{array}$} \\
\hline $\begin{array}{l}\begin{array}{l}\text { Relaçỏes entre } \\
\text { trabalhadores } \\
\text { governança }\end{array} \\
\end{array}$ & MM4 & - Número de greves e lock-outs com duraçăo superior a uma semana, por pais. \\
\hline $\begin{array}{l}\text { Saude e segurança no } \\
\text { trabalho }\end{array}$ & LA7 & entário adicionado em compilaçằo para incluir uma descriçẳo de acidentes \\
\hline \begin{tabular}{lr|}
$\begin{array}{l}\text { Liberdade } \\
\text { associaçăio } \\
\text { negociaçăo coletiva }\end{array}$ & $\mathrm{e}$ \\
\end{tabular} & HR5 & $\begin{array}{l}\text { - Comentário adicionado em compilação para relatar como a liberdade de } \\
\text { associação politica é implementada. }\end{array}$ \\
\hline Direitos indigenas & MM5 & $\begin{array}{l}\text { - Número total de operạ̧bes realizadas dentro ou próximo aos territórios dos } \\
\text { povos indigenas, e número e percentual das operaçő́es ou locais onde existem } \\
\text { acordos formais com povos indigenas. }\end{array}$ \\
\hline \multirow[t]{3}{*}{ Comunidade } & SO1 & $\begin{array}{l}\text { - Comentário adicionado a fim de descrever a importância da participação da } \\
\text { comunidade nos processos. } \\
\text { - Comentário para adicionar consideraçōes adicionais sobre compilação. } \\
\text { - Compilaçăoo acrescentada para incluir informaçỏes sobre inclusão social. } \\
\text { - Acrescentar definição de inclusăo social. } \\
\text { - Referência adicionadas. }\end{array}$ \\
\hline & MM6 & $\begin{array}{l}\text { - Número e descrição dos conflitos significativos em matéria de uso da terra, } \\
\text { direitos consuetudinários das comunidades locais e povos indigenas. }\end{array}$ \\
\hline & MM7 & $\begin{array}{l}\text { - Até que ponto os mecanismos de reclamą̧óes foram usados para resolver } \\
\text { disputas relacionadas ao uso da terra, os direitos consuetudinários das } \\
\text { comunidades locais e povos indigenas, e os resultados. }\end{array}$ \\
\hline $\begin{array}{l}\text { Mineração artesanal e } \\
\text { em pequena escala }\end{array}$ & MM8 & $\begin{array}{l}\text { - Número (e porcentagem) de locais de exploração da empresa, onde a mineração } \\
\text { artesanal e de pequena escala é realizada, ou locais adjacentes; os riscos e as } \\
\text { medidas tomadas para controlar e minimizar esses riscos. }\end{array}$ \\
\hline Reassentamento & MM9 & $\begin{array}{l}\text { - Locais onde ocorreram reassentamentos, o número de familias assentadas em } \\
\text { cada um, e como suas vidas foram afetadas no processo. }\end{array}$ \\
\hline $\begin{array}{l}\text { Planejamento } \\
\text { fechamento }\end{array}$ & MM10 & - Número e percentual de operaçठ̌es com planos de encerramento. \\
\hline Conformidade & SO8 & $\begin{array}{l}\text { - Comentário adicionado em decisð̌es relacionadas com as leis de segurança, } \\
\text { saúde e trabalho. }\end{array}$ \\
\hline Manejo de materiais & MM11 & - Programas e os progressos relativos ã administração de materiais. \\
\hline
\end{tabular}

Fonte: GRI (2010b)

Na dimensão social (Tabela 3), são incluídos aspectos de gestão referentes a emprego, relações entre os trabalhadores e a governança, saúde e segurança no trabalho, direitos indígenas, planejamento de fechamento, preparação para emergências. Além disso, o suplemento inclui oito indicadores e comentários adicionais nas dimensões relações entre os trabalhadores e a governança, saúde e segurança no trabalho, liberdade de associação e negociação coletiva, 
direitos indígenas, comunidade, mineração artesanal e em pequena escala, reassentamento, planejamento de fechamento, conformidade, manejo de materiais.

O Instituto Ethos (2003) desenvolveu um suplemento dos seus indicadores de responsabilidade social empresarial para o setor de mineração, abordando os seguintes aspectos:

1. Valores e transparência: avaliação com relação ao diálogo com as partes interessadas no que se refere aos impactos ambientais e sociais das atividades da empresa;

2. Público interno: cuidados com saúde, segurança e condições de trabalho para os funcionários;

3. Meio ambiente: gerenciamento do impacto ambiental, dispondo de planos de contingência e de fechamento da mina; cuidados com energia, água, emissões/resíduos, vazamentos, uso do solo, biodiversidade, níveis de radiação;

4. Fornecedores: relações com fornecedores terceirizados de modo a assegurar que os padrões ambientais, de saúde e segurança adotados pela empresa sejam cumpridos;

5. Comunidade: gerenciamento do impacto da empresa na comunidade do entorno;

6. Governo e sociedade: comprometimento da empresa com a sustentabilidade social.

Os indicadores setoriais do Instituto Ethos buscam fornecer um diagnóstico preciso da realidade empresarial de modo a abranger as peculiaridades do setor e são complementares aos indicadores Ethos gerais (INSTITUTO ETHOS, 2003).

Conforme demonstrado, muitas são as questões a serem observadas no desenvolvimento de indicadores de sustentabilidade para a indústria mineral, porém é importante ressaltar que as peculiaridades do setor devem ser consideradas no sentido de que as informações fornecidas reflitam de forma fidedigna a posição da empresa no que se refere à sustentabilidade. 
estudo de Jenkins e Yakovleva (2006) analisou a divulgação e as questões sociais e ambientais na indústria de mineração em dez maiores empresas do setor no mundo. O estudo revelou que os relatórios das empresas pesquisadas estão abrangendo questões mais complexas relacionadas à sustentabilidade e à responsabilidade social, indicando maturação crescente de estratégias e políticas mais abrangentes de responsabilidade social. No entanto, a pesquisa evidenciou uma variabilidade no que refere à maturidade das empresas na divulgação social e ambiental, em termos de sofisticação de relatórios, desenvolvimento de políticas e tipos de métricas utilizadas. A investigação demonstrou que os meios de comunicação para a divulgação social e ambiental no setor de mineração ainda está evoluindo, tanto por parte das empresas como do setor em geral.

A divulgação das ações sociais e ambientais é primordial para que a indústria mineral melhore a sua imagem perante a sociedade e também em virtude da valorização pelos investidores de posturas empresariais preocupadas com questões sociais, ambientais e éticas (JENKINS e YAKOVLEVA, 2006).

Pode-se observar, nas iniciativas que visam contribuir para a sustentabilidade da mineração, a grande importância dada aos aspectos ambientais e sociais e a menor importância dada a questão econômica. Isso se justifica pela necessidade de mudança cultural que precisa ser promovida, em que o retorno ao acionista deve ser tão importante como os impactos socioambientais que seu empreendimento gera.

No entanto, se o aspecto econômico for colocado em segundo plano, simplesmente onerando o empreendimento mineral com ações de proteção socioambiental e reduzindo o retorno financeiro sobre o investimento, a atratividade da mineração será afetada, gerando impactos sociais de grandes proporções.

A saída para esse impasse passa pelo ponto citado em uma famosa frase de Albert Einstein "Insanidade é continuar fazendo sempre a mesma coisa e esperar resultados diferentes", ou seja, é necessário inovar. No caso da mineração, que é uma indústria de capital intensivo e elevado risco, a inovação necessita ser mais abrangente, promovendo mais rentabilidade ao investidor, menos impactos ambientais e mais contribuição para o desenvolvimento da sociedade. 


\section{Mineração e Desenvolvimento Sustentável: Desafios para o Brasil}

No documento desenvolvido em 2001 pelo MCT e CETEM, "Mineração e Desenvolvimento Sustentável" podem ser destacados como principais desafios a serem enfrentados pelo setor, sem preocupação de estabelecer prioridades:

1) A participação da sociedade civil nos processos decisórios e gerenciais no nível das políticas públicas, tanto minerais como ambientais, ainda é muito incipiente. Essa situação, também, se reflete no nível do empreendimento mineral, ou seja, a comunidade não participa das decisões relacionadas ao processo de instalação e não acompanha as diversas etapas da evolução do empreendimento e do seu fechamento. A grande maioria dos projetos de mineração não é gerada localmente, acabando por ser considerados pela população como projetos externos ou enclaves.

Para tanto, urge criar instrumentos que: viabilizem a efetiva participação; promovam a capacitação dessas comunidades e permitam 0 acesso à informação. O Planejamento Estratégico Participativo é exemplo de um instrumento indispensável, para qualquer empreendimento mineral, seja ele de grande, médio ou pequeno porte e, em qualquer das suas fases, inclusive, para a de fechamento da mina. Tal planejamento deverá viabilizar a discussão clara e transparente com as comunidades locais.

2) A regulamentação incidente sobre o setor, tanto a ambiental como a mineral, é de difícil identificação, apreensão, aplicação e, em muitos casos, conflitantes. A outorga do licenciamento ambiental é muito demorada, motivada pela burocratização do processo, duplicação de funções entre os diferentes órgãos e ausência de pessoal devidamente treinado para concedê-lo. Um processo de aperfeiçoamento, tanto da legislação como das estruturas existentes, deve ser levado a cabo. Programas de capacitação tornam-se urgentes. Necessário, também, se torna otimizar a legalização do empreendimento mineral pela simplificação dos processos e diminuição do número de órgãos licenciadores.

A comunicação e a articulação entre esses órgãos públicos reguladores, sejam eles ambientais ou específicos do setor mineral, constituem-se uma tarefa nem sempre fácil, mas necessária, devendo-se concretizar não somente na vontade 
política, mas também na concepção e composição dos atuais órgãos ou daqueles a serem criados em nível setorial.

3) São muitos os órgãos que fiscalizam o setor mineral, todos eles com deficiências de capacitação no que diz respeito a infraestrutura e a pessoal. Verifica-se que existe um sério problema de informalidade no setor mineral, particularmente relacionado às pequenas empresas, além da carência de monitoramento e fiscalização da saúde ambiental. Sem dúvida alguma, uma fiscalização eficiente, em todos os sentidos, deverá ser efetivada, de maneira a propiciar, dentre outras condições, um ambiente de concorrência mais igualitário entre as mineradoras. Para tanto, a capacitação de técnicos dos órgãos públicos envolvidos na questão deverá ser incentivada e posta em prática.

4) O Zoneamento Ecológico-Econômico - ZEE tem sido usado como instrumento de política ambiental pelo governo brasileiro para subsidiar as decisões de planejamento socioeconômico-ambiental do desenvolvimento e do uso do território nacional em bases sustentáveis. Ele diagnostica de maneira integrada as potencialidades e as vulnerabilidades naturais, sociais e culturais, bem como prognostica quanto ao uso do território, prevendo em todo o processo a participação do governo, setor privado, ONGs e sociedade civil. Entretanto, nos últimos 10 anos, somente em $11 \%$ do território foi efetivamente realizado o referido zoneamento.

Inserir a mineração na questão do ZEE é crucial, como o de contemplar, também, a mineração nos contextos dos comitês de bacias, nos planos diretores das regiões metropolitanas e municipais, bem como em outros instrumentos nos quais ela se encontra ausente.

5) O Brasil possui uma série de ecossistemas e recursos naturais que devem ser protegidos, conciliando preservação e desenvolvimento. Por outro lado, detém algumas áreas social e culturalmente sensíveis, como as chamadas áreas ou terras indígenas, nas quais não está sendo permitida a execução de novos projetos de mineração, até que sejam regulamentados os preceitos constitucionais. Os índios brasileiros, de maneira geral, não são contra a mineração em suas áreas, entretanto, são unânimes em afirmar que, quando ela ocorrer, querem participar do processo decisório, desde a sua implantação até o seu fechamento (Planejamento Estratégico Participativo). O tema da mineração 
em áreas indígenas e de conservação deverá, pois, ser enfrentado em todas as suas dimensões.

6) Há necessidade de gerar e disseminar novas tecnologias, principalmente, as chamadas tecnologias limpas e sustentáveis para qualquer tipo de empreendimento, seja pequeno, médio ou grande. Essas devem responder aos grandes desafios do setor: minimização energética; minimização do uso dos materiais; minimização do impacto ambiental e maximização da satisfação social. Alguns exemplos mais específicos podem ilustrar melhor a tarefa que se tem pela frente, como a disposição e a utilização dos rejeitos; o tratamento e o descarte de afluentes; o aumento da eficiência do aproveitamento dos bens minerais, bem como a criação de oportunidades de inserção dos rejeitos gerados na matriz produtiva; e a agregação de valor aos produtos de origem mineral são desafios a serem enfrentados. Identificar e divulgar as experiências bem sucedidas aparece como um aspecto importante. Salienta-se que, em recente congresso de trabalhadores da mineração, foi criado o Programa Mineração Social, que se preocupa em pensar o bem mineral como seu ciclo de vida. Iniciativas como esta indicam o caminho que se deve trilhar.

7) De acordo com as estatísticas, os trabalhadores do setor formal apresentam, em termos nacionais, o mais elevado índice de mortalidade e incapacidade permanente. Esse fato atesta que as condições de trabalho têm sido relegadas a um segundo plano. Há necessidade de se estudar o problema para verificar, entre outras, a sua origem, a amplitude, bem como permitir avaliar efetivamente esse impacto social. A OHS 18000 (Occupational Health and Safety), que contempla a saúde e a segurança do trabalhador, poderá contribuir para transformar esse quadro negativo para além das Normas Reguladoras de Mineração - NRM-22 - Proteção ao Trabalhador.

8) A imagem da mineração é negativa, levando ao desgaste e conflito com a sociedade civil, devido, entre outros fatores, à complexidade na compreensão dos benefícios da mineração, à percepção imediata dos aspectos negativos, às práticas inadequadas e mesmo predatórias de algumas minerações e, principalmente, à repercussão negativa dos acidentes ambientais e de trabalho. Para reverter esse quadro, a relação entre setor mineral e sociedade civil deverá ser revolucionada. O setor mineral brasileiro precisa passar de uma linha de ação 
passiva para uma ativa no seu relacionamento com a sociedade. Nesse sentido, auscultar a sociedade e promover uma política de portas abertas são aspectos que devem ser enfrentados. O governo deverá criar estâncias permanentes de participação na definição das políticas, legislação e fiscalização. E a sociedade civil deverá se capacitar e organizar-se para efetivamente poder contribuir com esse processo.

9) Esforços estão sendo empreendidos no sentido de melhorar em termos quantitativos e qualitativos a informação e seu acesso, entretanto, em todos os níveis e esferas, esse processo ainda é deficiente. A informação é vital para todos os segmentos e atores do setor, inclusive, para a participação da sociedade civil. Gerar dados primários e indicadores, criar e/ou aperfeiçoar os bancos de dados existentes, tornando-os amplos e indiscriminadamente acessíveis a todos os interessados do setor mineral, é tarefa urgente.

10) No que diz respeito à pequena mineração, o Brasil possui um imenso universo que é bastante diversificado, abrangendo grande parte dos minerais. $O$ segmento da pequena empresa se concentra principalmente nos minerais de uso direto na construção civil. Outro segmento da pequena mineração é o do garimpo, que abrange os chamados depósitos garimpáveis. Em ambos os segmentos, a informalidade é grande. Enfatizando-se que, no setor de agregados, apresenta-se um problema adicional, que é a mineração em áreas urbanas, potencializando os problemas sociais e de degradação ambiental.

Aparecem como desafios para ambos os segmentos: a legalização, a simplificação dos processos de atribuição dos títulos minerários e do licenciamento ambiental, os instrumentos e os programas de apoio técnico a essas minerações e um acurado estudo geológico.

11) O tema fechamento de minas é novo, tanto no Brasil como no mundo. $O$ setor mineral necessita enfrentá-lo. Em determinadas regiões, por exemplo, a ausência de tratamento da questão dificultou o fechamento racional das minas existentes, gerando conflitos e impactos socioeconômicos e ambientais altamente prejudiciais à comunidade local. Alguns aspectos apresentam-se prioritários, como a elaboração de normas para instituir garantias reais para a recuperação, de procedimentos e processos de licenciamento e de planos de fechamento que contemplem os diversos interesses e expectativas. 
12) Considerando que a série ISO já se transformou em um diferencial de competitividade e algumas delas (a série ISO 14.000, por exemplo) se constituem em uma realidade para poucas empresas, através de um processo de que não participa grande parte do setor, há necessidade de se criarem mecanismos institucionais independentes que gerem entidades certificadoras do setor empresarial, com critérios de sustentabilidade (social, econômica, ambiental, educacional e cultural).

Com base nos desafios identificados para o futuro da mineração brasileira, a proposta de uma operação-piloto sustentável com introdução de inovações e integração regional poderá auxiliar na sustentabilidade dos empreendimentos minerais em vários aspectos:

1. Elevação da rentabilidade por meio de otimização de investimentos, melhoria no desempenho operacional, redução do consumo energético e aproveitamento do bem mineral, contribuindo para competitividade do empreendimento e a longevidade do negócio;

2. Melhoria na avaliação dos impactos socioambientais por meio de uma relação mais transparente com os órgãos ambientais e com a comunidade local.

3. Contribuição mais ampla para o desenvolvimento regional por meio da integração com a comunidade local.

\subsection{Competitividade da Mineração Brasileira}

A economia brasileira é pouco competitiva, ocupando a 54a posição entre as 60 economias analisadas no Índice de Competitividade Mundial (World Competitiveness Yearbook), do International Institute for Management Development (IMD) (Portal Brasil, 2013). A baixa competitividade também é observada na indústria brasileira que, de acordo com a FIESP, ocupa a $37^{\text {a }}$ posição no ranking de competitividade industrial $(R 7,2013)$, fato este reforçado pelo estudo efetuado pela ABIMAQ e resumido na Tabela 4. 
US\$ FOB - Jan-Ago 2010

\begin{tabular}{|c|c|c|c|c|}
\hline NCM & Descrição & Brasil* $^{*}$ & Alemanha** & China** \\
\hline 8481.8093 & Válvula tipo gaveta & 53,30 & 35,08 & 4,95 \\
\hline 8457.1000 & Centro de usinagem & 34,07 & 22,94 & 9,75 \\
\hline 8414.4010 & $\begin{array}{l}\text { Compressores de ar montados sobre } \\
\text { chassis com rodas e robocáveis de } \\
\text { deslocamento alternativo }\end{array}$ & 39,84 & 32,27 & 2,27 \\
\hline 8425.11 .00 & $\begin{array}{l}\text { Talhas, cadernais e moitões de } \\
\text { motor elétrico }\end{array}$ & 53,46 & 20,18 & 2,76 \\
\hline 8454.3010 & Máquinas de moldar sob pressão & 29,29 & 13,65 & 4,92 \\
\hline 8562.2100 & $\begin{array}{l}\text { Máquinas para enrolar, arquear, } \\
\text { dobrar, endireitar ou aplainar de } \\
\text { comando numérico }\end{array}$ & 20,80 & 28,59 & 3,00 \\
\hline
\end{tabular}

Este estudo é um exemplo claro que a indústria brasileira precisa urgentemente se reinventar, pois seus produtos são em média $44 \%$ mais caros que os alemães e americanos e incomparavelmente mais caros que os chineses. A ABIMAQ também levantou as causas das diferenças de custo de produção nacional em relação aos países desenvolvidos, como pode ser observado na Tabela 5.

Tabela 5: Diferencial de Custo na Produção Nacional em Relação aos Concorrentes Internacionais (ABIMAQ, 2011)

\begin{tabular}{|lc|}
\multicolumn{1}{|c|}{ Componentes do Custo Brasil } & $\begin{array}{c}\text { Aumento de custos } \\
\text { em ponto } \\
\text { percentual da RL }\end{array}$ \\
\hline 2 Custo Brasil & $\mathbf{4 3 , 8 5}$ \\
\hline 2.1 Impostos não recuperáveis na cadeia produtiva & 2,98 \\
\hline 2.2 Encargos sociais e trabalhistas & 3,99 \\
\hline 2.3 Logística (1) & 1,90 \\
\hline 2.4 Impacto dos juros sobre capital de giro & 9,41 \\
\hline 2.5 Burocracia e custos de regulamentação & 0,40 \\
\hline 2.6 Custos de investimento & 1,16 \\
\hline 2.7 Custos dos insumos básicos (2) & 24,01 \\
\hline 2.8 Custos de energia (2) & 0,00 \\
\hline (1) Comparativo com Estados Unidos; (2) Comparativo com Alemanha e EUA.
\end{tabular}

Pode-se observar aqui que as duas principais causas correspondem a mais de $75 \%$ da diferença e que, ao contrário do discurso dominante, a responsabilidade pode ser muito mais do empresariado do que do governo. Como exemplo, podese citar o fato de as empresas declararem que o problema de juros sobre o capital de giro está mais associado ao elevado volume de estoques (matérias- 
primas, produtos intermediários e acabados e peças de reposição), decorrentes de ineficiências em seus processos, do que propriamente das taxas de juros.

No entanto, a mineração brasileira parece estar indo muito bem, o valor da produção mineral brasileira (Figura 1) e o saldo da balança comercial mineral (Figura 2) têm crescido fortemente nos últimos anos, sendo que o minério de ferro é o que mais contribui para esses resultados, pois é responsável por $80 \%$ das exportações minerais brasileiras (Figura 3) (IBRAM, 2012).

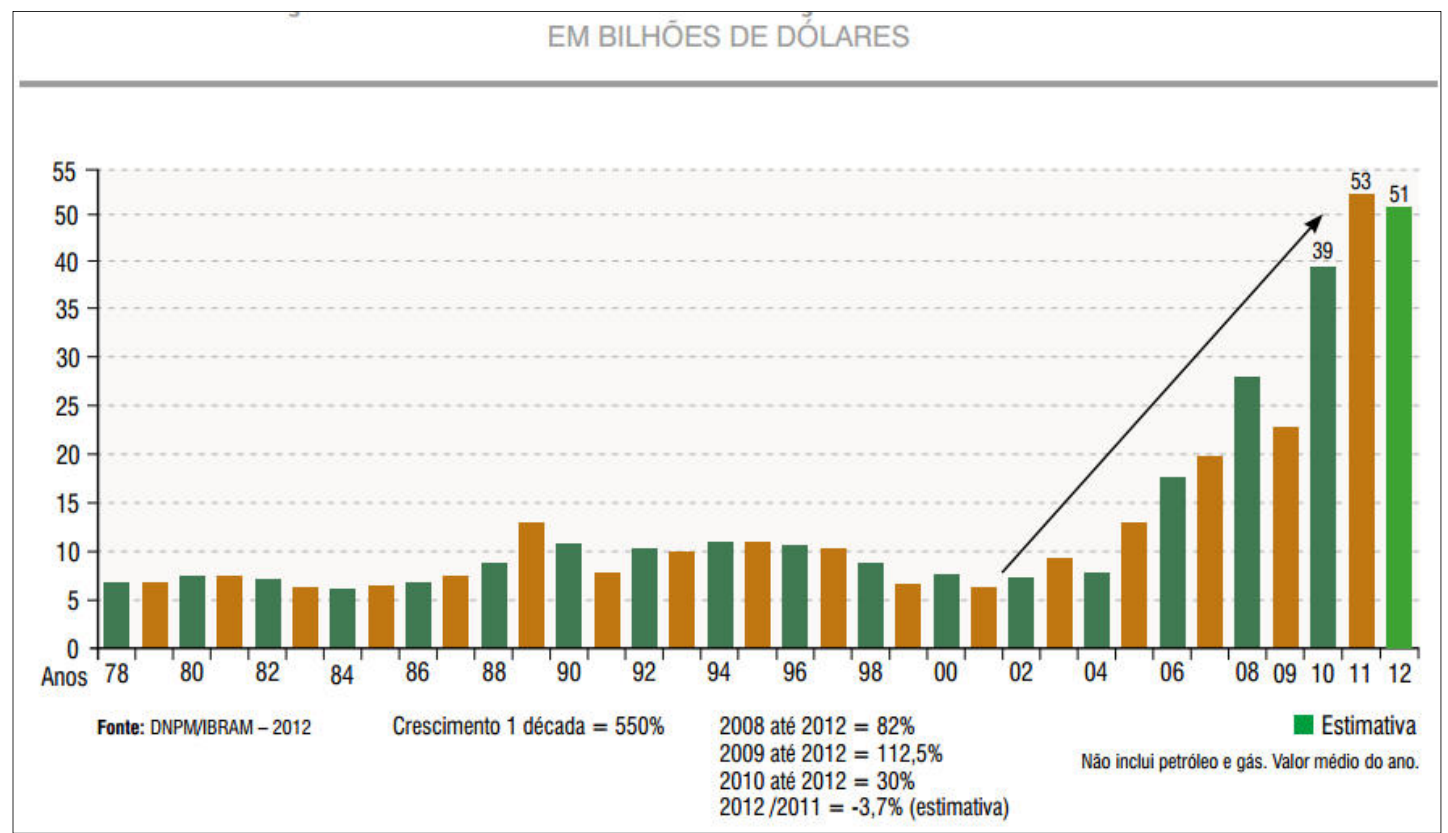

Figura 1: Evolução do Valor da Produção Mineral Brasileira (DNPM/IBRAM, 2012)

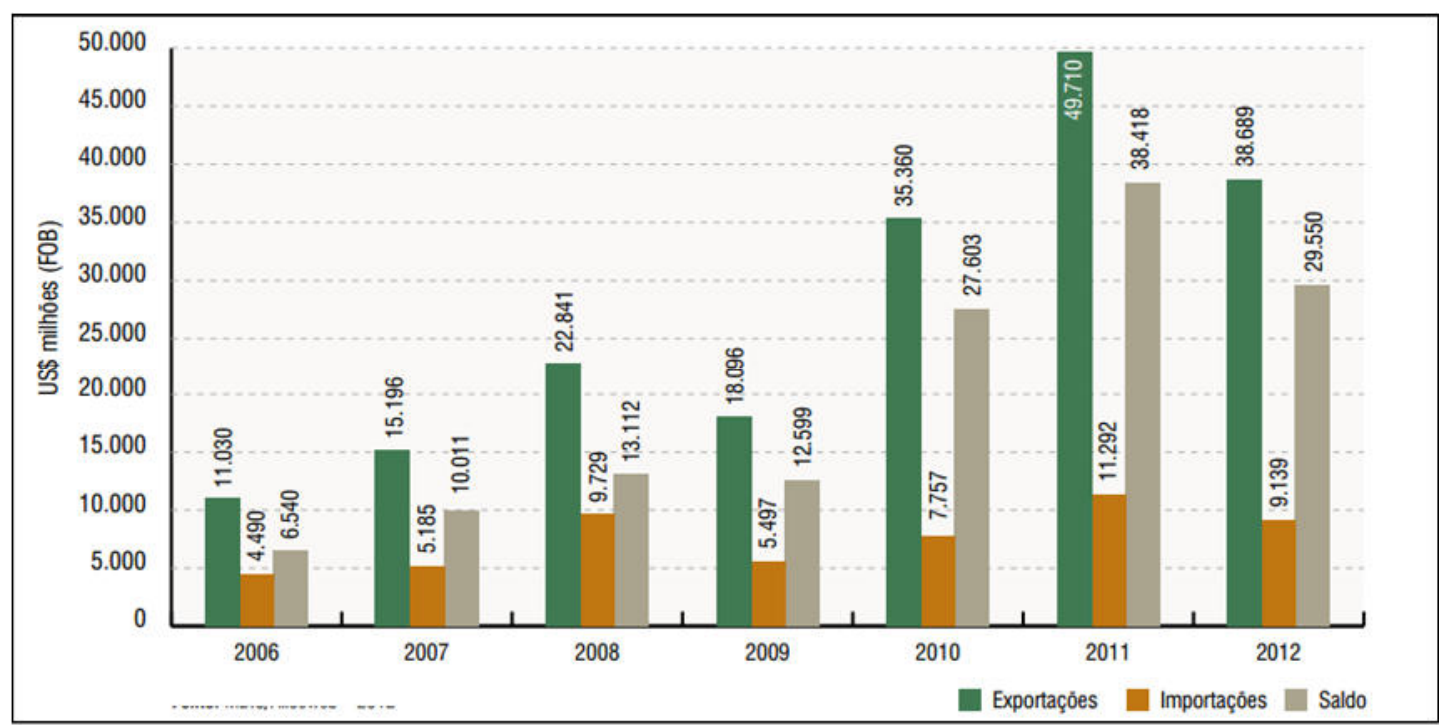

Figura 2: Evolução Balança Comercial Mineral Brasileira (MDIC, 2012) 


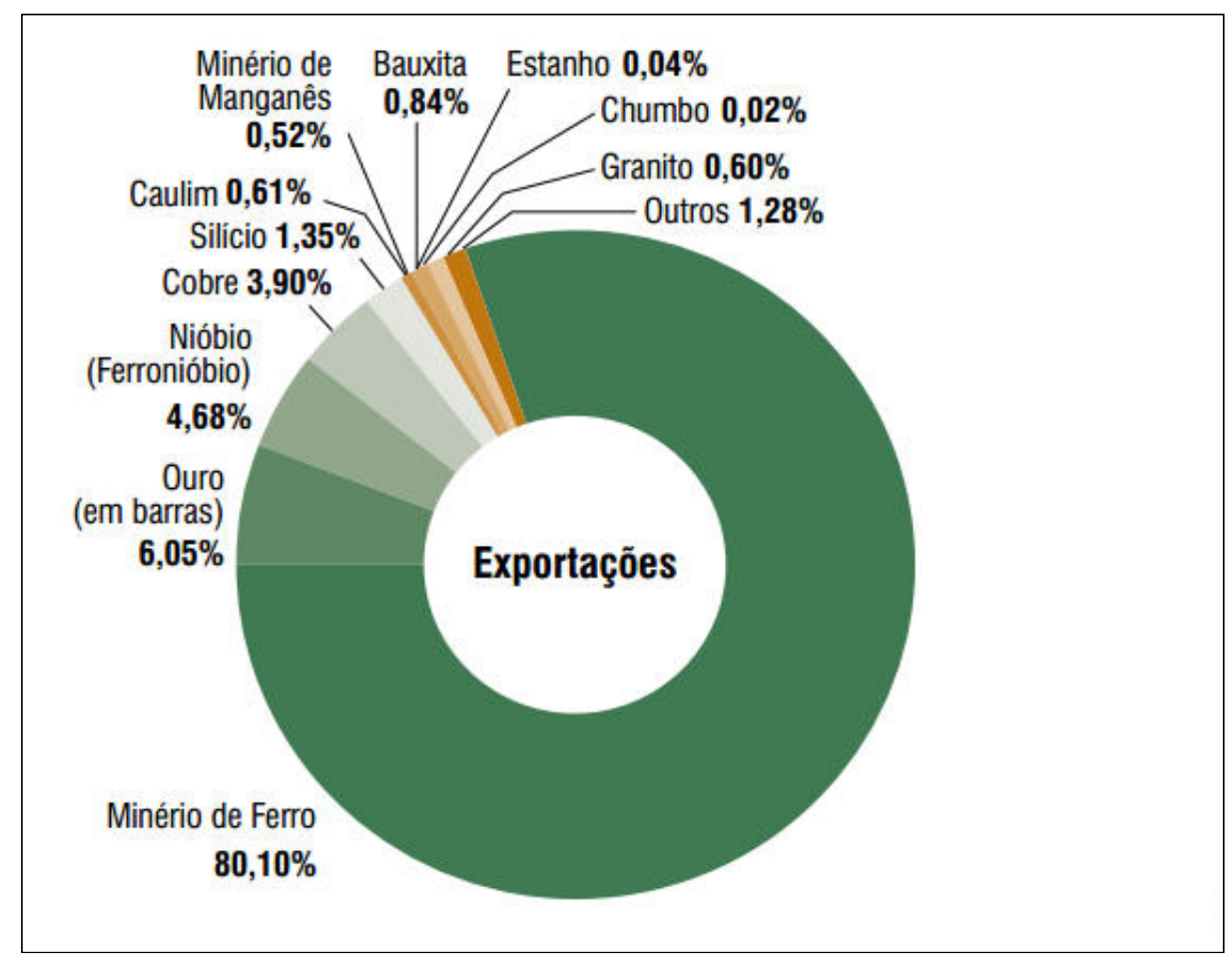

Figura 3: Exportações Minerais Brasileiras em 2012 (MDIC, 2012)

Apesar desses resultados, a mineração brasileira tem perdido competitividade nos últimos anos, isso pode ser constatado pelo fato de o Brasil ter deixado de ser o principal exportador de minério de ferro em 2003, perdendo a posição para a Austrália que, em 2000 , possuía $27 \%$ de participação no mercado e subiu para $40 \%$ em 2008, enquanto que, nesse mesmo período, o Brasil caiu de $33 \%$ para 25\%, conforme mostra a Figura 4 (PAIS et al., 2012). 


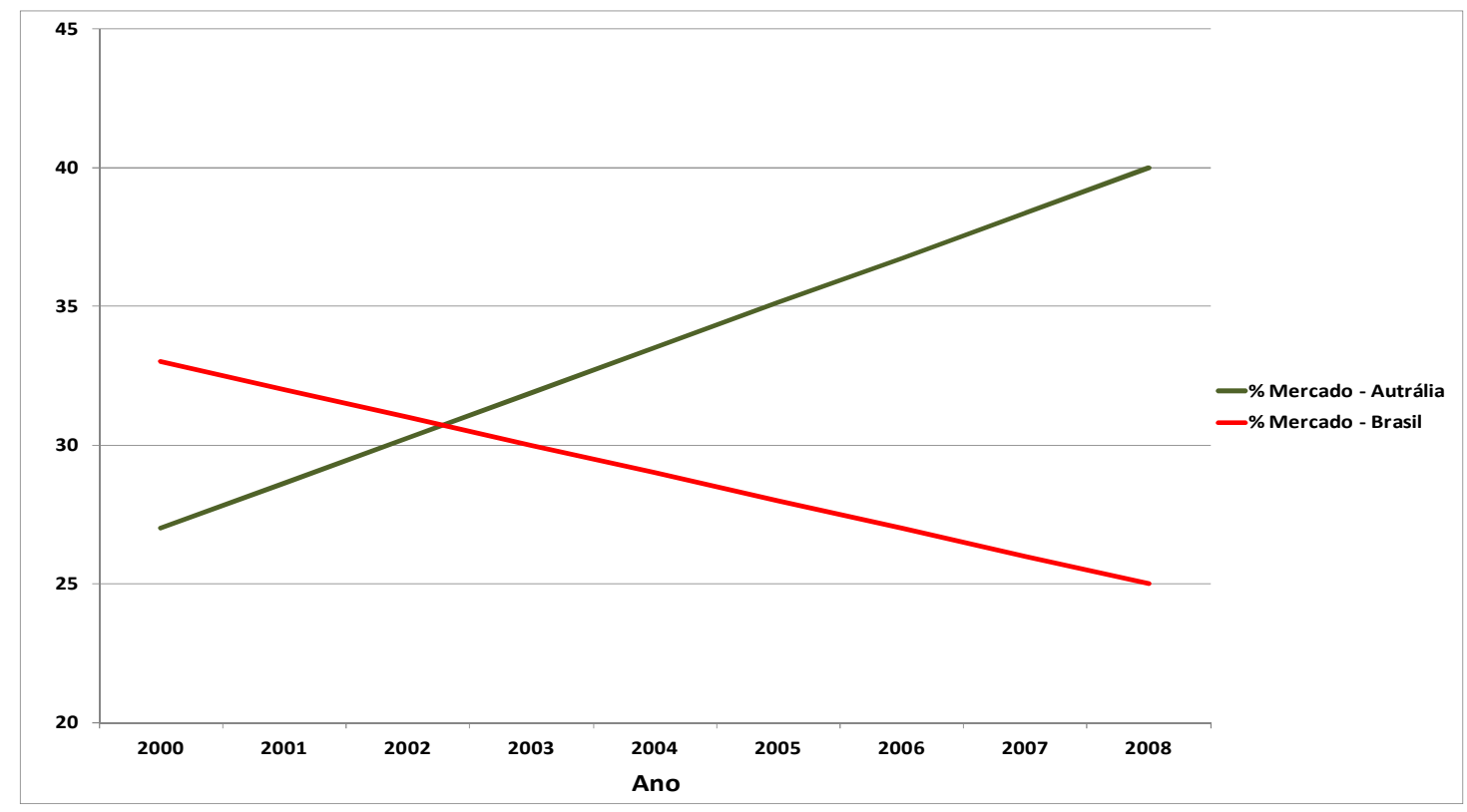

Figura 4: Comparativo Mercado Minério Ferro Brasil e Austrália

FONTE: PAIS, et al., 2012.

Segundo Menezes (2012), o problema está na produtividade da indústria brasileira. Como mostra a Figura 5, a produtividade do trabalho na indústria de transformação brasileira cresceu entre 1965 e 1980, mas declinou continuamente nos anos 80, e, após um breve aumento no início da década de 90 (provocado pela liberalização comercial), esteve estagnada desde então. Enquanto isso, a produtividade do trabalhador industrial americano vem aumentando continuamente desde 1965, o mesmo acontecendo com o coreano que ultrapassou o brasileiro no início da década de 90. Isso afeta diretamente a participação da indústria no PIB e nas exportações.

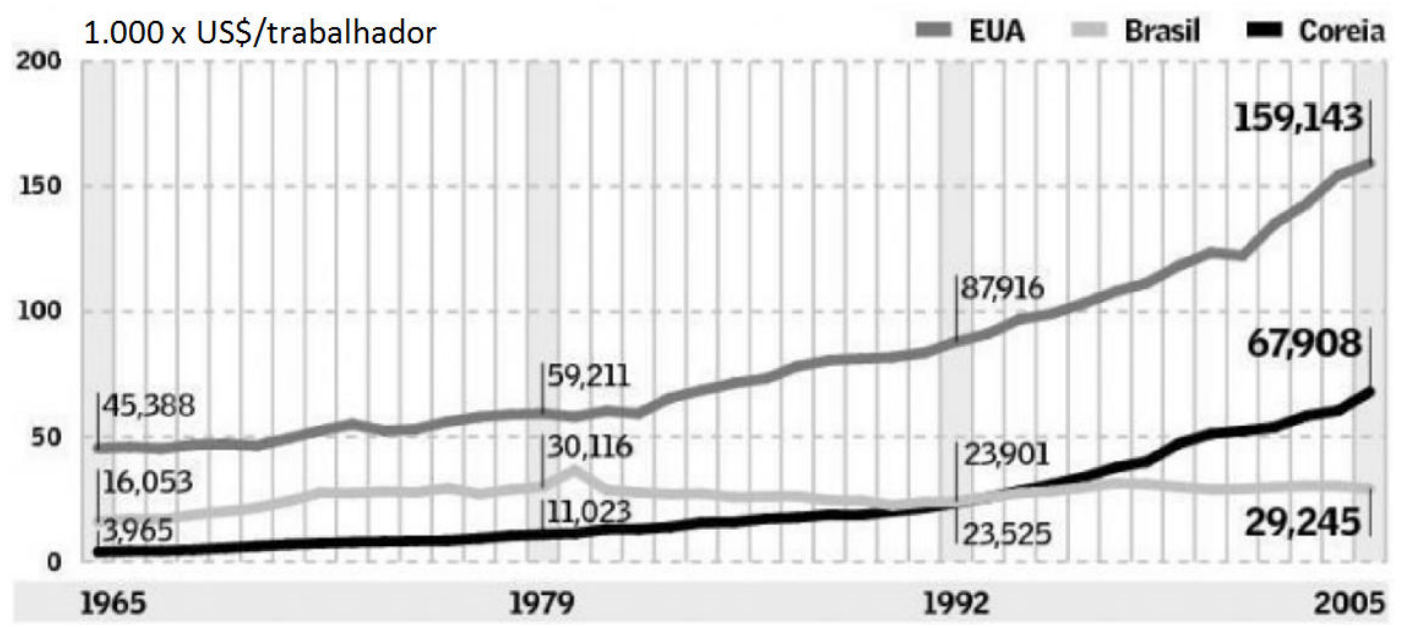

Figura 5: Evolução da Produtividade da Indústria de Transformação Brasileira 
Ainda segundo Menezes (2012), uma parte dos empresários brasileiros parece mais preocupada em fazer lobby no governo e na mídia do que em aumentar sua produtividade. Nas últimas décadas, o investimento em capital físico e a taxa de inovações tecnológicas na indústria foram pífios. Além disso, ele afirma que as técnicas gerenciais utilizadas por grande parte das empresas industriais brasileiras são bastante ultrapassadas.

Para Lins (2013) a situação da mineração de ferro brasileira é ainda mais grave, como mostram as figuras 6 e 7.

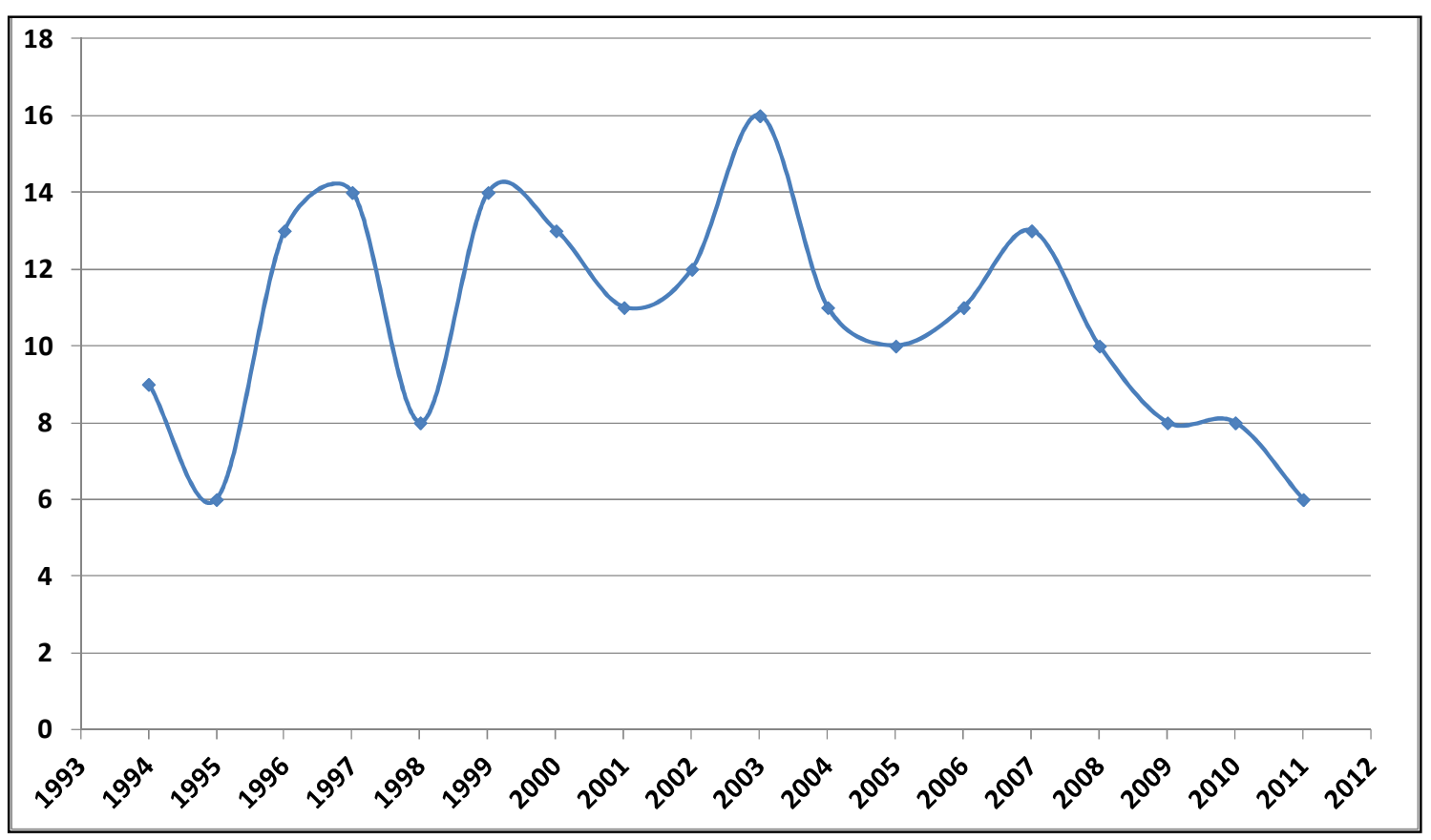

Figura 6: Produtividade da Mineração Brasileira de Ferro (mil t/empregado/ano)

FONTE: LINS, 2013. 


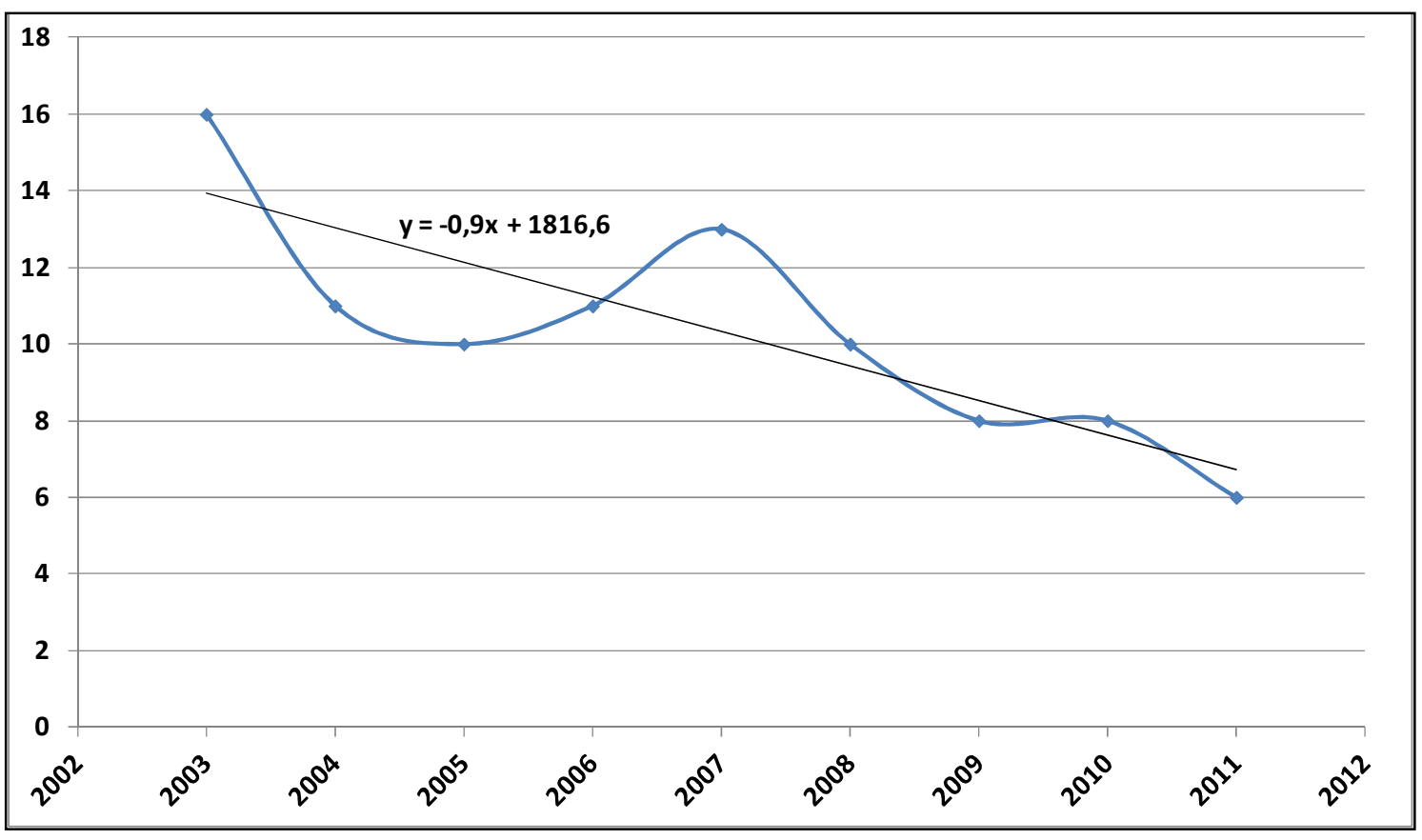

Figura 7: Produtividade da Mineração Brasileira de Ferro (mil t/empregado/ano)

FONTE: LINS, 2013.

Na Figura 6 observa-se que a produtividade da mineração de ferro de 2012 é igual da 1995 e na Figura 7 que a partir de 2003 a queda foi de aproximadamente $10 \%$ ao ano.

É notório saber que, com recursos escassos, as empresas desenvolvem projetos menos consistentes e mais tradicionais, transferindo os investimentos para custos operacionais e riscos, que, no caso da mineração, poderão ser extremamente prejudiciais em longo prazo.

O incremento de inovações na mineração brasileira irá contribuir para o desenvolvimento de um modelo mais sustentável, baseado em desenvolvimento tecnológico e inovações, trazendo redução de impactos, mais contribuição para o desenvolvimento regional e ganho de competitividade para o setor mínerometalúrgico em curto prazo e, como a mineração e a siderurgia estão na base da indústria que sustenta o desenvolvimento do Brasil (DELOITTE, 2012), esse modelo poderá ser transmitido para o setor industrial brasileiro de modo geral no médio e longo prazo. Dessa forma, o desenvolvimento e a disseminação de uma nova abordagem para o desenvolvimento de projetos minerais que contribua para a evolução da indústria mineral nacional e para a mudança cultural, 
fortalecendo parcerias e aproximando as empresas da academia, são de grande valia para toda a sociedade brasileira.

A FIESP aponta como principais obstáculos para uma maior competitividade da indústria brasileira fatores como o efeito cambial sobre as exportações, a alta carga tributária, as elevadas taxas de juros e a falta de mão de obra qualificada (R7, 2012). Por outro lado, uma pesquisa coordenada pela Fundação Dom Cabral aponta que fatores, como o frágil crescimento econômico do produto interno, a baixa produtividade de suas indústrias e as pressões inflacionárias, acabaram por combalir, nos últimos anos, a competitividade brasileira (PORTAL BRASIL, 2012).

Dessa forma, espera-se que as empresas de mineração que atuam no Brasil invistam em inovação de sustentabilidade, aumentem sua produtividade, reduzam custos e impactos ambientais, agreguem valor aos seus produtos, capacitem sua mão de obra e contribuam para o desenvolvimento regional. Com isso, é possível reduzir a carga tributária e obter financiamentos com menores taxas, atacando os principais problemas apontados pela FIESP (2012) e pela pesquisa da Fundação Dom Cabral (2012), contribuindo para que essas empresas ganhem competitividade.

Na publicação "Brasil Competitivo - Desafios e estratégias para a indústria da transformação" (DELOITTE, 2012), foi efetuado o seguinte comentário: "Como base fundamental da indústria manufatureira, a mineração e a siderurgia podem, juntas, a partir de uma atuação mais cooperativa entre si, enfrentar melhor seus desafios e ampliar ainda mais o seu papel no desenvolvimento do País".

O Brasil é o país com maior potencial mineral do mundo, alcançando a maior pontuação entre todos os outros países e regiões do planeta. Segundo o Fraser Institute, o potencial brasileiro supera o de outros países importantes em mineração, como Canadá, Estados Unidos e Austrália (IBRAM, 2007). No entanto, esse potencial ainda está longe de ser aproveitado na sua totalidade. Normalmente, todo novo depósito mineral necessita de pesquisa tecnológica para sua efetiva caracterização e para a definição de rotas de processo para a viabilização de sua exploração, mas, em alguns casos, é necessário também o 
desenvolvimento de novas tecnologias de forma incremental ou mesmo inovações radicais. Esses processos podem ser facilitados por meio da utilização dos financiamentos e incentivos fiscais citados anteriormente, ou seja, novos empreendimentos minerais podem, em alguns casos, serem desenvolvidos como projetos de inovação, aproveitando os incentivos associados, reduzindo os riscos financeiros e facilitando a viabilização de projetos minerais consistentes, com menores riscos ambientais e com mais contribuição para o desenvolvimento regional.

Além disso, a mineração brasileira, apesar de ser competitiva em vários setores, possui desempenho bem abaixo do seu potencial, poderia apresentar resultados muito mais efetivos se se promovessem inovações aplicadas às suas demandas e mais alinhadas às condições e à realidade cultural do país, tornando o setor muito mais competitivo.

O governo brasileiro está ciente da necessidade de modernização e de ganho de competitividade da indústria brasileira e gerou as condições estruturais para fomentar o desenvolvimento de inovações nas empresas estabelecidas no país. Esse fomento está associado a financiamento subsidiado e incentivos fiscais.

Existem linhas de financiamento subsidiado para inovação em instituições do governo como BNDES e FINEP. Elas possuem taxas inferiores à inflação, prazos de carência e amortização acima das linhas tradicionais oferecidas no mercado.

De acordo com uma reportagem do Jornal Valor Econômico, os incentivos para inovação no Brasil estão no mesmo nível ou acima de muitos países que são reconhecidamente inovadores. Isso pode ser observado na Tabela 7 que apresenta um quadro comparativo dos incentivos oferecidos em alguns países. 
Tabela 6: Comparativo de Incentivos Internacionais para P\&

\begin{tabular}{|l|r|r|l|}
\hline \multicolumn{1}{|c|}{ País } & Mínimo & Máximo & \multicolumn{1}{|c|}{ Observação } \\
\hline Austrália & $45 \%$ & $45 \%$ & $\begin{array}{l}\text { Créditos tributários reembolsáveis para empresas pertencentes a grupos } \\
\text { com receita até 20 milhões de dólares australianos }\end{array}$ \\
\hline Canadá & $20 \%$ & $40 \%$ & Crédito de Imposto de Renda das despesas correntes e de capital em P\&D \\
\hline Reino Unido & $130 \%$ & $175 \%$ & $\begin{array}{l}\text { Combina deduções adicionais de impostos com créditos potencialmente } \\
\text { restituíveis }\end{array}$ \\
\hline Holanda & $30 \%$ & $50 \%$ & $\begin{array}{l}\text { A empresa pode deixar de transferir ao fisco holandês uma parte do } \\
\text { imposto de renda retido sobre os salários de parte de seus empregados da } \\
\text { área de P\&D }\end{array}$ \\
\hline França & $54 \%$ & $68 \%$ & $\begin{array}{l}\text { Oferece um crédito de imposto de renda equivalente a 30\% dos primeiros } \\
\text { em um ano e 5\% sobre o que ultrapassar o valor }\end{array}$ \\
\hline Brasil & $\begin{array}{l}\text { Incentivos fiscais da Lei do Bem para empresas que trabalhem em regime } \\
\text { de lucro real }\end{array}$ \\
\hline
\end{tabular}

FONTE: Valor Econômico - 07/06/2010.

No entanto, a mineração é o setor que menos utilizou os incentivos fiscais para inovação tecnológica associados à Lei do Bem, conforme observa-se na Tabela 8 (MCT\&I, 2012).

Tabela 7: Incentivos Fiscais para Investimentos em PD\&I por Setor

\begin{tabular}{|c|c|c|c|c|c|c|c|c|c|c|c|c|}
\hline \multirow{3}{*}{ Setores } & \multirow{2}{*}{\multicolumn{2}{|c|}{2006}} & \multirow{2}{*}{\multicolumn{2}{|c|}{2007}} & \multirow{2}{*}{\multicolumn{2}{|c|}{2008}} & \multirow{2}{*}{\multicolumn{2}{|c|}{2009}} & \multicolumn{4}{|c|}{ R\$ Milhão } \\
\hline & & & & & & & & & 2010 & & 2011 & \\
\hline & RS & $\mathbf{N}^{0}$ & RS & $\mathbf{N}^{0}$ & RS & $\mathbf{N}^{0}$ & RS & $\mathbf{N}^{0}$ & RS & $\mathbf{N}^{\circ}$ & RS & $\mathbf{N}^{0}$ \\
\hline Agroindústria & - & - & 10,96 & 14 & 46,65 & 23 & 18,90 & 20 & 9,06 & 10 & 11,61 & 13 \\
\hline Alimentos & 3,31 & 4 & 17,29 & 14 & 32,68 & 33 & 28,72 & 40 & 47,29 & 46 & 26,63 & 57 \\
\hline Bens de Consumo & 0,39 & 2 & 51,88 & 21 & 93,14 & 33 & 79,82 & 37 & 112,07 & 46 & 82,84 & 52 \\
\hline Construção Civil & 0,69 & 3 & 4,54 & 7 & 12,37 & 17 & 12,04 & 17 & 7,87 & 7 & 13,82 & 13 \\
\hline Eletro-Eletrônica & 8,03 & 13 & 41,19 & 44 & 70,20 & 66 & 54,61 & 53 & 73,98 & 42 & 110,71 & 65 \\
\hline Farmacêutica & 20,65 & 11 & $\mathbf{3 4 , 7 9}$ & 14 & $\mathbf{4 4 , 1 8}$ & 16 & 69,57 & 31 & 84,15 & 37 & 76,39 & 37 \\
\hline Mecânica e Transportes & 87,27 & 30 & 340,02 & 81 & 728,22 & 114 & 539,13 & 111 & 701,89 & 147 & 552,89 & 154 \\
\hline Metalurgia & 38,01 & 22 & 45,23 & 26 & 59,77 & 32 & 60.82 & 43 & 72.64 & 45 & 38,86 & 43 \\
\hline Mineração & 2,32 & 2 & 0,14 & 1 & 1,09 & 1 & 0,55 & 4 & 8,70 & 7 & 12,34 & 13 \\
\hline Moveleira & - & - & 3,35 & 8 & 5,97 & 11 & 3,98 & 14) & 1,55 & 8 & 6,98 & 21 \\
\hline Outras Indústrias & 34,16 & 11 & 32,47 & 29 & 25,53 & 32 & $\mathbf{5 7 , 7 8}$ & 44 & 158,79 & 104 & 190,51 & 146 \\
\hline Papel e Celulose & 5,91 & 3 & 10,29 & 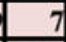 & 9,05 & 7 & 22,41 & 12 & 18,65 & 13 & 7,19 & 14 \\
\hline Petroquímica / Química & 21,71 & 22 & 271,66 & 26 & 356,14 & 34 & 347,61 & 55 & 375,31 & 67 & 219,98 & 70 \\
\hline Software & 6,07 & & 8,02 & 1 & 40,68 & 20 & 41,55 & 31 & 48,35 & 45 & 54,29 & 57 \\
\hline Telecomunicação & & & 9,09 & 3 & 55,62 & 17 & 43,51 & 21 & 2,90 & 6 & 2,28 & 2 \\
\hline Textil & 0,41 & 1 & 2,89 & 4 & 1,33 & 6 & $\begin{array}{r}1,72 \\
\end{array}$ & 9 & 3,88 & 9 & \begin{tabular}{|r|}
2,66 \\
\end{tabular} & 10 \\
\hline Total & 228,98 & 130 & 883,89 & 300 & $1.582,71$ & $\begin{array}{ll}460 \\
\end{array}$ & $1.382,76$ & \begin{tabular}{|l|}
542 \\
\end{tabular} & $1.727,13$ & 639 & $1.409,98$ & 767 \\
\hline
\end{tabular}

Fonte: MCT -2012

Esse fato pode estar associado a um dos fatores que acreditam serem padrões inibidores da competitividade de países em desenvolvimento, descritos na obra "Arando o Mar", em que a falta de relação de cooperação entre empresas pode ser a responsável por essa visão conservadora da mineração. Se as indústrias esperam se tornarem competitivas em termos globais, elas precisam criar um novo tipo de ambiente, onde os participantes de cada setor têm que assumir a 
responsabilidade de aprender e de cooperar para melhorar seu desempenho coletivo (FAIRBANKS et al., 2000).

Na maioria dos países em desenvolvimento, ocorre que a autossuficiência inibe o fortalecimento de relacionamentos interdependentes e limita a capacidade da empresa de reagir de forma inovadora a desafios estratégicos e competitivos (FAIRBANKS et al., 2000), ou seja, para que a mineração brasileira se torne mais sustentável, é necessário que seja mais eficiente no aproveitamento do bem mineral, consuma menos energia, reduza a geração de resíduos e impactos ambientais associados à sua operação e contribua para o desenvolvimento da região onde ela está inserida. Para isso, é fundamental a introdução de projetos inovadores em linhas de financiamento subsidiado e incentivos fiscais que podem contribuir para que os empreendimentos minerais sejam mais sustentáveis nos três aspectos: econômico, social e ambiental.

\subsection{Métodos de Gestão e Inovação}

Verifica-se que no Brasil as inovações tecnológicas ainda são um exercício (ERBER, 2004), que o país tem ficado para trás em comparação a outros países ocidentais e investir em avanço tecnológico é primordial para a recuperação da competitividade. No entanto, concentrar exclusivamente no desenvolvimento tecnológico de alguns setores, negligenciando a importância da capacitação e das estruturas locais de inovação, não é o caminho para que os objetivos sejam atingidos de forma adequada (ERBER, 2004).

A indústria de mineração não utiliza todo o seu potencial para gerar inovações, no geral, utiliza apenas uma pequena fração de seus investimentos em pesquisa, desenvolvimento e inovação. No entanto, para gerar inovações, não é necessário apenas aplicar recursos em PD\&I, necessita-se também investir na educação, aproveitando as habilidades das pessoas, com atenção especial para a gestão da inovação e envolvimento dos funcionários, fazendo com que os benefícios dos investimentos possam ser multiplicados.

Então, por que é necessário envolver os funcionários nas atividades de inovação de uma empresa? Cohen et al. (1972) relatam que inovação é dever de todos e 
que um problema fundamental em processos de inovação das empresas é a diferença entre os níveis hierárquicos. O nível operacional conhece os problemas, mas muitas vezes não possui soluções ou poder para mudar qualquer coisa. Ele pode ter soluções simples e a informação dificilmente irá chegar à gerência ou aos especialistas.

Os especialistas possuem as soluções mais elaboradas, conhecem as possibilidades da tecnologia, mas eles não conhecem intimamente os problemas e não possuem o poder de decisão.

O nível de gestão é que toma as decisões, mas para isso necessita da informação correta sobre o problema e as soluções. Isso pode levar a uma situação em que a gestão tem que tomar decisões com conhecimento parcial, pois, estando os especialistas isolados no departamento de PD\&I e os funcionários de nível operacional insatisfeitos, as coisas não funcionam, e as pessoas param de tentar promover mudanças, tornando o processo muito difícil.

Para tentar entender o problema, esta pesquisa foi organizada da seguinte forma:

1. Abordagens de gestão da inovação:

a. Melhoria contínua;

b. Inovação de alto envolvimento;

c. Inovação contínua;

d. Inovação aberta;

e. Prática baseada em inovação;

f. Funcionários orientados para inovação.

2. A inovação no setor de mineração no Brasil.

3. Proposta de abordagem para a inovação, considerando o modelo de quatro camadas para obter o envolvimento dos trabalhadores.

\subsection{Abordagens de Gestão da Inovação}

As organizações precisam equilibrar a padronização de suas operações com a mudança. Padronização eficaz de rotinas e práticas é essencial para a sobrevivência em curto prazo, mas alterações no ambiente exigem que as 
organizações busquem mudanças a longo prazo (ASHBY, 1960; HANNAN e FREEMAN, 1987; ELLSTROM, 2010).

O desafio básico da inovação é encontrar o equilíbrio adequado entre rotinas eficazes e renovação criativa. Nesse sentido, o conceito de inovação tem evoluído a partir da perspectiva do papel dos trabalhadores e por isso foram escolhidas as abordagens adequadas para a indústria da mineração. O que é comum a todas as abordagens é que todos em uma organização são capazes de contribuir com a inovação por meio de suas competências e habilidades (TIDD e BESSANT, 2009).

Do contrário, os conceitos que têm uma forte base na inovação relacionada ao cliente, não incluindo os funcionários, embora reconheçam os autores o efeito sobre o desenvolvimento do próprio conceito. Estes incluem como democratizar a inovação (HIPPEL, 2005) e cocriação (RAMASWHY e COILLART, 2004).

Os antecedentes da literatura de inovação de Schumpeter (1934) acreditavam que o valor a ser criado estava associado a ganho de escala e o escopo das atividades de $P \& D$ era basicamente interno.

Nelson (1959) introduziu o conceito de entradas externas de conhecimento, afirmando que os benefícios podem ser alcançados por meio de ideias que se originam fora departamentos de P\&D. O uso de conhecimento externo despertou forte oposição na forma do fenômeno do não-inventado-aqui (KATZ e ALLEN, 1982).

Conforme Cohen e Levinthal (1989) apontam, a capacidade de absorção pode oferecer uma explicação de como certas empresas investem em pesquisa básica, uma vez que os resultados saem da empresa para domínio público. Não é só na pesquisa básica que há investimento, mas também na capacitação dos funcionários para explorarem a informação externa disponível.

Cohen e Levinthal (1990) apresentaram as duas faces de P\&D: o conceito de capacidade de absorção de negócios e a aquisição de conhecimento a partir da assimilação de diferentes fontes disponíveis. 
Nesse processo de evolução sobre o desenvolvimento de inovação, foram consideradas as seguintes abordagens sobre $o$ assunto.

\subsubsection{Melhoria Contínua}

A melhoria contínua (BOER et al., 2000) é originado a partir de Kaizen japonês (IMAI, 1986) e ajustado para a cultura ocidental. Produção enxuta foi criada após a industrialização e a produção em massa. A ideia básica para se criar mais valor é reduzir todos os resíduos extras, por exemplo, o tempo, a quantidade de passos e o desperdício de material.

Tanto na literatura de gestão da qualidade (IMAI, 1986; LIKER, 2011) quanto em produção enxuta (LIKER, 2011, funcionários observam deficiências no processo de produção, sendo que cada um pode (e tem a obrigação) de observar o ambiente de trabalho. Muitas vezes, eles detectam os problemas que a administração não tem nenhum indício (COHEN et al., 1972).

Em Kaizen, indivíduo orientado (IMAI 1986, 110-124), o ponto de partida é conseguir com que o funcionário adote uma atitude positiva em relação à metodologia própria de melhoria contínua de trabalho. Intrinsecamente, funcionários de nível chão de fábrica motivados fazem o seu trabalho bem e não há necessidade de supervisioná-los (THOMAS e VELTHOUSE, 1990).

Nas empresas japonesas, o sistema de sugestões é mais do que apenas uma caixa no canto de uma fábrica. O sistema de sugestão de Kaizen (IMAI 1986, 111-124) é dividido em três etapas:

1. Os gestores devem levar a sério todas as sugestões, mesmo as mais primitivas, para obter a confiança dos trabalhadores para efetuarem o seu trabalho.

2. A administração deve investir na educação dos funcionários para que eles possam gerar melhores ideias.

3. Pensar sobre os impactos econômicos do sistema de sugestão. 


\subsubsection{Inovação de Alto Envolvimento}

Inovação de alto envolvimento foi proposta por Bessant e Caffyn (1997) para trazer as práticas de melhoria contínua para todos os níveis na organização. Bessant (2003) define oito características de inovação de alto envolvimento, entre elas, a capacidade da organização para estender a melhoria contínua através das fronteiras organizacionais e como a organização é capaz de capturar os resultados de aprendizagem provenientes de práticas de melhoria contínua.

Atividade de inovação, seja incremental ou radical, deve envolver não apenas aqueles cujo dever é associado a um projeto específico, mas também os trabalhadores qualificados e criativos que podem estar frustrados na situação atual (BESSANT, 2003).

\subsubsection{Inovação Contínua}

A melhoria contínua se encaixa bem em grandes organizações industriais, mas a discussão começou nas diferenças de melhoria contínua e inovação. Este último foi visto para ser mais criativo e renovado, enquanto a anterior era manter a posição estabelecida de mercado. Além disso, a questão sobre os riscos e erros entrou em cena. Consideram-se as abordagens - gestão da qualidade busca a perfeição, enquanto inovação inclui incerteza e erro (COLE, 2002).

Indivíduos nas organizações são vistos como fonte essencial de ideias (BJÖRK et al., 2010), sendo que o fluxo contínuo de ideias garante a inovação a longo prazo. Por isso é necessário estabelecer sistemas para estimular a geração de ideais de diferentes formas, tais como concursos ou campanhas (BJÖRK et al., 2010).

\subsubsection{Inovação Aberta}

A pesquisa de inovação mudou do fechado P\&D para abrir ambientes de inovação (CHESBROUGH, 2003; CHESBROUGH et al., 2006). Primeiramente foi definida como inovação tecnológica, mais tarde, a definição foi cristalizada como inovação aberta, conceituada por Chesbroug et al. (2006, p. 1) como sendo 
"o uso de entradas intencionais e saídas de conhecimento para acelerar a inovação interna e expandir os mercados para uso externo da inovação".

Lichtenhaler (2011) divide a inovação aberta em três características:

1. Transferência de conhecimento para dentro e para fora (CHESBROUGH, 2006);

2. Organização interna e externa dos processos de gestão do conhecimento (CHESBROUGH, 2003);

3. Integração da investigação tecnológica e da pesquisa aplicada em gestão da inovação (LICHTENHALER, 2011).

A inovação aberta estabeleceu novos tipos de demandas para os inovadores, por exemplo, em formas de produção coletiva de conhecimento, redes de inovação e conhecimento, bem como as habilidades necessárias (PIHKALA e HARMAAKORPI, 2011).

Pihkala e Harmaakorpi (2011, p 2) observaram quatro tipos de organizações (em relação à cultura corporativa e empreendedorismo): 1 . fechada para dentro e para fora, 2. fechada para dentro, mas aberta para fora, 3. aberta para dentro, mas fechada para fora e 4 . aberta para dentro e para fora.

Dentro da organização, inovação aberta significa a criação de práticas de gestão para a exploração e retenção do conhecimento (LICHTENHALER, 2011). Exemplos práticos na literatura incluem, por exemplo, os famosos sistemas de gestão ideias da Procter \& Gamble, a aquisição externa de conhecimentos para inovações (HUSTON e SAKKAB, 2006) e internamente (DODGSON et al., 2006). Em menor escala, Kallio e Bergenholtz (2012) examinaram os mecanismos sociais e individuais da abordagem tradicional de caixa de sugestões.

Em algum lugar entre o desenvolvimento da inovação contínua e inovação aberta, o papel do funcionário lentamente deixou de ser passivo para ser mais ativo. Mesmo que tenha havido coisas como a auto-organização de equipes de antes, agora os funcionários têm mais poder para participar da tomada de decisão e das práticas organizacionais. 


\subsubsection{Inovação Baseada na Prática}

O princípio de inovação baseada na prática refere-se ao equilíbrio entre a produção de conhecimento da ciência e a aprendizagem na experiência (LUNDVALL, 2007; HARMAAKORPI e MELKAS, 2012). Harmaakorpi e Melkas (2012) dividiram a inovação prática em duas dimensões: atividades entre diferentes empresas e desenvolvimento interno da organização.

Geração de conhecimento e aprendizagem em CTI (Ciência-TecnologiaInovação) (JENSEN et al., 2007) baseiam-se na produção de conhecimento especializado e difusão do conhecimento codificado. O efeito de alavancar a ciência como força motriz das inovações é uma exceção e não uma regra nos processos de inovação (SCHIENSTOCK e HÄMÄLÄINEN, 2001).

Por outro lado, as inovações parecem presumir fatores como a capacidade de interagir, aprender coletivamente e construir relações de confiança entre os parceiros inovadores (HARMAAKORPI, 2004). Processos de FUI (FazendoUtilizando-Interagindo) são processos informais de aprendizagem baseados na experiência e no conhecimento (JENSEN et al., 2007).

\subsubsection{Funcionários Orientados para Inovação}

Funcionários orientados para inovação é originado da atividade sindical na Dinamarca (LO, 2007). Impulsionados pela tendência de globalização, os sindicatos na Dinamarca queriam manter elevada taxa de emprego apesar do deslocamento para países de baixo custo (LO, 2007).

De acordo com o EDI, as inovações podem surgir de qualquer parte das organizações e de qualquer grupo de funcionários (KESTING e ULHOI, 2010; HOYRUP, 2010).

Um P\&D forte e orientado para a tecnologia leva também aos preconceitos que cercam o desenvolvimento futuro. Por exemplo, na Finlândia, uma visão muito focada em tecnologia tornou uma barreira para implementar a abordagem funcionários orientados para inovação (ALASOINI, 2013). 
A participação dos funcionários na Finlândia foi gerida por meio da estrutura de pensamento enxuto que favorece a participação dentro de estreitos limites estabelecidos pela administração, ao contrário do que acontece em outros países escandinavos, como a Suécia e a Dinamarca, onde a abordagem é centrada no ser humano (LORENZ e LUNDVALL, 2011; VALEYRE et al., 2.009).

\subsection{Inovação no Setor de Mineração no Brasil}

Em muitos estudos que analisam a inovação na indústria de mineração, a inovação é vista como a inovação tecnológica (UPSTILL e HALL, 2006). No entanto, existe o potencial de inovação também em outras áreas, por exemplo, a inovação de processo (KLIPPEL et al., 2008), as inovações de serviços (DE TOMl et al., 2012), as inovações culturais (DE TOMl et al., 2010) e também sustentabilidade que deverá ser um dos principais elementos da mineração no futuro (FILIPPOU e KING, 2011; BATTERHAM, 2006).

De Tomi et al. (2010) listam os principais desafios para o setor de mineração brasileiro: rentabilidade, sustentabilidade, legislação, política e introdução de inovações. Filippou e King (2011) dizem que globalmente as indústrias de mineração e metalurgia enfrentam altas pressões para reduzir o consumo energético e as emissões de dióxido de carbono.

Além disso, em geral, no Brasil, há falta de dinamismo no setor empresarial (CANUTO et al., 2013). A competitividade não é conseguida, apenas, trazendo mais tecnologia estrangeira, a meta de investimento mais importante é o desenvolvimento de pessoal qualificado (CANUTO et al., 2013), uma vez que um dos principais obstáculos é o baixo nível educacional dos trabalhadores de nível operacional (WALLACE, 2004).

No contexto da mineração brasileira, o envolvimento dos funcionários nas atividades de inovação é um grande desafio. Em geral, a inovação nessas organizações ainda é bastante fechada e o estilo de gestão, especialmente no setor de mineração, é essencialmente autoritário. Há ainda tensão devido à punição pelos erros e, portanto, os funcionários não estão dispostos a correr 
riscos. Inovação, por outro lado, favorece as circunstâncias em que os funcionários podem assumir riscos sem serem punidos.

De Tomi et al. (2010) consideram que o foco das iniciativas de inovação das empresas de mineração é o de gerir os investimentos, custos de produção e os custos de recuperação, sem prejudicar a qualidade e a segurança do produto.

Silva Saraiva e Moura Andrade (2009) examinaram o envolvimento dos trabalhadores no setor de mineração. Eles relatam como a educação a distância pode ser usada como ferramenta para o desenvolvimento dos funcionários, no entanto, estes sentem que estão tendo mais trabalho, pois estão estudando no período de descanso. Dessa forma, não é suficiente que a empresa ofereça-Ihes apenas a infraestrutura para o estudo. Ela também deve ser capaz de comunicar aos funcionários a visão da empresa e como o envolvimento deles está ligado a atingir essa visão (SILVA SARAIVA e MOURA ANDRADE, 2009).

Filippou e King (2011) mencionam que o aumento da demanda dos países em desenvolvimento é uma possibilidade para a mineração, mas também pode ser um obstáculo para a inovação. Se a demanda é muito boa, a isca para continuar o negócio, como de costume, é tentador.

Mesmo que o trabalho e a educação de um engenheiro de minas brasileiro envolvam várias funções, ele enfrenta um desafio como a falta de uma base sólida em ciência da engenharia. Isso impede que as funções sejam eficazes nos trabalhos técnicos em mineração. A educação é ampla como consequência da realidade brasileira, mas é prejudicial para as demandas de um país desenvolvido (CHAVES, 1995). O estudo de Arthur Pinto Chaves foi anterior a 1995 e a educação tem, sem dúvida, progredido. No entanto, muitos dos funcionários da mineração estudaram nas condições anteriores a 1995. 


\subsection{Proposta de Abordagem de Gestão da Inovação}

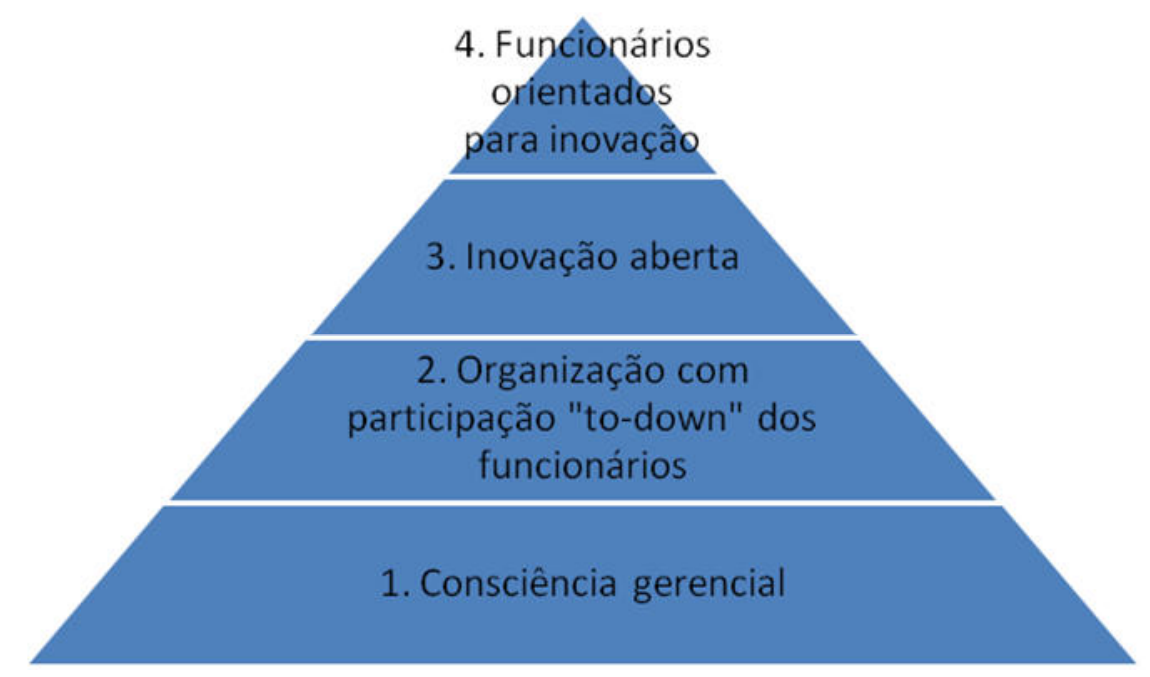

Figura 8: As camadas de envolvimento dos trabalhadores na mineração

As camadas que foram propostas são:

1. Conhecimento gerencial - Os gestores querem que seus funcionários sejam mais ativos. Eles dão espaço para a tomada de decisões, assumindo riscos e aprendendo com os erros.

2. Organização top-down com participação dos funcionários - Os funcionários são encarregados de emitir parecer em uma área restrita.

3. Inovação aberta - Os funcionários são livres para gerar ideias e fazer sugestões. O processo de como as ideias são avaliadas é transparente.

4. Funcionários orientados para inovação - Os funcionários participam na criação de seus papéis. A motivação individual é o foco dessa abordagem, e os funcionários participam na definição da estratégia organizacional.

Esse modelo de trabalho propõe apoiar a mineração no desafio da introdução de inovações de forma sustentável (DE TOMl et al., 2012.), não só para introduzir novas tecnologias, mas também para preparar as organizações e as pessoas responsabilizarem-se pela sua própria mudança (CANUTO et al., 2013.).

No modelo apresentado para aumentar o envolvimento dos trabalhadores na mineração, as camadas estão em ordem de nível de maturidade que as 
organizações necessitam ter e é fundamental que os líderes sejam envolvidos antes dos demais funcionários (RUSSELL, 1999).

Portanto, em todos os casos, para que o modelo adotado tenha sucesso, é fundamental um ambiente propício para a contribuição de todos os envolvidos, ou seja, é necessário um sistema de gestão participativo e que permita correr riscos. Talvez este seja o maior desafio para a mineração brasileira, pois é necessária uma mudança na cultura dominante no setor.

\subsection{Fatores Históricos e Culturais que Dificultam o Desenvolvimento da Inovação no Brasil}

Pode-se dizer que a chave do entendimento dos fatores que dificultam o desenvolvimento da inovação no Brasil está na forma como o Brasil se formou. Para isso, é importante que se faça uma análise dos estágios da administração no Brasil. Costuma-se cronologicamente dividir a gestão brasileira em três modelos: a) patrimonialista, que caracteriza o Império e a Primeira República; b) burocrático, que nasce com o primeiro governo Vargas, passa pela Reforma Burocrática de 1936 e pela reforma desenvolvimentista de Castelo Branco e c) gerencial, a partir de 1995 (BRESSER PEREIRA, 2001).

Essa classificação, apesar de elucidativa, não significa a existência estanque dos modelos. Em todos eles, há coexistência e influência dos modelos anteriores. No Estado oligárquico e patrimonial, o governante administrava o patrimônio público como se fosse seu patrimônio privado.

O poder político do Estado estava concentrado em um estamento aristocrático burocrático de juristas, letrados e militares, que derivam seu poder e sua renda do próprio Estado. Raymundo Faoro, que estudou exaustivamente esse período, não nega a força política dos senhores de terra e de escravos, mas entende que o Estado estava baseado no estamento patrimonial e não senhorial. Na verdade, a renda da terra sustentava a rede de relações determinadas pelo estamento, grande leva de funcionários de nível médio a ele ligados ao Estado por laços de toda ordem. 
O patrimonialismo, sintetizando, tende a associar o trato da coisa pública pela autoridade como se privada fosse. $O$ estamento burocrático se fundamenta num sistema patrimonial, clientelista e cartorial.

Essa característica, herdada de Portugal, consiste na apropriação de funções, órgãos e rendas públicas por setores privados dependentes do poder central e subordinados a ele. De acordo com Raymundo Faoro, o governo não se determina pela maioria, mas pela minoria que, a pretexto de representar o povo, o controla e o deturpa (FAORO, 2001, p. 104).

No Estado patrimonial, o agente, funcionário público, que está por toda parte para representar o rei, dirige a economia, controlando-a e limitando-a à sua própria determinação. O cargo público, almejado por todos, confere, a poucos, fidalguia e riqueza. Ao funcionário, cabe se perpetuar no exercício da parcela do poder que o acompanha para auferir vantagens e benefícios.

Visando centralizar o poder, o Estado se alicerça em uma constelação de cargos e agentes que, a princípio, deveriam ser a sombra do rei. No entanto, atrás da enxurrada de funcionários, estava a ruína do Estado, superfaturado pelas subvenções, pelos ordenados e pelas pensões, para proveito de ostentação da fidalguia encasulada no cargo público (FAORO, 2001, p.104-105).

A organização política fecha-se sobre si próprio como estamento, de caráter marcadamente burocrático. Burocracia, como ressalta Faoro (2001, p.104-105), "não no sentido moderno, como aparelhamento racional, mas da apropriação do cargo, carregado de poder próprio".

Os cargos públicos, criados pelo rei para se fazer onisciente e onipresente nos domínios coloniais, visando, dessa forma, à centralização política, acabam por se distanciar da administração pública, tornando-se autônomos e independentes (FAORO, 2001, p. 197).

A aliança estabelecida entre a coroa e os segmentos agrários dominantes permitiu um modelo de Estado sustentado na herança colonial burocrática e 
patrimonialista em benefício dos donos do poder. Estruturado pelo uso das parentelas e clientelas, o Estado foi apropriado em benefício de interesses próprios. O senhor das terras e de escravos vivia em regime quase autárquico, com poder soberano para fazer justiça e manter força militar própria, para defesa e ataque (FAORO, 2001, p. 256). Esse individualismo acentuou o uso das parentelas e clientelas dentro da máquina pública.

No Império, enquanto os senhores de terra e escravos se ocupavam da economia, o estamento patrimonialista dominava com relativa autonomia o Estado e a política.

Tinha-se, na verdade, uma aliança do estamento patrimonialista com a burguesia mercantil de senhores de terra e grandes comerciantes. De acordo com Bresser Pereira (2001), são todos burocratas,

\footnotetext{
porque sua renda deriva essencialmente do Estado; são patrimonialistas porque os critérios de sua escolha não são racional-legais, e porque constroem um complexo sistema de agregados e clientes em torno de si, sustentado pelo Estado, confundindo o patrimônio privado com o estatal. Os critérios administrativos eram pessoais, e a preocupação com a eficiência da máquina estatal era nula.
}

O segundo modelo de gestão administrativa no Brasil foi o Estado burocrático que promoveu uma reforma do serviço público na Primeira República. A estrutura econômica e a de poder não haviam mudado, assim o regime continuava oligárquico. A Constituição de 1891, que estabeleceu a federação e a descentralização política, acentuou o poder dos governadores e das oligarquias locais. No entanto, apesar de o poder dos governadores ter aumentado em relação à União, ele passou a depender mais dos chefes locais (BRESSER PEREIRA, 2001).

O desejo dos militares por ordem e progresso e o desejo dos liberais por democracia resultaram na aliança política desses segmentos em 1930, que acabou levando o Estado à burocracia e ao autoritarismo do primeiro governo de Vargas, que perdurou no poder por quinze anos, cujos últimos oito anos foi estritamente autoritário e burocrático. A nova burocracia, composta pela burguesia industrial, originária dos estamentos antigos, passava a ter uma 
função econômica essencial, assumindo a coordenação das grandes empresas produtoras de bens e serviços.

Para realizar a reforma do serviço público, foi criado, em 1936, o Conselho Federal do Serviço Público Civil. Em 1937, foram feitos concursos para contratação dos funcionários públicos e, no ano seguinte, efetiva-se o regime burocrático com a criação do Departamento Administrativo do Serviço Público (DASP), que passou a ser o poderoso órgão executor da Reforma Burocrática de 1936.

A Reforma de 1936 não foi capaz de eliminar o velho patrimonialismo, dando vazão, no regime futuro, ao clientelismo e às relações de dependência. Em 1963, nova reforma administrativa foi realizada pelo então presidente João Goulart, mas que só foi implementada com o golpe de Estado de 1964. Por quase vinte anos, o Brasil teve um regime autoritário modernizador, burocrático capitalista, que uniu a moderna burocracia civil e militar com as classes médias burocráticas do setor privado. A reforma procurou substituir a administração pública burocrática por uma "administração para o desenvolvimento": distinguiu com clareza a administração direta da administração indireta, garantiu-se às autarquias e fundações deste segundo setor, e também às empresas estatais, uma autonomia de gestão muito maior do que possuíam anteriormente, fortaleceu e flexibilizou o sistema do mérito, tornou menos burocrático o sistema de compras do Estado (BRESSER PEREIRA, 2001).

Ao mesmo tempo em que o poder ficava novamente centralizado nas mãos do governo federal, a reforma administrativa conduzia à descentralização administrativa, pela maior autonomia de decisão das agências, que viabilizavam o desenvolvimento industrial. As empresas estatais, bem como outras entidades da administração indireta, lutavam constantemente para aumentar sua autonomia como forma de defender seus objetivos ou preservar seus privilégios corporativos dentro das estruturas do Estado.

O Executivo, por sua vez, não conseguiu limitar essas tendências, e a lógica do sistema corporativo conseguiu se infiltrar nas redes do Estado (MARTINS, p. 
238). Empregados foram contratados sem concurso público, o que facilitou a sobrevivência de práticas clientelistas ou fisiológicas.

Isso nos mostra que a cultura política do Brasil é profundamente enraizada em uma herança colonial patrimonialista. Apesar das enormes mudanças econômicas e sociais que o País sofreu, o nepotismo, o favoritismo e o clientelismo, sob diferentes formas, tornaram-se características culturais persistentes. Isso moldou tanto a percepção da sociedade com respeito ao Estado como a organização da administração pública (MARTINS, 1997).

Estruturado sob a égide do patrimonialismo e do estamento burocrático, o país sobrevive mergulhado em uma base pouco eficiente. As características de estamento burocrático têm atravessado toda a história política brasileira. Com aparelhamento próprio, o estamento burocrático invade e dirige a esfera econômica, política e financeira, estreitando os laços do que é público e do que é privado.

No campo financeiro, prevalece o capitalismo politicamente orientado. O Estado personificado nas relações estamentais, em vista dos interesses particulares de determinados grupos, não assume o papel de fiador e mantenedor de uma ordem jurídica impessoal e universal, que possibilite aos agentes econômicos 0 livre desenvolvimento de suas potencialidades.

O estamento freia as novas ideias, impedindo que as ideologias perturbem 0 domínio da sociedade, tradicionalmente cunhado para favorecimento de grupos, ancorados num passado teimosamente fixado na alma da nação. Campante (2003), tomando como forma o estudo de Raimundo Faoro sobre o patrimonialismo, argumenta que, do ponto de vista econômico,

não há "regras do jogo" estáveis na economia, pois elas atendem ao subjetivismo de quem detém o poder político. Esse tipo de capitalismo adota do moderno capitalismo a técnica, as máquinas, as empresas, sem Ihe aceitar, todavia, a "alma" - a racionalidade impessoal e legaluniversal. Um arranjo tradicional, mas maleável em face da modernidade capitalista, a qual aceita seletivamente, mas sem vender a alma conformada à racionalidade personalista e casuística. $O$ capitalismo não 
brota espontaneamente na sociedade, mas vicia-se no estímulo e na tutela estatal: tire-se do capitalismo brasileiro o Estado e pouco ou nada sobrará, adverte Faoro.

Estudar a administração é estudar a dominação, pois só assim se consegue entender a distribuição de poderes de mando e obediência e como se sustenta as relações de autoridade e legitimidade do poder. No caso do patrimonialismo, além da descentralização, que permite ao Estado ser onipresente, um traço forte desse sistema é a ineficiência governamental. Campante explica que

os fundamentos personalistas do poder, a falta de uma esfera pública contraposta à privada, a racionalidade subjetiva e casuística do sistema jurídico, a irracionalidade do sistema fiscal, a não-profissionalização e a tendência intrínseca à corrupção do quadro administrativo, tudo isso contribui para tornar a eficiência governamental altamente problemática no patrimonialismo (...). E como tal eficiência é um dos atributos básicos do capitalismo moderno, todos esses fatores mencionados funcionam, também, como um obstáculo à constituição deste em sociedades patrimoniais.

A inércia e a inaptidão dos segmentos hegemônicos de nossa estrutura social patrimonialista foram responsáveis por obstáculos às inovações.

A Sociedade Senhorial, de senhores e escravos, controlada pelo pequeno estamento burocrático estatal, deu lugar a uma nova classe média burocrática ou tecno-burocrática pública e privada. Estas passaram a dividir com a alta burguesia não apenas o poder mas também o excedente econômico. A nova classe média profissional passou a controlar o conhecimento técnico e organizacional.

Hoje, conforme observou Bresser Pereira, a economia brasileira está mais rica, composta por uma sociedade mais diversificada, um Estado mais democrático, uma administração pública menos patrimonialista e mais gerencial. No plano político, adverte Bresser Pereira, transitamos do Estado oligárquico ao Estado democrático (de elites); no administrativo, do Estado patrimonial ao Estado gerencial; no plano social, da Sociedade Senhorial para a Sociedade PósIndustrial. No entanto, essa sociedade continua esperando que o Estado garanta 
as condições para sua continuidade independente das mudanças externas que ocorram; ou seja, apesar de um mundo globalizado em constante transformação, o empresariado brasileiro continua trabalhando de forma conservadora.

\section{MODELO PROPOSTO}

A hipótese assumida para este estudo é que a mineração brasileira poderia ser mais sustentável se os projetos minerais fossem desenvolvidos com a introdução de inovações tecnológicas, buscando otimizar ou o aproveitamento dos minérios, ou introduzir melhorias no processo produtivo, ou desenvolver novas aplicações ou melhorias em produtos, ou desenvolver arranjos mais sustentáveis para os empreendimentos minerais.

No entanto, a indústria de mineração não é sinônimo de inovação, os métodos de extração foram desenvolvidos há décadas, e muitas empresas estão satisfeitas em manter os mesmos processos e equipamentos que são padrão em todo o setor. "Há uma barreira enorme para ninguém tentar fazer nada de novo, porque todo mundo pensa o mesmo." (Bamber, 2014). No Brasil este fato pode ser comprovado pelo fato de a mineração ser o setor que menos utilizou os incentivos fiscais da Lei do Bem para inovação (MCTI, 2012).

As empresas que atuam no setor mineral são, na maioria dos casos, extremamente conservadoras, desenvolvendo projetos somente com tecnologias consagradas no mercado. Dessa forma, atualmente são adotados os seguintes conceitos para o desenvolvimento de projetos de mineração:

- Selecionar para o desenvolvimento dos estudos apenas as tecnologias que já foram consagradas na mineração, buscando reduzir os riscos e os custos envolvidos e agilizar a conclusão dos estudos e projetos;

- Estabelecer metas ousadas de investimentos e prazos para a conclusão do projeto, pois estes são objetivos sempre presentes nas empresas desse setor;

- Desenvolver o projeto considerando elevada capacidade produtiva, com visão tradicional da indústria extrativa, com baixo envolvimento da 
comunidade e dos órgãos envolvidos no licenciamento ambiental na fase de projeto;

- Trabalhar com equipe formada com pessoal próprio e empresas de consultoria, tendo pouco envolvimento de universidades e centros de pesquisa de elevada credibilidade; isso busca projetos mais focados em resultados rápidos e mais alinhados à visão da empresa;

- Utilizar planta-piloto de pequeno porte, focada apenas no desenvolvimento de processo mineral, sem possibilitar a avaliação das demais variáveis envolvidas no empreendimento;

- Considerar o financiamento apenas para a fase de implantação, sendo que os estudos e projetos devem ser desenvolvidos com recursos próprios;

- Prever, para começo da operação, 5 anos após o início do projeto, sendo que o principal desafio está associado ao licenciamento ambiental.

No entanto, existe uma série de incentivos para inovação tecnológica que poderia ser aproveitada pelas empresas de mineração se elas fossem mais abertas a novas tecnologias, podendo tornar os empreendimentos minerais mais competitivos e sustentáveis.

A abordagem proposta poderá contribuir nos seguintes aspectos:

1. Financiamento para as fases de exploração mineral e de projeto;

2. Análise da viabilidade de introdução de novas tecnologias nos empreendimentos minerais;

3. Redução das incertezas associadas ao recurso mineral, ao processo de beneficiamento, a qualidade dos produtos, a destinação dos resíduos e aos impactos socioambientais;

4. Agilização do licenciamento ambiental;

5. Redução do risco do negócio pela utilização de recursos (humanos e financeiros) muito competitivos, facilitando a viabilização de novos empreendimentos sustentáveis de mineração.

Essa nova abordagem consiste, de forma resumida, em: 
- Estruturar um projeto de inovação para a obtenção de financiamento subsidiado e de incentivos fiscais;

- Investir de forma mais intensa nos estudos e projetos, de preferência em parceria com renomadas instituições de pesquisa, considerando um valor bem maior que o do modelo tradicional;

- Desenvolver o projeto como uma visão mais abrangente do que a normalmente adotada na indústria extrativa, considerando a mineração como um potencial agente de desenvolvimento regional;

- Implantar uma unidade-piloto para validar as premissas e otimizar o processo no prazo de 18 a 24 meses do início do projeto, de forma que o resultado financeiro dessa instalação possa, pelo menos, garantir o pagamento do financiamento;

- Operar a unidade-piloto por um período de 6 a 12 meses para validar as premissas, otimizar os processos, desenvolver produtos, avaliar riscos e projetar a unidade definitiva para aproveitamento otimizado de um depósito mineral;

- Permitir a avaliação efetiva da condição operacional em escala-piloto, com envolvimento da comunidade e dos órgãos ambientais, reduzindo os riscos associados e, consequentemente, agilizando o licenciamento da operação-piloto e da definitiva.

Para comparar a nova abordagem em relação à tradicional, foi considerado o impacto sobre o risco do fluxo de caixa de cada abordagem, sendo que, para essa análise, foi adotada a seguinte metodologia:

1. Construção de modelos do projeto mineração (produção, custos, teores, preços, etc.) segundo a nova abordagem e modelo tradicional;

2. Identificação das variáveis críticas que impactam nos fluxos de caixa anuais do projeto bem como em seus indicadores (VPL e TIR);

3. Comparação em base determinística dos fluxos de caixa com e sem inovação;

4. Simulação de Monte Carlo de modo a determinar o risco de VPL negativo para cada um dos modelos;

5. Identificação das variáveis que mais afetam o nível de risco do VPL dos modelos;

6. Análise de resultados das simulações e seleção da melhor alternativa. 


\subsection{Construção de Modelos do Projeto Mineração (produção, custos, teores, preços, etc.) Segundo a Nova Abordagem e Modelo Tradicional}

Os métodos específicos de pesquisa que foram utilizados no desenvolvimento deste projeto são os seguintes:

- Investigação - por meio de pesquisa bibliográfica, foram levantadas as metodologias existentes e outras questões que pudessem contribuir para atingir os resultados esperados. Foram identificadas e selecionadas as alternativas que possibilitassem o incremento da inovação na mineração brasileira de forma a contribuir para a sua sustentabilidade.

- Desenvolvimento - com base na investigação efetuada, foram identificadas as alternativas que pudessem ser aplicadas para tornar a mineração de ferro do Quadrilátero Ferrífero mais sustentável, e foi proposta uma abordagem de projeto de inovação que contribuísse para 0 ganho de competitividade da mineração.

- Avaliação - a abordagem proposta para projeto de inovação foi comparada com o padrão adotado para projetos minerais tradicionais no Quadrilátero Ferrífero por meio da modelagem dos dois cenários e a simulação de variação de fatores de impacto na competitividade.

- Validação - a validação da proposta de abordagem foi efetuada por meio de avaliação das informações e interpretação dos resultados da simulação.

$\mathrm{Na}$ presente pesquisa, foram desenvolvidos dois pontos principais para estabelecer um caminho para o fortalecimento da sustentabilidade na mineração brasileira:

- A necessidade da introdução de inovações tecnológicas para tornar a mineração mais sustentável;

- A aplicação dos mecanismos de fomento à inovação para a competitividade e sustentabilidade da mineração brasileira. 


\subsection{Conceitos que Nortearam a Abordagem Proposta}

A abordagem proposta está baseada nas demandas das minerações brasileiras para o ganho de competitividade na cultura empresarial dominante e nos mecanismos de fomento à inovação existentes no Brasil. Ela foi estabelecida com base nos conceitos a seguir.

\subsubsection{Inovação é Mais Simples que o Considerado Normalmente}

Muitas das melhorias que são desenvolvidas na mineração podem ser caracterizadas como inovação, podendo, dessa forma, obter financiamentos subsidiados e incentivos fiscais. Para isso, é necessário que essas melhorias sejam desenvolvidas por meio de projetos estruturados adequadamente.

Isso pode ser observado no gráfico de Altshuller (NICOLSKY, 2011) apresentado a seguir, onde, num universo de 250 mil patentes, apenas 10\% delas são decorrentes de descobertas e novas invenções, e os $90 \%$ restantes estão associados a projetos de melhoria.

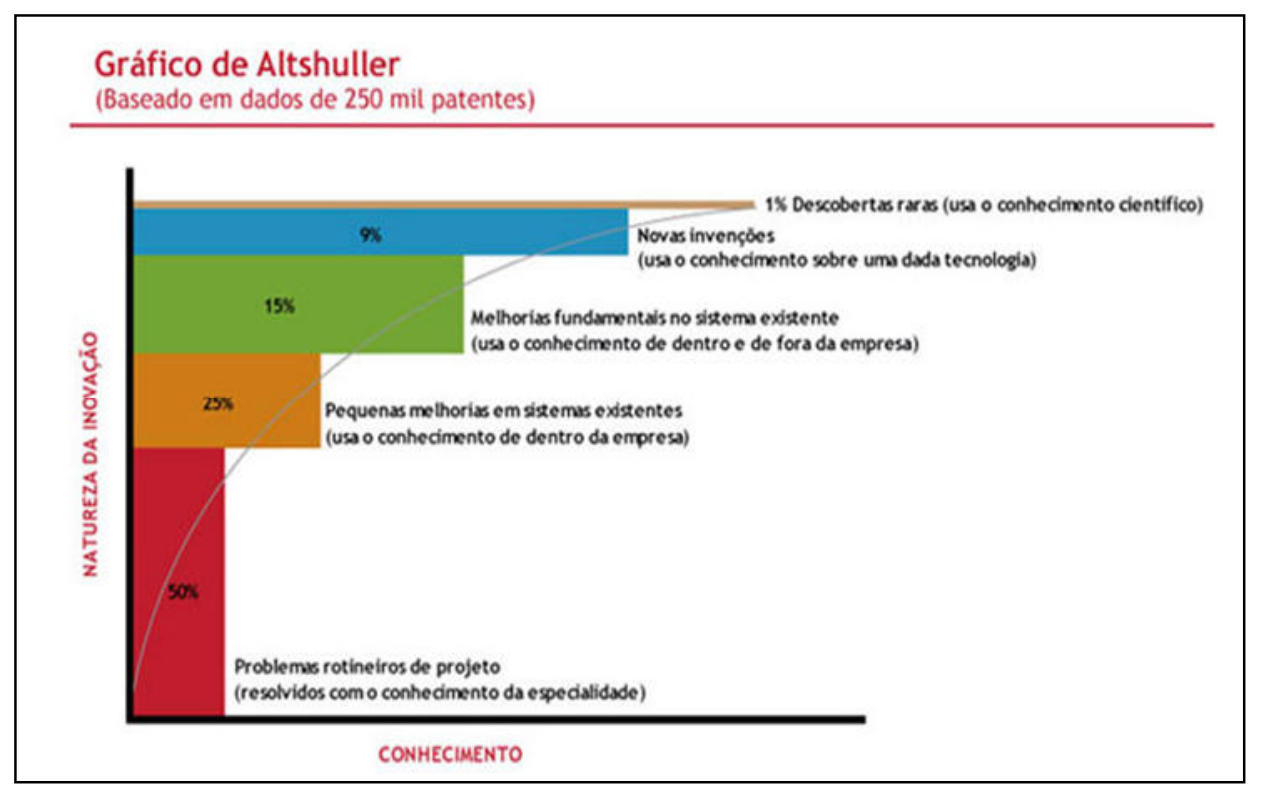

Figura 9: Gráfico de Altshuller

O decreto no 5.798 de 07.06 .2006 , que regulamenta os incentivos fiscais às atividades de pesquisa tecnológica e desenvolvimento de inovação tecnológica, 
de que tratam os artigos 17 a 26 da Lei $n^{0}$ 11.196, de 21 de novembro de 2005 (Lei do Bem), apresenta os seguintes conceitos no artigo $2^{\circ}$ :

Art. $2^{\circ}$ Para efeitos deste Decreto, consideram-se:

I - inovação tecnológica: a concepção de novo produto ou processo de fabricação, bem como a agregação de novas funcionalidades ou características ao produto ou processo que implique melhorias incrementais e efetivo ganho de qualidade ou produtividade, resultando maior competitividade no mercado;

II - pesquisa tecnológica e desenvolvimento de inovação tecnológica, as atividades de:

a) pesquisa básica dirigida: os trabalhos executados com o objetivo de adquirir conhecimentos quanto à compreensão de novos fenômenos, com vistas ao desenvolvimento de produtos, processos ou sistemas inovadores;

b) pesquisa aplicada: os trabalhos executados com o objetivo de adquirir novos conhecimentos, com vistas ao desenvolvimento ou aprimoramento de produtos, processos e sistemas;

c) desenvolvimento experimental: os trabalhos sistemáticos delineados a partir de conhecimentos preexistentes, visando à comprovação ou demonstração da viabilidade técnica ou funcional de novos produtos, processos, sistemas e serviços ou, ainda, um evidente aperfeiçoamento dos já produzidos ou estabelecidos;

d) tecnologia industrial básica: aquelas tais como a aferição e calibração de máquinas e equipamentos, o projeto e a confecção de instrumentos de medida específicos, a certificação de conformidade, inclusive os ensaios correspondentes, a normalização ou a documentação técnica gerada e o patenteamento do produto ou processo desenvolvido;

e) serviços de apoio técnico: aqueles que sejam indispensáveis à implantação e à manutenção das instalações ou dos equipamentos destinados, exclusivamente, à execução de projetos de pesquisa, 
desenvolvimento ou inovação tecnológica, bem como à capacitação dos recursos humanos a eles dedicados.

Os conceitos de inovação tecnológica e pesquisa tecnológica, apresentados na Lei do Bem, são muito amplos, permitindo que o enquadramento, como inovação de muitos projetos, não seja hoje caracterizado como tal pela maioria das empresas brasileiras de mineração. Com isso, muitos dos investimentos que são efetuados na mineração brasileira poderiam se beneficiar de financiamentos subsidiados e incentivos fiscais, contribuindo fortemente para o desenvolvimento sustentável desse setor.

\subsubsection{Caminhar Juntos}

O desenvolvimento de inovações não é uma tarefa simples, por isso estabelecer condições favoráveis é fundamental para fomentar as inovações e ganhar competitividade. No entanto, não basta apenas disponibilizar financiamentos subsidiados e incentivos fiscais, é necessário muito mais do que isso. De acordo com Munroe et al. (2008), ecossistema é um conjunto completo de relações entre os recursos vivos e o ambiente de uma região. E desenvolver um Ecossistema de Inovação é fundamental para o desenvolvimento tecnológico de uma região ou de um setor empresarial.

O sucesso do Vale do Silício, tido por muitos como o benchmarking mundial em inovação, está associado ao Ecossistema de Inovação, baseando-se em seis elementos- chave, apresentados na Figura 10 a seguir. 


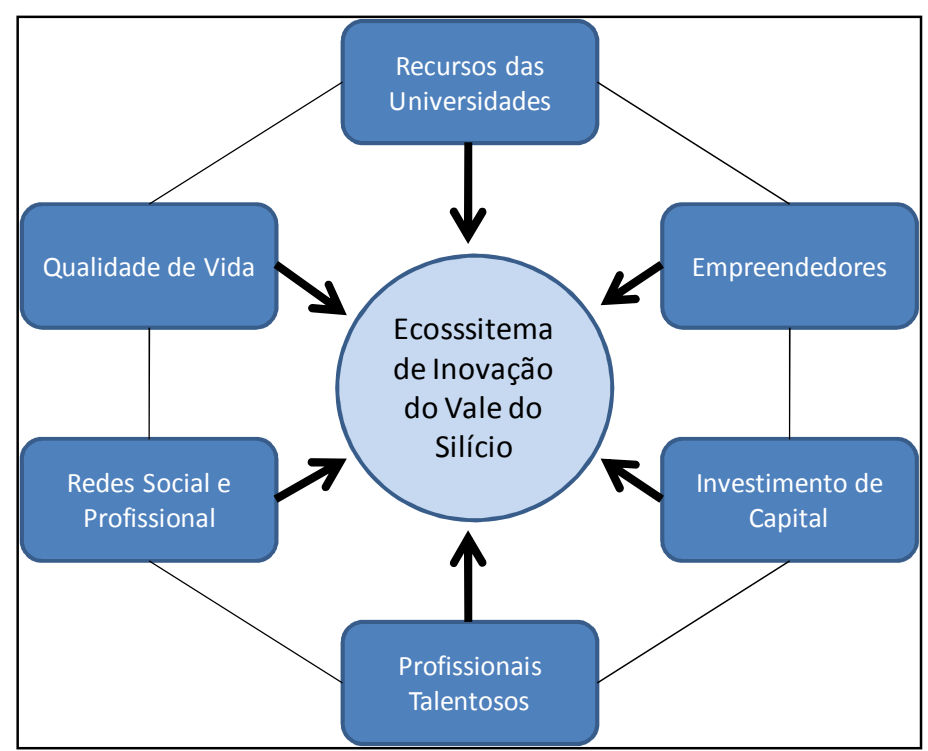

Figura 10: Elementos- Chave do Ecossistema de Inovação do Vale do Silício

No entanto, transferir simplesmente o conceito de Ecossistema de Inovação para - Brasil e acreditar que os resultados serão os mesmos do Vale do Silício pode ser um erro, pois as condições são diferentes. Dessa forma, é fundamental utilizar o conceito e adequá-lo à cultura brasileira e, principalmente, à da mineração brasileira.

Um dos principais problemas para o densenvolvimento dos ecossistemas de inovação no Brasil é a dificuldade de estabelecer parcerias baseadas no conceito de ganha-ganha. Normalmente, existe muito despreparo empresarial e disconfiança por parte dos profissionais talentosos e empreendedores e muita ganância e truculência por parte dos investidores de capital.

$\mathrm{Na}$ cultura brasileira, ainda existe muito conflito associado à ideia ultrapassada de que capital e trabalho são concorrentes, de que o empregador quer explorar o trabalhador e que o trabalhador quer enganar o empregador.

No entanto, para ser eficiente no desenvolvimento de inovações, é necessário um ambiente de efetivo comprometimento pessoal e de confiança. Nesse sentido, foi desenvolvido um modelo de relação pessoal entre liderança e liderados que está apresentado de forma esquemática na Figura 11. 


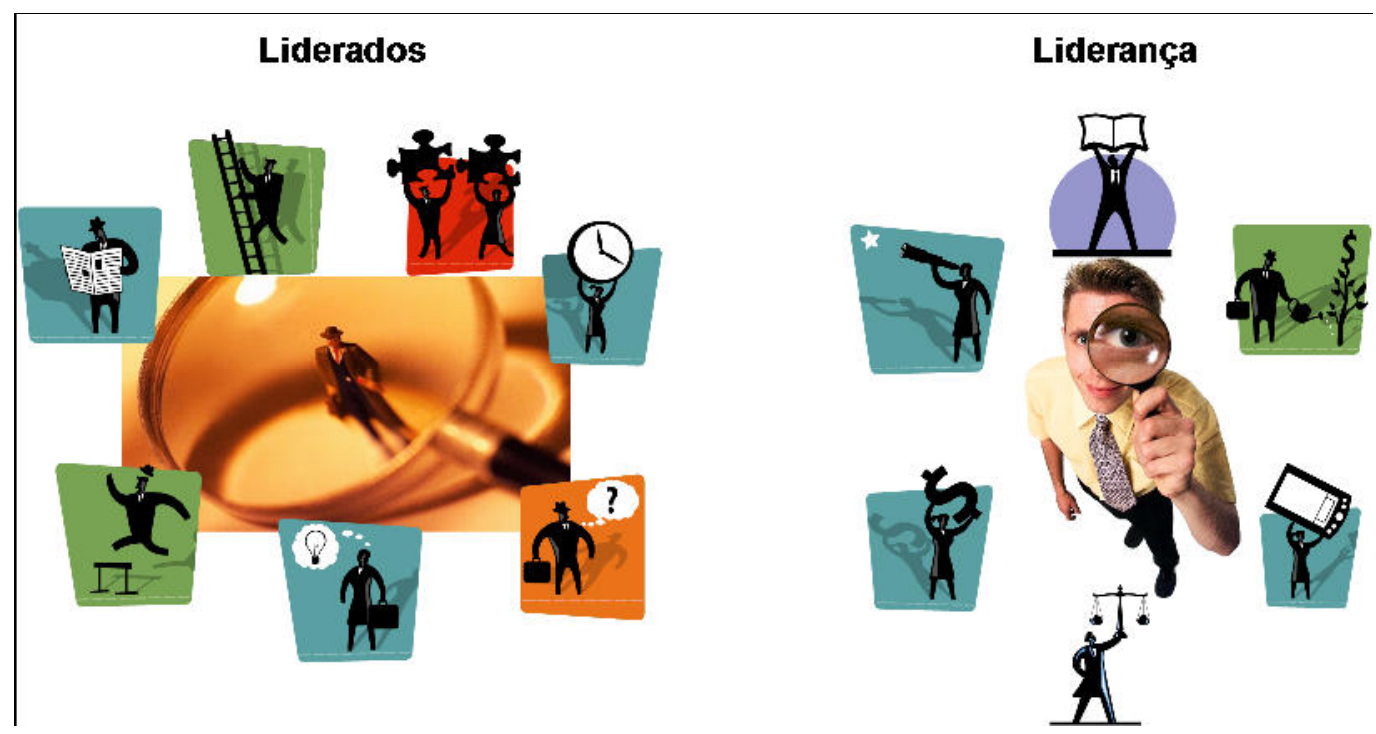

Figura 11: Modelo Esquemático de Relação Pessoal para Inovação

Esse esquema apresenta os liderados vistos sob uma nova lente, porém eles enxergam a liderança através dessa mesma lente, ou seja, se os liderados estão sendo cobrados para se capacitarem, apresentarem um nível superior de desempenho, atuarem em equipe, serem comprometidos, questionadores e criativos para superarem os resultados, a liderança deverá fornecer o caminho a ser trilhado, fornecer o conhecimento necessário, semear um ambiente positivo, fornecer as ferramentas, ser justa e estar disposta a compartilhar os resultados obtidos.

Para que o Ecossistema de Inovação seja eficiente, é necessário que exista a preocupação com resultados sustentáveis, porém, principalmente até que a cultura de inovação esteja estabelecida na organização, não pode ser deixado de lado o compromisso com resultados em curto prazo.

Apesar de isso parecer óbvio, o modelo de gestão dominante na mineração brasileira não privilegia a implementação da cultura de inovação, pois características, tais como excesso de controle, autoritarismo, pouca flexibilidade, aversão a risco, busca de culpados e visão restrita aos resultados de curto prazo, podem ser extremamente prejudiciais à formação de um Ecossistema de Inovação.

Além do modelo lógico de relação pessoal apresentado na Figura 10, temos 0 fato de o Brasil ser um país de origem latina, fato que torna a emoção muitas 
vezes mais importante que a lógica, por isso, é fundamental que a liderança se atente a garantir que uma série de características esteja presente no Ecossistema de Inovação. Algumas dessas características estão apresentadas na Figura 12.

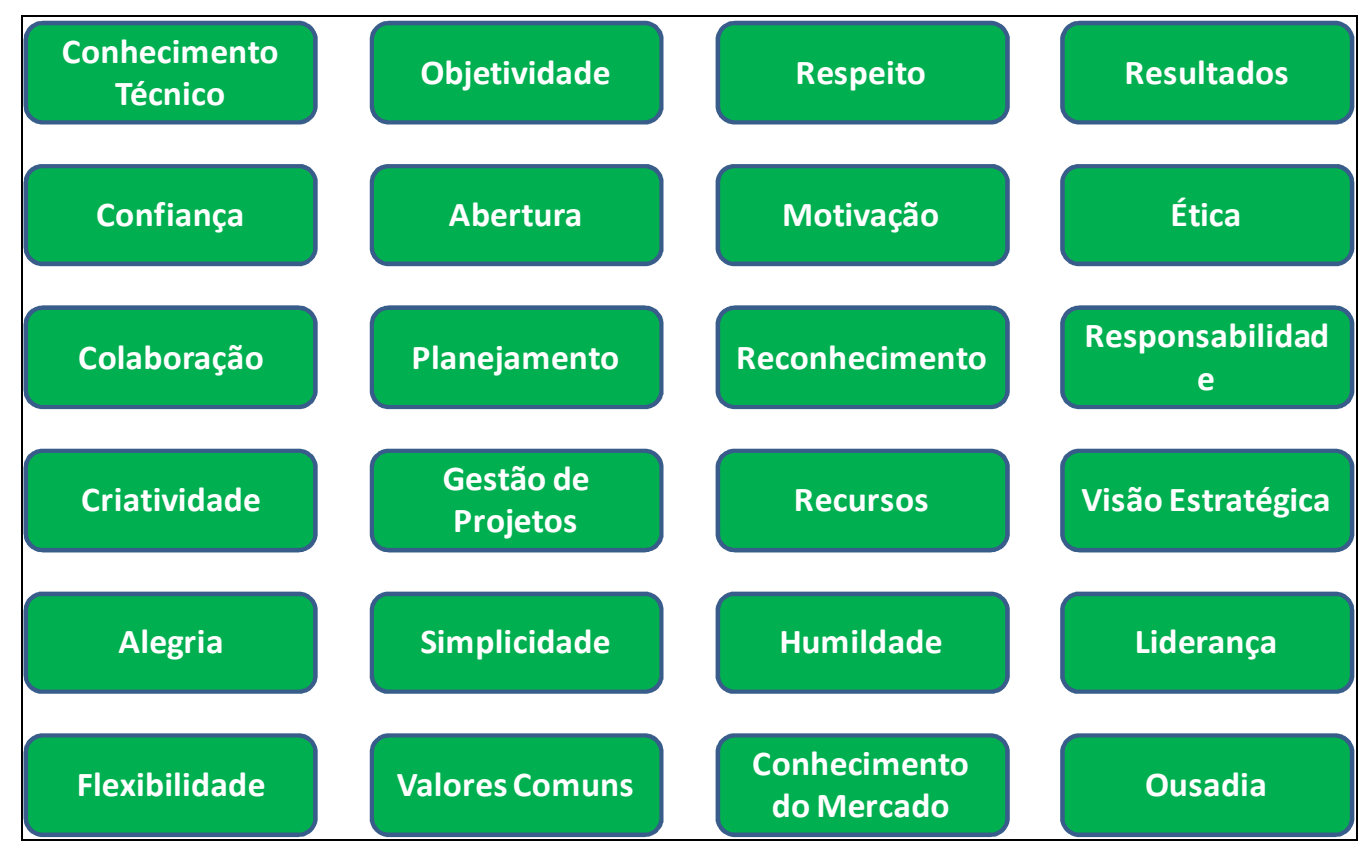

Figura 12: Características Necessárias para um Ecossistema de Inovação Eficiente

Além das questões pessoais, a integração entre as universidades e as empresas ainda é pequena e frágil, e um dos principais fatores dessa desarticulação, mais uma vez, é a desconfiança.

Em muitos casos, a universidade enxerga as empresas como oportunistas, que querem explorar o seu conhecimento sem o devido retorno, e as empresas avaliam que as universidades, apesar do reconhecido conhecimento, não possuem a objetividade e o comprometimento necessários para atender as suas demandas por resultados em curto prazo.

O governo brasileiro tem implementado uma série de condições para fomentar o desenvolvimento tecnológico, tais como criação de parques tecnológicos, financiamentos a fundo perdido, financiamentos subsidiados e incentivos fiscais, porém, mais do que a questão financeira, essas condições buscam contribuir para o desenvolvimento da cultura de inovação por meio de: 
- Estruturação de programas de PD\&I nas empresas;

- Parcerias entre universidades e empresas;

- Desenvolvimento da cultura de planejamento e gestão de projetos para inovação;

- Fortalecimento dos empreendedores através de parcerias com empresas de maior porte;

- Agilização de resultados por mais disponibilidade de recursos para PD\&l;

- Estabelecimentos de centros de referência em desenvolvimento tecnológico para fins específicos.

A Lei do Bem é um exemplo muito claro de como o governo brasileiro tem buscado fortalecer a inovação tecnológica no país. O conceito básico dessa lei pode ser observado no esquema apresentado na Figura 13, em que o estado fomenta a união entre o setor produtivo, as universidades e as empresas de engenharia por meio de financiamentos subsidiados e incentivos fiscais, permitindo que estes atuem em rede para agilizar o desenvolvimento sustentável do Brasil.

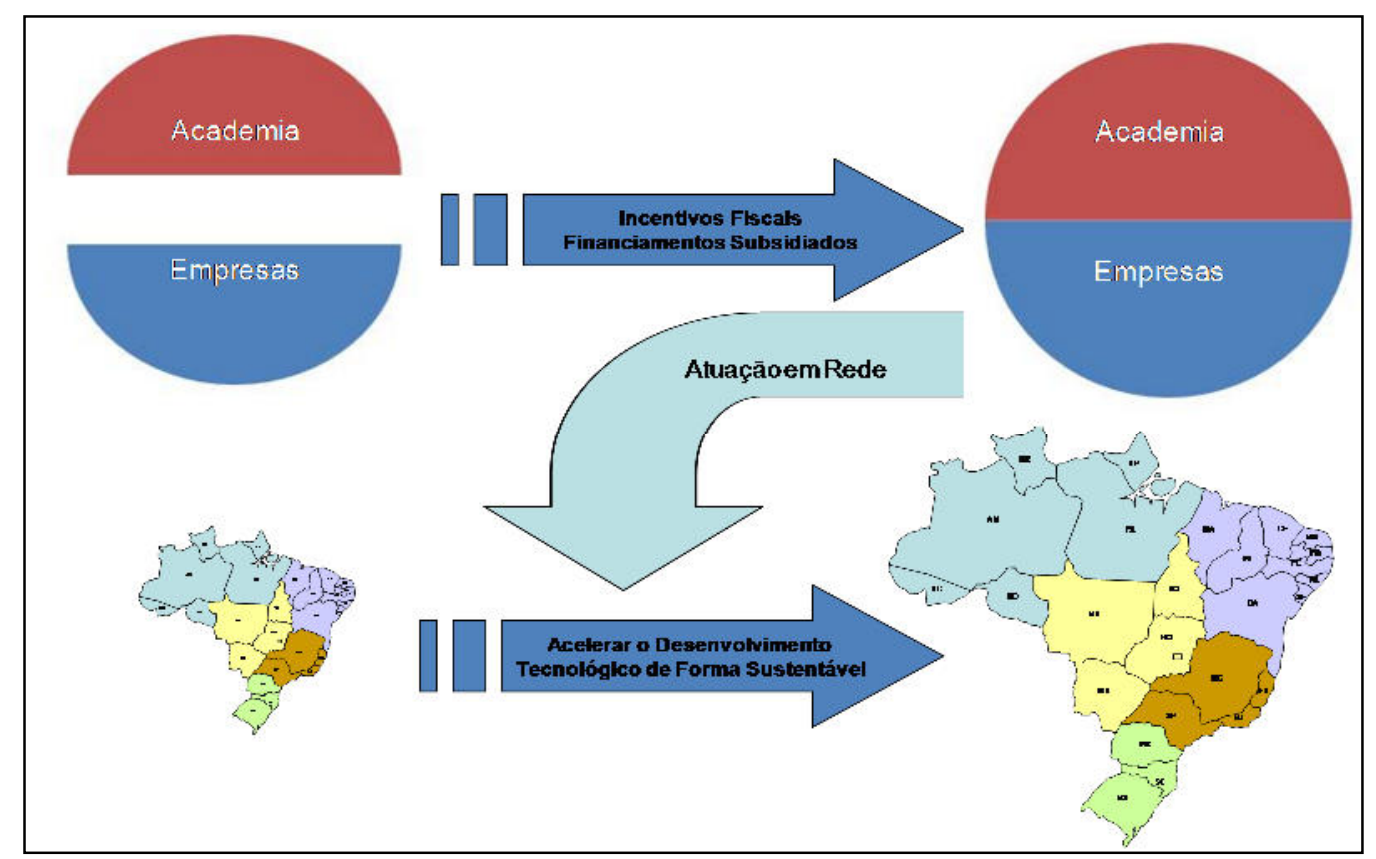

Figura 13: Objetivos da Lei do Bem

Pela Lei do Bem, o governo passa a seguinte mensagem: as empresas devem investir recursos que usariam para pagamento de impostos em ganho de 
competitividade por meio de projetos de inovação, ou seja, o Brasil abre mão de recursos de curto prazo para ganhar no médio e longo de forma sustentável.

Porém, mesmo que o Ecossistema de Inovação esteja muito bem estruturado, trabalhando de forma extremamente harmônica, é necessário que se tenha a visão que somente o desenvolvimento de novas tecnologias não será o suficiente para alavancar a competitividade do setor mineral brasileiro, pois os resultados das inovações estão associados a, pelo menos, três componentes: tecnologia, processos e pessoas, como apresentado na Figura 14.

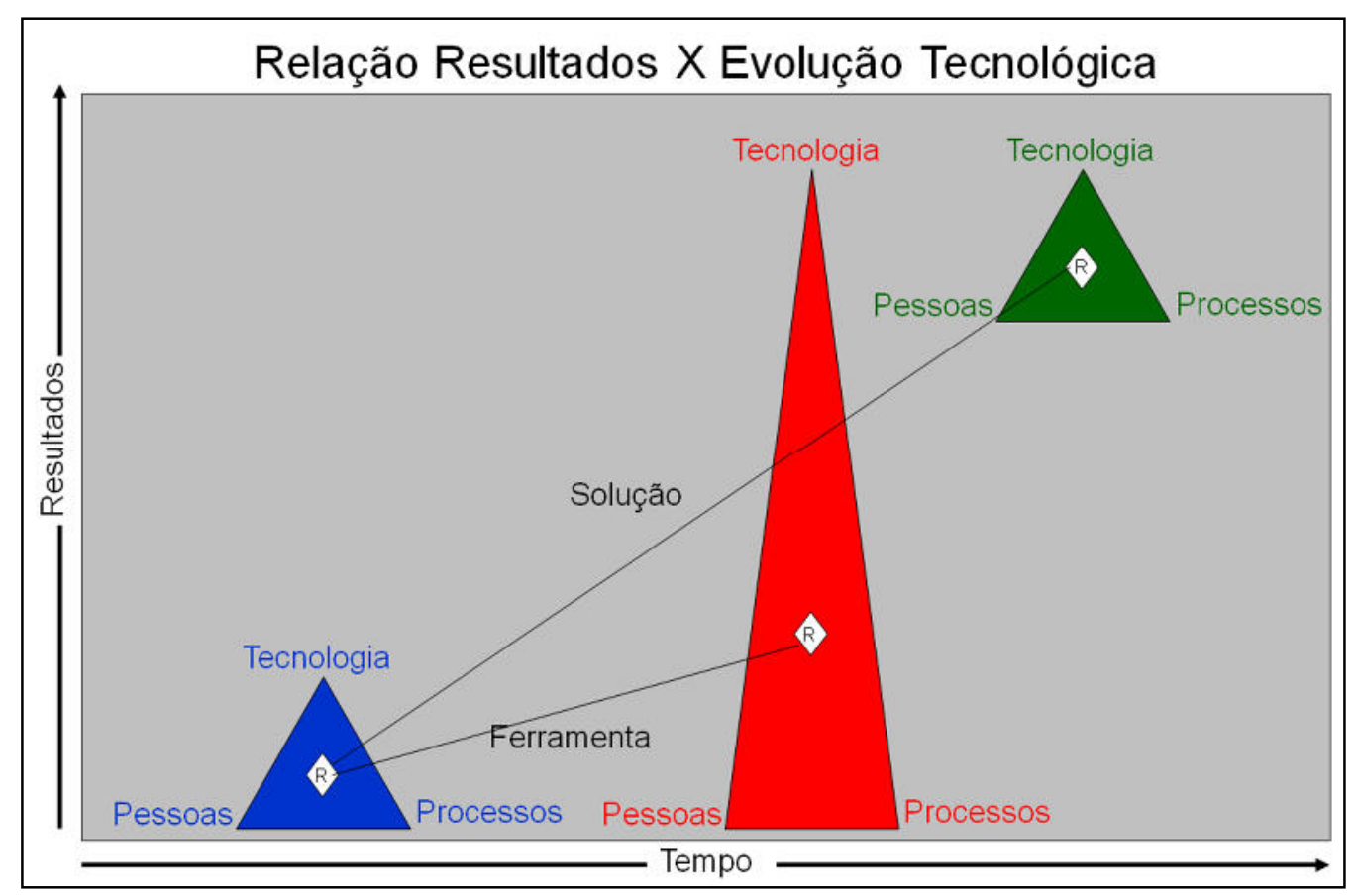

Figura 14: Resultados da Inovação e seus Componentes

Como apresentado na Figura 14, quando se desenvolve apenas uma nova tecnologia (os processos e as pessoas não acompanham a evolução), tem-se uma ferramenta, porém o resultado da inovação não atinge todo o seu potencial. Nesse caso, a evolução pode ser posterior, e a nova tecnologia pode demorar mais tempo para se solidificar no mercado ou não se estabelecer de forma competitiva.

Porém, se a inovação for desenvolvida de forma completa, o resultado será a solução, em que a evolução da tecnologia, dos processos e das pessoas ocorrerá de forma integrada, maximizando os resultados em menor espaço de tempo. Com isso, acredita-se que a disseminação da cultura de inovação em 
uma organização será fortalecida no sentido top-down, por meio da valorização dos resultados obtidos e, no bottom-up, pelo envolvimento dos funcionários em grandes desafios com o meio acadêmico e científico e pelo reconhecimento pelos resultados obtidos.

Em muitos casos, o desenvolvimento de uma solução para explorar um depósito mineral de forma inovadora pode ser caracterizado como um projeto de inovação, podendo usufruir de todos os incentivos associados, reduzindo os riscos e facilitando a viabilização de novos empreendimentos minerais.

\subsubsection{Oportunidades de Redução de Risco Financeiro}

Os mecanismos de financiamento disponíveis para inovação no Brasil são extremamente atraentes e podem ser divididos em cinco grupos:

- Financiamento a fundo perdido;

- Financiamento reembolsável subsidiado;

- Incentivo fiscal;

- Redução de investimento e custo operacional até a confirmação da viabilidade;

- Desoneração de remessa de lucros para o exterior.

\section{Financiamento a fundo perdido}

Existem vários meios de financiamento a fundo perdido para projetos de inovação (CNPq, FINEP, CAPES e fundações estaduais de apoio à pesquisa, como, por exemplo, FAPESP e FAPEMIG), no entanto, a apresentação dos projetos depende de editais de convocação. Os prazos de análise e a liberação dos recursos costumam ser mais longos, a burocracia ser maior e os recursos menores que os reembolsáveis. Em função das dificuldades, esse mecanismo não foi considerado para essa metodologia. 
Atualmente a única linha de financiamento subsidiado para inovação disponível no Brasil, que não sejam de editais, é pelo Programa Inova Brasil da FINEP. O BNDES até apresenta uma linha para financiar inovação, porém atualmente está direcionando essas operações para a FINEP.

Projetos de inovação bem estruturados podem ser financiados de forma bastante ágil, flexível e profissional. As condições dos financiamentos são extremamente atraentes e existe grande disponibilidade de recursos. As condições de financiamento do programa Inova Brasil da FINEP são a $s$ seguintes:

- Tipo de financiamento: reembolsável;

- Limites:

- Mínimo de $\mathrm{R} \$ 10$ milhões;

- Máximo depende do grupo empresarial;

- Taxa anual: TJLP menos 1,0\%;

- Prazo de carência de até 48 meses;

- Prazo total para amortização de até 120 meses;

- Participação: $90 \%$ do valor total do projeto.

A comparação dos mecanismos de financiamento para inovação pode ser observada de forma resumida na Figura 15.

\begin{tabular}{|l|c|c|c|}
\hline \multicolumn{1}{|c|}{ Pontos analisados } & $\begin{array}{c}\text { Financiamento } \\
\text { a Fundo Perdido }\end{array}$ & $\begin{array}{c}\text { Subvenção } \\
\text { Econômica }\end{array}$ & $\begin{array}{c}\text { Financiamento } \\
\text { Reembolsável }\end{array}$ \\
\hline Dificuldade de entrada & Alta & Alta & Média \\
\hline Volume de recursos & Baixo & Baixo & Alto \\
\hline Agilidade na liberação & Baixa & Baixa & Alta \\
\hline Burocracia & Alta & Alta & Média \\
\hline Incentivos Fiscais & Não & Não & Sim \\
\hline Custo Final do projeto & Baixo & Baixo & Baixo* \\
\hline
\end{tabular}

* Considerado com incentivos fiscais e antecipação de resultados

Figura 15: Mecanismos de Financiamento para Inovação 


\section{Incentivo fiscal}

A Lei do Bem trouxe a possibilidade de obtenção de diversos benefícios para as empresas que investem em pesquisas tecnológicas e inovação. Ela veio como um plano de inovação para o país, aumentando a competitividade da indústria nacional. A lei se aplica a todas as empresas, em qualquer área de atuação, que invistam em pesquisa e desenvolvimento para inovação ou aperfeiçoamento de produtos e processos (PEROBA \& CARPINETTI, 2009). Um ponto a ser ressaltado é que o processo é pouco burocrático, pois não necessita que a pessoa jurídica aprove previamente um projeto de pesquisa para aproveitamento dos incentivos fiscais.

Os incentivos reais previstos na lei, resumidamente, podem ser definidos como:

- Exclusão do lucro líquido e da base de cálculo da Contribuição Social Sobre o Lucro Líquido - CSLL, o valor correspondente de até $60 \%$ da soma dos dispêndios, classificados como despesas operacionais pela legislação do Imposto sobre a Renda da Pessoa Jurídica - IRPJ, realizados com P\&D no período;

- Até $20 \%$, no caso de incremento do número de pesquisadores dedicados à pesquisa e ao desenvolvimento contratados no ano de referência;

- Até $20 \%$, no caso de patente concedida ou cultivar registrado. Portanto, os incentivos supramencionados poderão chegar à dedução de $200 \%$ ( $100 \%$ das despesas $+60 \%$ pelo incentivo de realizar P\&D $+20 \%$ pelo aumento de pesquisadores $+20 \%$ pela concessão de patente ou registro de cultivar).

- Redução de $50 \%$ do IPI incidente sobre equipamentos, máquinas, aparelhos e instrumentos importados para P\&D;

- Depreciação e amortização acelerada de equipamentos e bens intangíveis, respectivamente para P\&D;

- Redução a zero da alíquota do IR nas remessas efetuadas para o exterior, destinadas ao registro e manutenção de marcas, patentes e cultivares. 


\section{Redução de investimento e custo operacional até a confirmação da viabilidade}

Muitas das empresas não se enxergam como inovadoras e por isso não se beneficiam dos incentivos para fomentar as atividades de PD\&I no Brasil. Dessa forma, elas desenvolvem muitos projetos de melhorias e até de pesquisa tecnológica e inovação como sendo atividade operacional ou investimento corrente.

$\mathrm{Na}$ mineração, isso é muito mais crítico, pois, se for considerado que grande parte dos novos empreendimentos minerais necessita de pesquisa e desenvolvimento para comprovar a viabilidade do investimento e que, em muitos casos, é necessário o desenvolvimento de inovações para essa viabilização, as empresas consideram essas atividades como investimento ou custo operacional, restringindo os investimentos e assumindo maiores riscos.

No entanto, se as empresas de mineração financiarem muito de seus investimentos como projetos de inovação e ainda obtiverem os incentivos fiscais associados, o desenvolvimento de novos empreendimentos ficará menos oneroso, os riscos associados também serão reduzidos e isso contribuirá para o aproveitamento do enorme potencial mineral brasileiro.

\section{Desoneração de remessa de lucros para o exterior}

Além de todos os benefícios já comentados para fomentar a inovação tecnológica no Brasil, as empresas estrangeiras podem se beneficiar de forma indireta e isso é muito interessante.

Essas empresas podem transferir suas áreas de PD\&l para o Brasil, desonerando a matriz e possibilitando o aproveitamento dos financiamentos subsidiados e dos incentivos fiscais. Mesmo que o financiamento no exterior seja mais atrativo, é interessante financiar uma pequena parte do projeto na FINEP para "certificar" o projeto como inovação e assim conseguir aplicar os 
recursos que seriam utilizados para pagamento de impostos no desenvolvimento da empresa.

Dessa forma, além de fortalecer o caixa na matriz, obter financiamento subsidiado e deixar de pagar impostos no Brasil, a empresa exportará tecnologia e conhecimento desenvolvidos aqui, que não são taxados, reduzindo a remessa de lucros e, consequentemente, os impostos associados. Ou seja, no balanço geral, além de o governo brasileiro transmitir a mensagem para as empresas pagarem menos impostos investindo na sua competitividade, está falando para as estrangeiras que elas venham desenvolver tecnologia e conhecimento científico no Brasil e que paguem menos impostos ainda. Como uma das barreiras aos investimentos no país é a carga tributária, esses mecanismos reduzem em muito essa barreira, favorecendo o investimento em empreendimentos inovadores.

É importante ressaltar que tal estratégia é muito benéfica em termos econômicos para as empresas estrangeiras, mas também é muito interessante para o Brasil, pois estará sendo transferido um investimento nobre para o país, pois gera competência técnica e massa crítica em PD\&l, além de desenvolver as universidades locais a partir do envolvimento em tais projetos.

Quando foi identificada a possibilidade desse tratamento financeiro, foi considerada a hipótese de não explicitá-lo nesse trabalho, no sentido de evitar uma possível interpretação conservadora, protecionista e corporativista, que poderia despertar restrições a tal procedimento por parte das autoridades. No entanto, como já foi entendido que a Lei do Bem é uma iniciativa construtiva e integradora, que as autoridades quando a implementaram estavam buscando levar o Brasil a um novo patamar de competitividade, chegou-se à conclusão de que a informação deveria ser a mais transparente possível e que as forças para modernizar a economia brasileira seriam muito superiores às que queriam mantê-la no atraso a que estamos acostumados.

\subsubsection{Projeto Expandido}


Conforme apresentado na Figura 16, o projeto de inovação não se resume ao trabalho de laboratório, ele apresenta várias fases para possibilitar que seu resultado seja efetivamente considerado um sucesso.

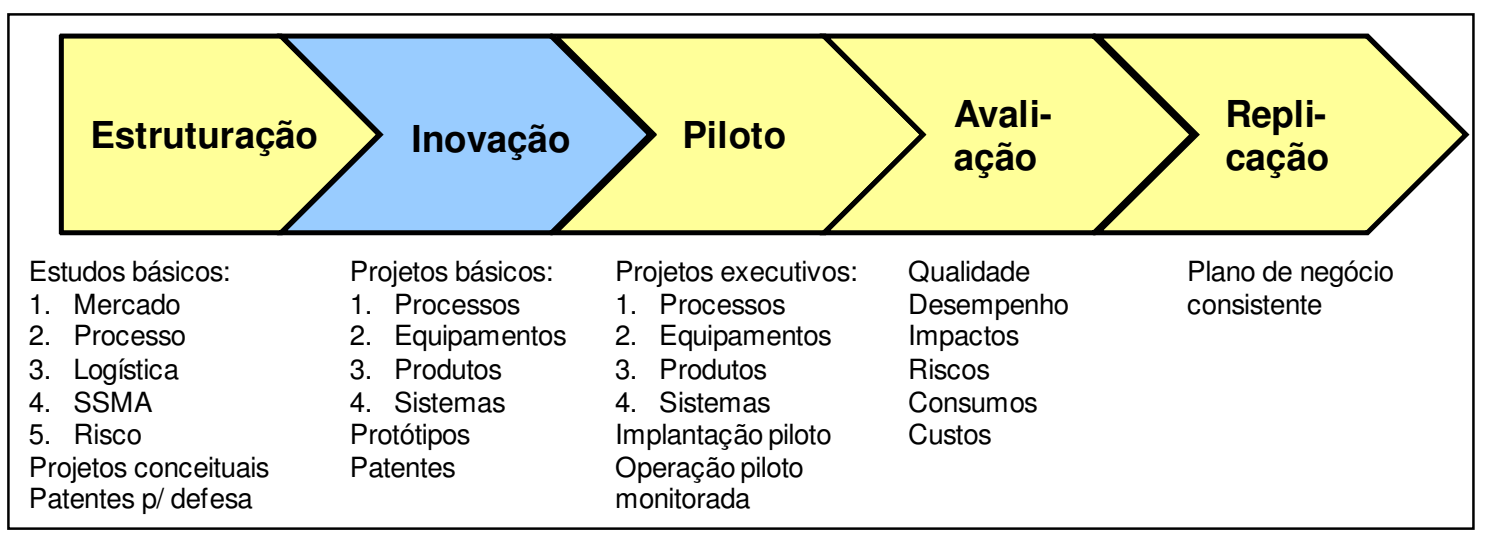

Figura 16: Projeto Expandido

O detalhamento dessas fases é assim apresentado:

1. Estruturação - são efetuados todos os estudos necessários para orientar o desenvolvimento de uma solução de forma rápida, consistente e eficiente, ou seja, são levantadas as tecnologias que podem contribuir para a solução que está sendo desenvolvida (não reinventar a roda). Além disso, são estudadas a legislação, as normas técnicas e as publicações que possam contribuir para que a inovação a ser desenvolvida esteja alinhada ao ambiente onde será aplicada. Nessa fase, é desenvolvido o projeto conceitual da inovação e são definidas as patentes de defesa que devem ser registradas.

2. Inovação - é onde são efetivamente desenvolvidas as inovações, elaborando os projetos dos protótipos, construindo-os, testando-os, aperfeiçoando-os e avaliando em laboratório os desempenhos conseguidos. Com base nos resultados obtidos, é que será definida a viabilidade de registro de patentes e do desenvolvimento de pilotos.

3. Piloto - nessa fase, é desenvolvida, implantada e operada a instalaçãopiloto que possibilitará a validação das premissas estabelecidas na fase anterior, a otimização de processo e o desenvolvimento de produtos. A planta-piloto deverá possuir uma escala que permita uma operação cujos resultados sejam representativos de uma planta industrial. 
4. Avaliação - essa fase segue em paralelo com a operação-piloto, porém começa logo após o seu início e termina depois do seu fim. Nela são avaliadas as condições operacionais para produção e validados os desempenhos dos produtos desenvolvidos. Ou seja, são obtidas as informações consistentes sobre o desempenho dos processos produtivos, os consumos e os desgastes associados, além disso, são verificados os desempenhos dos produtos em condições normais de utilização, gerando os argumentos de venda para desenvolvimento de mercado.

5. Replicação - após todas as demais fases, será possível avaliar, de forma consistente, qual o nível de competitividade, quais os investimentos necessários para introduzi-la no mercado e qual o potencial de retorno da inovação desenvolvida. Com base no conhecimento adquirido, é possível desenvolver um plano de negócio para aprovação dos investimentos para implementação da inovação ou para buscar investidores para viabilizá-la.

No caso da mineração, o projeto expandido pode ser apresentado de forma mais específica, pois os depósitos minerais apresentam características que podem torná-los únicos e que necessitem de desenvolvimento de soluções próprias para o seu melhor aproveitamento. Dessa forma, em muitos casos, o projeto expandido na mineração pode ser apresentado conforme a Figura 17.

\section{Projeto Expandido}

O conceito de projeto "expandido" (Fonte: De Tomi et al., 2010)

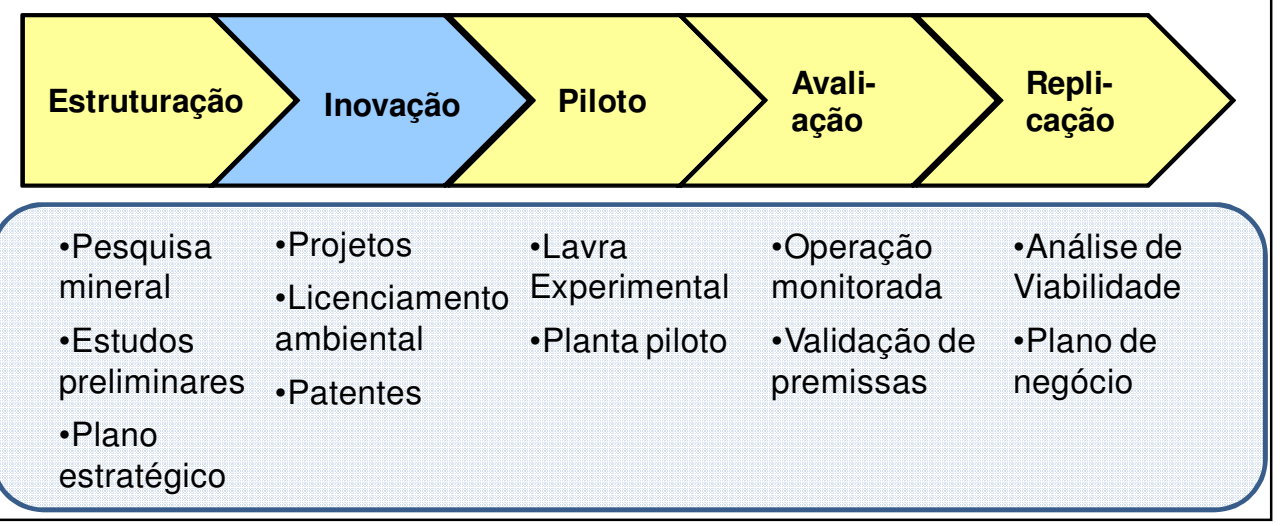

Figura 17: Projeto Expandido Aplicado à Mineração 
Um dos maiores desafios existentes na utilização da metodologia de gestão de inovação proposta é enxergar o projeto expandido como uma oportunidade de fazer mais com menos. O modelo mental comum busca reduzir e simplificar os projetos de PD\&I para reduzir os riscos, concentrando os esforços na fase de Inovação, no entanto, muitos dos desafios e riscos não são considerados, acarretando em projeto subdimensionados para a superação dos desafios no prazo planejado, ou extensão dos prazos e atraso na obtenção dos resultados, ou identificação de riscos ocultos na fase de implementação da inovação, reduzindo os ganhos ou até inviabilizando a inovação.

Quando o projeto expandido é considerado na metodologia de gestão de inovação proposta, a forma de pensar no projeto deve ser contrária ao padrão atualmente utilizado, pois é interessante ampliar o escopo do projeto e inserir as oportunidades de forma mais abrangente, pois o governo reduz o seu risco por meio de financiamento subsidiado e incentivos fiscais.

\subsection{Proposta de Metodologia de Gestão de Inovação para a Mineração Brasileira}

Já existem muitas iniciativas para auxiliar o desenvolvimento de inovações, porém grande parte delas se concentra em ambientes com a cultura de inovação já estabelecida, onde o grande desafio é desenvolver a criatividade para gerar inovações radicais que permitam aproveitar as grandes oportunidades de forma estruturada, com grande organização e disciplina, com maior importância para resultados sustentáveis do que para os de curto prazo.

Porém, a realidade do Brasil não é esta, e com a mineração brasileira não é diferente. Dessa forma, necessitamos buscar um caminho diferente, pois, em função do baixo nível de competitividade das empresas brasileiras, as oportunidades de inovações incrementais são enormes, a criatividade e a vontade de contribuir do povo são elevadas, no entanto, não se tem acesso à alta tecnologia, o povo é despreparado, desarticulado e indisciplinado, e as organizações, na sua grande maioria, são imediatistas, autoritárias, cartoriais e gananciosas. 
Essa realidade é fortemente desfavorável ao estabelecimento de um ambiente inovador, porém em função da sobrevivência da economia brasileira, a mudança se tornou urgente, no entanto, como existem muitas oportunidades a serem desenvolvidas para promover o ganho de competitividade das empresas que atuam no Brasil, foi criado um caminho para facilitar o desenvolvimento de projetos de inovação que sirvam de exemplo para outras empresas.

A base da proposta desenvolvida neste trabalho foi a Metodologia i9 de Gestão de Inovação*, que foi estruturada para facilitar o desenvolvimento de inovações de interesse das empresas, que podem ser radicais ou incrementais, mas que promovam elevados ganhos em um prazo de tempo razoável. Isso visa possibilitar o desenvolvimento da cultura de inovação através de exemplos positivos que contribuam fortemente para o ganho de competitividade das empresas que a adotarem, conforme apresentado na Figura 18.

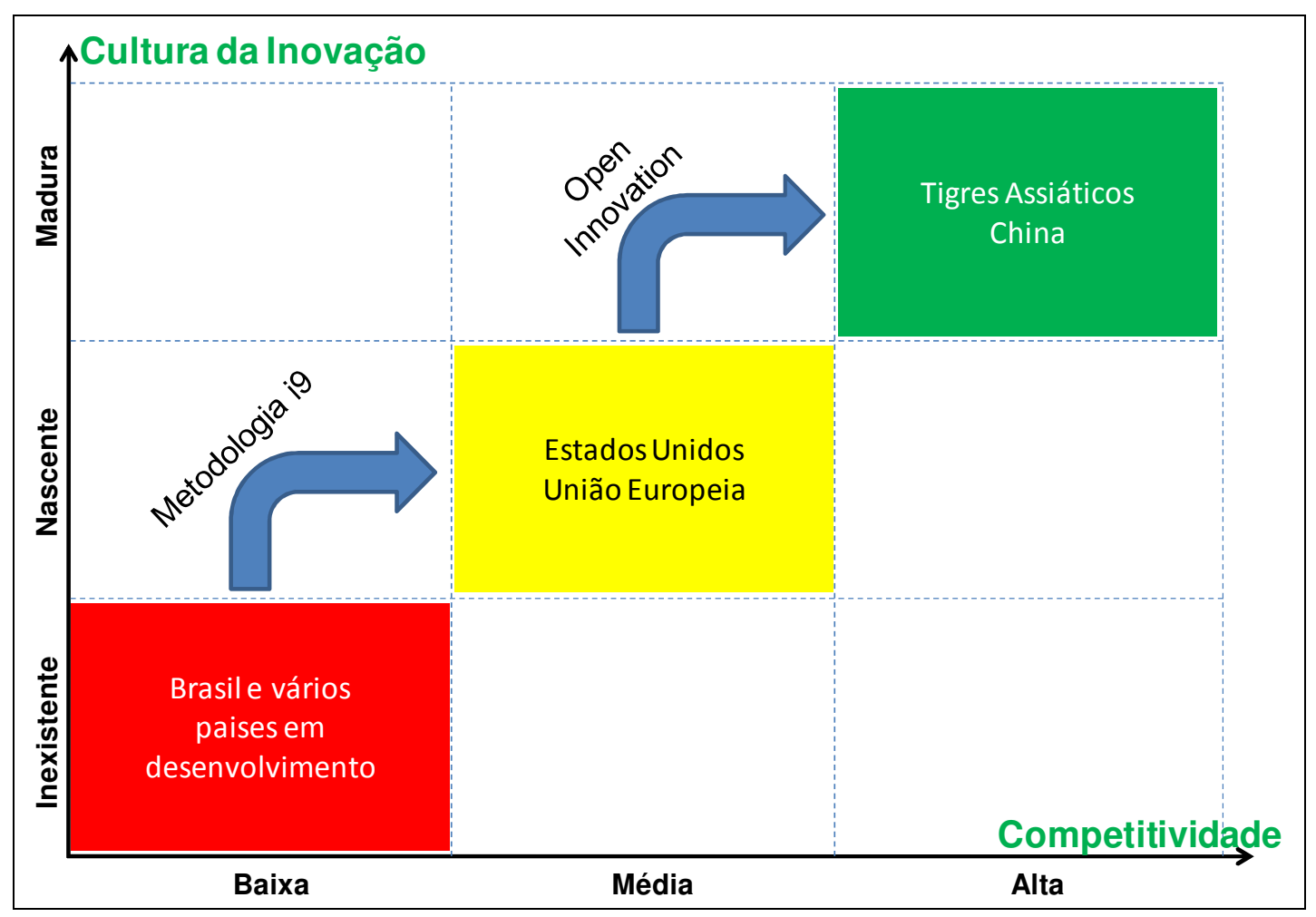

Figura 18: Cultura de Inovação e Competitividade

*NOTA: A metodologia i9 vem sendo desenvolvida profissionalmente pelo autor

A Metodologia proposta busca orientar empresas, universidades, empreendedores e empresas de engenharia para desenvolverem projetos de 
inovação com elevado padrão de sucesso. Ela é de formada de 4 pilares e está apresentada de forma esquemática na Figura 19.

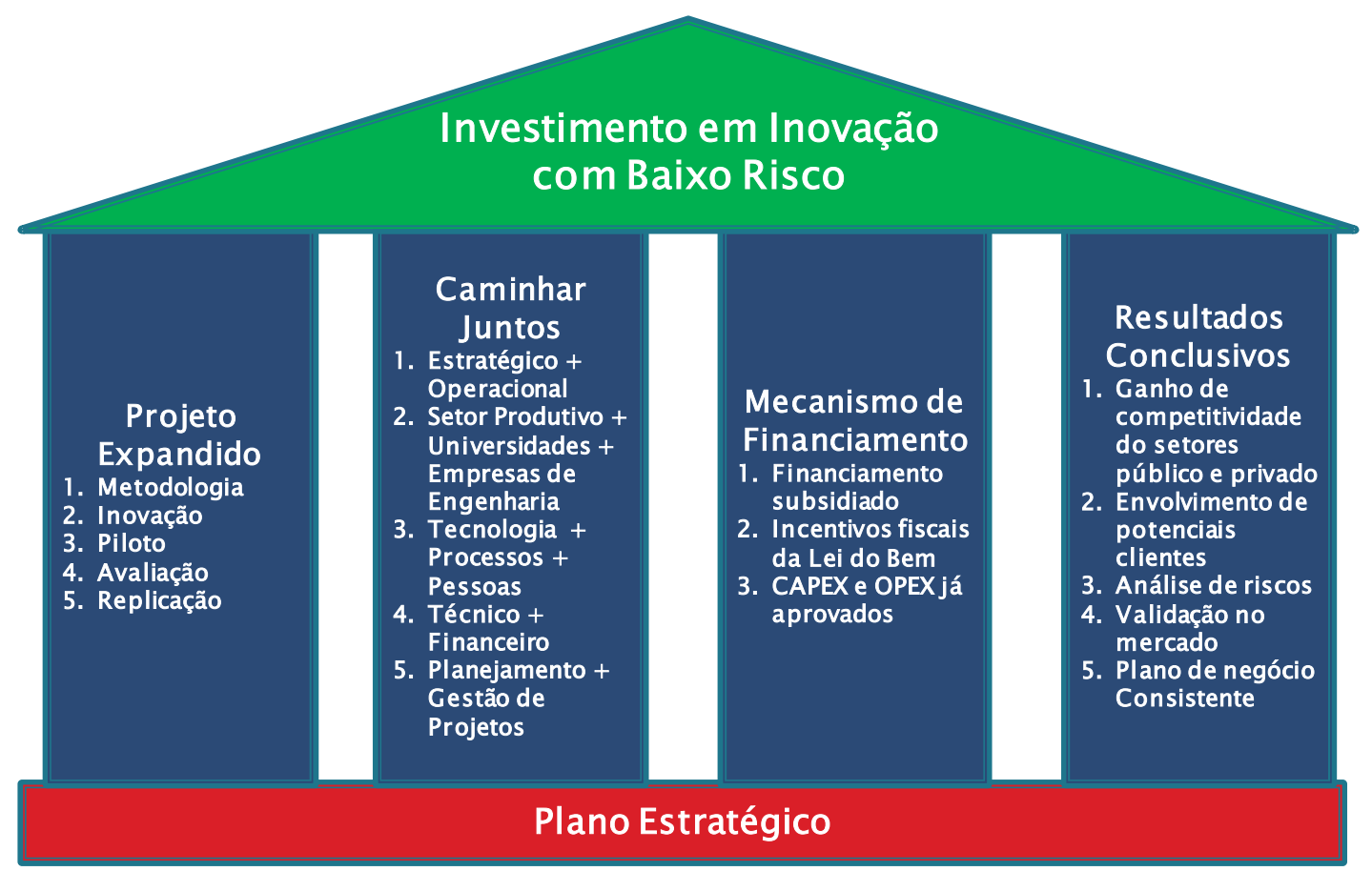

Figura 19: Metodologia proposta

A maior parte dos pontos considerados na Metodologia proposta já foi explicada anteriormente, porém existem alguns itens citados na Figura 19 que necessitam ser esclarecidos:

1. Caminhar Juntos: na realidade, significa estabelecer parcerias que possam atender todas as demandas dos projetos.

a. Estratégico + Operacional: os projetos de inovação necessitam estar alinhados aos desafios estratégicos das empresas, pois os desafios operacionais costumam exigir respostas muito rápidas e a estruturação dos projetos, segundo a metodologia proposta, necessitará de prazos que podem não atender essas demandas.

b. Técnico + Financeiro: não adianta o projeto ser um sucesso técnico se o orçamento estiver estourado, da mesma forma que o projeto esteja dentro do orçamento, mas os resultados técnicos sejam um 
fiasco. O sucesso necessita que os dois sejam tratados com o mesmo compromisso.

c. Planejamento + Gestão de Projetos: a chave para desenvolver projetos de grande amplitude, com comprometimento de altos valores, está em um plano bem elaborado e uma execução bem gerida, no entanto, no caso de inovação, é necessário que haja flexibilidade, pois, durante o desenvolvimento do projeto, é normal que ocorra um processo de aprendizado que acarretará adequação do plano e ajustes de rota na execução.

2. Resultados Conclusivos: como a estratégia adotada para fortalecimento da cultura de inovação é que investir em inovação contribui fortemente para o ganho de competitividade das empresas, os projetos devem ser estruturados para atingir resultados conclusivos sobre a viabilidade ou não de se investir em uma inovação. Projetos não conclusivos geram mais desconfiança e resistência ao investimento em inovação.

a. Ganho de competitividade dos setores público e privado: o envolvimento de professores, pesquisadores e alunos das universidades e centros de pesquisa, além de contribuir para soluções inovadoras nas empresas, também contribui para melhoria dos cursos, pois a aproximação entre as universidades e as empresas permite o desenvolvimento dos envolvidos por meio de aplicação real.

b. Envolvimento de potenciais clientes: os potenciais clientes podem ser envolvidos nos projetos, contribuindo na solução a ser desenvolvida, validando a aplicabilidade das propostas e desempenho dos produtos desenvolvidos. Essa abordagem contribui com o marketing do novo negócio, permite calibrar previamente a aceitação no mercado e pode até gerar contratos ainda na fase de desenvolvimento. Tudo isso com financiamento subsidiado e com incentivos fiscais. 
c. Análise de riscos: normalmente os riscos de novos negócios são detalhados na sua operação após grande parte dos investimentos terem sido efetuados, pois, como os recursos para desenvolvimento do projeto são escassos, várias situações não são profundamente avaliadas, gerando supresas que podem acarretar na inviabilidade da continuidade do novo negócio. Com a metodologia de gestão de inovação, muitos desses riscos serão avaliados na fase de projeto, reduzindo os riscos futuros.

d. Validação no mercado: além do envolvimento dos clientes e da análise de risco, as soluções desenvolvidas podem ser testadas em campo em condições normais, sendo que custos foram pagos pelo projeto e, no caso de sucesso, o cliente poderá pagar pelo desempenho obtido. Isso pode facilitar muito a abertura de mercado para novos produtos.

e. Plano de negócio consistente: abordagem da metodologia proposta permite que as informações sejam muito mais consistentes, os riscos identificados e controlados preliminarmente, dando mais segurança na avaliação da viabilidade de implantação e na definição dos investimentos associados a um novo negócio.

Para a implantação da metodologia proposta em uma empresa, deve-se levar em consideração os seguintes passos.

\subsubsection{Planejamento Estratégico}

O planejamento estratégico de PD\&l deve estar alinhado aos objetivos estratégicos da empresa. Caso a empresa não o possua, o plano estratégico de PD\&I deve ser estabelecido considerando os seguintes pontos:
a. Desafios da empresa;
b. Tecnologias que podem contribuir para superação dos desafios;
c. Propostas de soluções a serem desenvolvidas; 

d. Prioridade das soluções;
e. Capacidade de investimento no PD\&I;
f. Seleção dos projetos a serem avaliados.

Um ponto fundamental para avançar no processo é a definição da estrutura de PD\&l e de como ele deverá atuar.

Obs.: A presente metodologia considerou que as empresas já possuem várias propostas de projetos de inovação e que, neste momento, o grande desafio não é aumentar a carteira de propostas, mas sim estruturá-las para o desenvolvimento efetivo, contribuindo forte e rapidamente para o ganho de competitividade da empresa.

Como sugestão para avaliação preliminar das oportunidades de projetos a serem desenvolvidas, foi elaborada a Tabela 8.

Tabela 8: Tabela de Avaliação das Propostas de Projetos de Inovação

\begin{tabular}{|c|c|c|c|c|c|}
\hline \multicolumn{6}{|c|}{ Tabela de Avaliação das Propostas de Projetos de Inovação } \\
\hline \multirow[b]{2}{*}{ Item } & \multirow[b]{2}{*}{ Projeto de Inovação } & \multirow[b]{2}{*}{ Pontos-Chave } & \multirow[b]{2}{*}{ Esforçoo } & \multicolumn{2}{|c|}{ Retorno } \\
\hline & & & & Valor & $\Delta \mathrm{T}$ \\
\hline 1 & & & & & \\
\hline 2 & & & & & \\
\hline 3 & & & & & \\
\hline 4 & & & & & \\
\hline 5 & & & & & \\
\hline 6 & & & & & \\
\hline 7 & & & & & \\
\hline 8 & & & & & \\
\hline 9 & & & & & \\
\hline 10 & & & & & \\
\hline
\end{tabular}

Com o sucesso na estruturação do PD\&I, a tendência é que a carteira de projetos amplie em consequência da nova cultura desenvolvida, de mais capacitação da equipe, de mais rede de relacionamento e de mais disponibilidade de recursos. 


\subsubsection{Apresentação das Propostas de Projetos}

Nessa etapa, deverá ser efetuado o workshop inicial do programa de PD\&I, em que, além da capacitação das pessoas selecionadas sobre a metodologia implantada, serão transmitidos pela liderança de empresa os desafios estratégicos, os resultados esperados pela atuação do PD\&I e a importância da participação de todos de forma construtiva.

O objetivo é que, ao término do workshop, as equipes já possuam o escopo expandido dos projetos que desejem apresentar propostas.

As propostas de projetos deverão ser apresentadas declarando, de forma preliminar, os objetivos, o caráter inovador, o roteiro de desenvolvimento, os recursos necessários (humanos, materiais e tecnológicos), o cronograma, os riscos envolvidos, os mecanismos de financiamento, os resultados esperados e a viabilidade de desenvolvimento. Como orientação para essa etapa, foi desenvolvido o formulário Proposta de Projeto de Inovação apresentado a seguir.

\begin{tabular}{|l|l|}
\hline \multicolumn{2}{|c|}{ Proposta de Projeto de Inovação } \\
\hline $\begin{array}{l}\text { Título do } \\
\text { Projeto }\end{array}$ & \\
\hline Ponto-focal & $\begin{array}{l}\text { (Descrição resumida do projeto e sua relação com as metas globais da } \\
\text { carteira de projetos de inovação da Ultragaz) }\end{array}$ \\
\hline Descrição & $\begin{array}{l}\text { (Especificar se é desenvolvimento de novo processo ou de novo } \\
\text { produto, ou se é uma nova aplicação para um determinado produto ou } \\
\text { processo.) } \\
\text { (Aprox. } 3 \text { linhas) }\end{array}$ \\
\hline Inovador
\end{tabular}




\begin{tabular}{|l|l|}
\hline $\begin{array}{l}\text { Objetivos } \\
\text { Principais }\end{array}$ & $\begin{array}{l}\text { (Apenas bullet-points, começar as frases com VERBOS.) } \\
\text { (Relacionar, quando possível, com os objetivos globais da carteira de } \\
\text { projetos.) }\end{array}$ \\
\hline $\begin{array}{l}\text { Escopo } \\
\text { Resumido }\end{array}$ & $\begin{array}{l}\text { (Apenas itens numerados) } \\
\text { (A numeração deve corresponder à planilha do subprojeto.) }\end{array}$ \\
\hline $\begin{array}{l}\text { Metas \& } \\
\text { Indicador as frases com VERBOS.) }\end{array}$ \\
\hline Mercado & \\
\hline Produtos & (Apenas ITENS-DE-ENTREGA, i.e., itens tangíveis) \\
\hline
\end{tabular}

\subsubsection{Seleção das Propostas de Projetos}

Com as propostas de projetos refinadas, deverá ser efetuado um workshop com a alta direção da empresa para apresentação das propostas e esclarecimento de dúvidas. As propostas deverão ser revisadas, considerando as sugestões, as críticas e os comentários.

Uma situação importante que pode ocorrer no workshop é a identificação de sinergias com outros projetos, podendo até resultar em junção de alguns. O lado contrário também pode ocorrer, ou seja, um projeto ser desmembrado em vários.

Com o nivelamento das propostas de projetos de inovação e do conhecimento da alta direção, a área de PD\&I deverá resumir o conteúdo das várias propostas para facilitar a alta direção na avaliação da carteira de projetos que deverá ser desenvolvida.

Para orientar a execução dessa etapa, pode-se utilizar novamente a Tabela de Avaliação das Propostas de Projetos de Inovação apresentada no item 3.3.1., onde serão selecionados os projetos a serem desenvolvidos e a função dos desafios estratégicos, da análise de viabilidade e da capacidade de investimento. 
Após a definição dos projetos a serem desenvolvidos, deverá ser definida a estratégia de obtenção do financiamento para os projetos isolados ou carteira de projetos.

\subsubsection{Estruturação do Plano de Execução dos Projetos}

Os projetos aprovados para desenvolvimento deverão ser detalhados nesta sequência:

- Definição do escopo expandido em atividades detalhadas;

- Definição dos itens de entrega associados a cada atividade contida no escopo detalhado;

- Definição dos responsáveis por cada item de entrega do projeto;

- Estimativa do período de execução de cada atividade detalhada;

- Estimativa da quantidade de recursos necessários para cada item de entrega;

- Definição do custo unitário de cada recurso utilizado no projeto;

- Estimativa dos custos associados a cada item de entrega do projeto;

- Classificação dos custos de cada atividade do projeto de acordo com a classificação da instituição financiadora:

- Obras civis/Instalações

- Equipamentos nacionais

- Equipamentos importados

- Softwares

- Matérias-primas

- Equipe própria

- Treinamentos

- Serviços de consultoria

- Serviços de terceiros

- Viagens/Diárias

- Outros

- Distribuição ao longo do tempo das quantidades de recursos utilizados em cada item de entrega do projeto. 
Durante a estruturação da execução do projeto, é normal que sejam identificadas demandas que não haviam sido consideradas inicialmente e que o orçamento final fique maior que o original. Por isso, pode ser necessária mais uma rodada de avaliação do plano estratégico de PD\&I para validar os projetos que farão parte da solicitação do financiamento na instituição financiadora.

\subsubsection{Obtenção do Financiamento Subsidiado para a Inovação}

O financiamento reembolsável do programa Inova Brasil da FINEP apresenta em 2013 as seguintes condições:

- Financiamento de até $90 \%$ do projeto;

- Taxa anual de TJLP menos $1 \%$;

- Prazo de carência de até 48 meses;

- Prazo para amortização de até 120 meses da contratação.

\subsection{6- Acompanhamento do Projeto}

O acompanhamento da execução do projeto pela instituição financiadora ocorre semestralmente ou se houver atrasos no cronograma, quando, no mínimo, $80 \%$ dos recursos liberados já tenham sido consumidos. Para esse acompanhamento, serão utilizados dois relatórios: um técnico e outro financeiro.

Um dos pontos importantes da atuação da instituição financiadora na gestão de recursos de fomento ao desenvolvimento tecnológico e da inovação é a percepção de que, durante o desenvolvimento desses projetos, ocorra um processo de aprendizado que normalmente acarreta na mudança de rota. Dessa forma, apresenta elevada flexibilidade nas alterações de estratégia e de escopo dos projetos, desde que não se fuja dos objetivos acordados na contratação do financiamento.

Portanto, é importante ressaltar os seguintes pontos na linha de financiamento da proposta: 
1. As aprovações dos relatórios semestrais de acompanhamento serão certificados pelo $\mathrm{MCTI}$ de que os projetos foram adequadamente executados e de que a contabilidade deles está de acordo com as normas vigentes.

2. Com os certificados da instituição de fomento de que o projeto é de inovação e de que a execução e a contabilidade estão de acordo com as normas do MCTI, a obtenção dos incentivos fiscais da Lei do Bem ocorre de forma extremamente segura.

3. Além das grandes facilidades financeiras, foram considerados fundamentais para o desenvolvimento da cultura de inovação e ganho de competitividade das empresas os seguintes pontos:

a. Planejamento efetivo dos projetos e sua gestão sistêmica;

b. Desenvolvimento de parcerias com universidades, centros de pesquisa e empresas de engenharia;

c. Gestão participativa com delegação estruturada;

d. Visão abrangente dos desafios, com aplicação do conceito do projeto expandido, permitindo que a disponibilidade de recursos seja adequada aos objetivos a serem atingidos, reduzindo os prazos e aumentando a assertividade dos projetos desenvolvidos.

Tendo como base a Metodologia proposta foi elaborada uma proposta de modelo para o desenvolvimento de projetos minerais sustentáveis no Brasil, este modelo está apresentado de forma esquemática na Figura 20. 


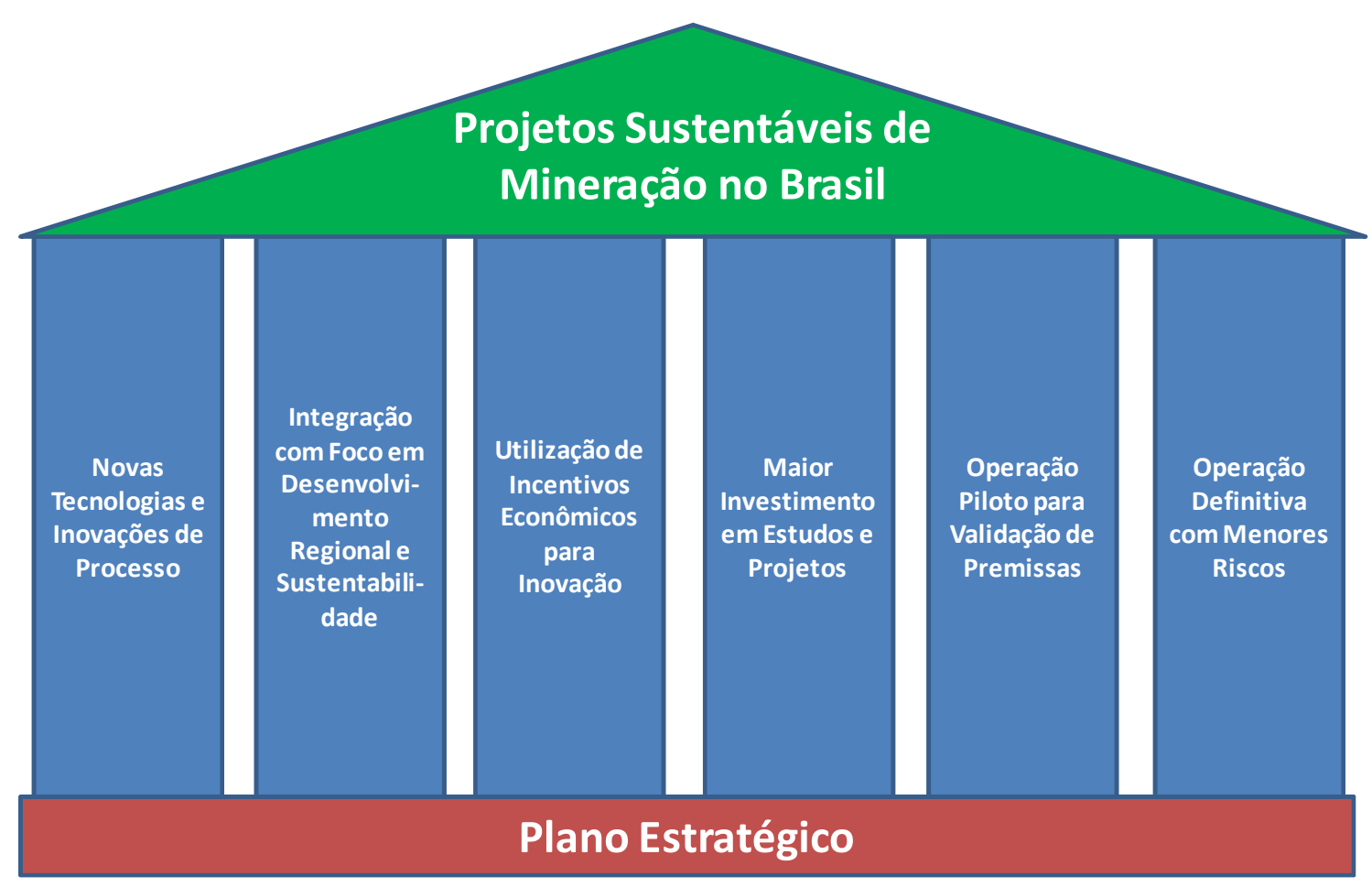

Figura 20: Proposta Esquemática

O modelo proposto para o desenvolvimento de projetos minerais sustentáveis no Brasil possui 6 pilares, que estão explicados a seguir:

1. Novas Tecnologias e Inovações de Processo: na busca por sustentabilidade e competitividade é fundamental a introdução de inovações; ou seja, é necessário romper com o padrão de considerar para os projetos minerais somente tecnologias e práticas consagradas no setor mineral. Muitas vezes existem oportunidades que não são aproveitadas devido a uma visão muito conservadora na estratégia do projeto.

2. Integração com Foco em Desenvolvimento Regional e Sustentabilidade: é necessário enxergar o projeto mineral de forma integrada, não adianta pensar em minério e não considerar o rejeito; é importante considerar minérios secundários e formas de agregar valor aos produtos; além disso, a mineração precisa aproveitar mais as oportunidades de contribuir para o desenvolvimento regional, fugindo do modelo extrativista que é predatório e que gera fortes restrições na implantação e operação de muitos empreendimentos. Para que isto seja possível, é necessário dar a mesma importância ao conhecimento de como a mineração pode se integrar à região forma positiva, que a dada aos estudos sobre as características do depósito mineral (definição de 
recursos) e sobre os processos a serem adotados na sua explotação (definição de reservas).

3. Utilização de Incentivos Econômicos para Inovação: muitos dos problemas de estudos e projetos da mineração estão associados a restrições financeiras para estas etapas; isto é agravado pela falta de linhas de financiamento para estas atividades; no entanto, se forem introduzidas inovações no projeto; poderão ser obtidos financiamento subsidiado e incentivos fiscais para a inovação que permitirão financiar as etapas iniciais com condições bastante atrativas, permitindo a concepção de empreendimentos minerais mais competitivos e com menores riscos. As condições de fomento à inovação estabelecidas pelo governo brasileiro visam fazer com que as empresas transfiram recursos destinados ao pagamento de Imposto de Renda e Contribuição Social para o investimento em ganho de competitividade e sustentabilidade; porém a mineração é o setor econômico que menos utilizou destes incentivos até o momento.

4. Maior Investimento em Estudos e Projetos: com o financiamento subsidiado das etapas de estudos e projetos e ainda com os incentivos fiscais para inovação, é possível obter uma maior disponibilidade de recursos, permitindo investir mais nestas etapas, acarretando no desenvolvimento de empreendimentos minerais mais competitivos e sustentáveis. Este tipo de abordagem é como se chama no mercado de "fazer mais com menos"; pois será possível investir mais, porém isto custará menos para a empresa, pois o governo estará subsidiando o desenvolvimento do empreendimento. Outra grande vantagem no maior investimento em estudos e projetos é a redução dos riscos de implantação e operação.

5. Operação Piloto para Validação de Premissas: atualmente os projetos de mineração são desenvolvidos para se atingir um grande volume em uma única fase, os estudos são efetuados em escala de bancada e muitas dúvidas são desconsideradas pela falta de condição de esclarecê-las de forma consistente. A abordagem proposta propõe que o empreendimento mineral seja desenvolvido em duas fases, uma piloto e a segunda a completa. A primeira fase deverá ser do tamanho adequado para avaliação criteriosa de todas as questões importantes para garantir a 
competitividade e sustentabilidade da futura grande mineração, com a redução dos riscos de implantação e de operação; bem como, dos riscos ambientais, sociais e de mercado; outro aspecto importante a ser considerado para a definição da operação piloto é que ela seja economicamente viável. Esta segmentação na implantação de um grande empreendimento mineral, integrada a visão de uma mineração sustentável, além de possibilitar o financiamento das etapas iniciais e a redução dos riscos, poderá facilitar o licenciamento ambiental do empreendimento, condição que atualmente é uma das maiores barreiras para novos projetos minerais.

6. Operação Definitiva com Menores Riscos: na fase piloto são esclarecidas as principais dúvidas associadas ao aproveitamento do depósito mineral; bem como, definidas as condições adequadas para maximizar a competitividade do empreendimento de forma extremamente consistente, de preferência com certificação segundo os códigos internacionais de mineração (JORC, NI-43.101 e CRIRSCO). Para a operação definitiva já existem mecanismos tradicionais para 0 financiamento; no entanto, o fato de existir uma pequena operação onde é possível comprovar as premissas adotadas no projeto, é extremamente positivo e deverá contribuir para a redução do custo de capital, para facilitar a atração de investidores e para reduzir o custo de seguro de performance. A operação definitiva mais competitiva e sustentável deverá dar condições mais favoráveis ao novo empreendimento, reduzindo os riscos de mercado.

A Metodologia proposta possibilita financiar, de forma atrativa, as etapas de estudos e projetos; bem como, uma pequena operação (piloto) para otimização de processo, avaliação de riscos e desenvolvimento de produtos. Isto pode ser observado na Figura 21. 
A Metodologia proposta possibilita financiar, de forma atrativa, as etapas de estudos e projetos; bem como, uma pequena operação (piloto) para otimização de processo, avaliação de riscos e desenvolvimento de produtos. Isto pode ser observado na Figura 21.

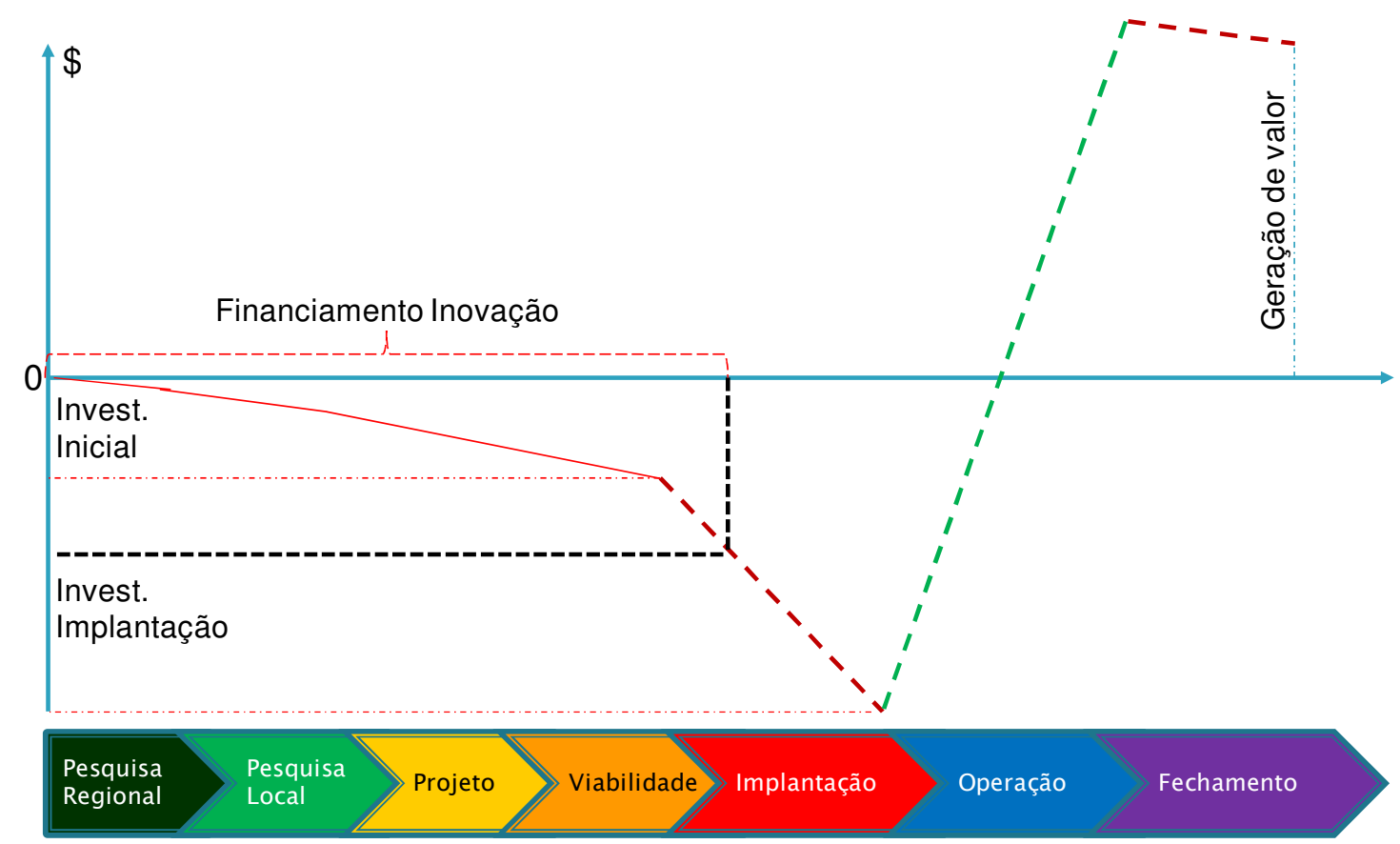

Figura 21: Abrangência do Financiamento de Inovação de um Projeto Mineral

Como pode ser observado na Figura 21, a metodologia proposta possibilita obter financiamento de inovação para as primeiras etapas de um empreendimento mineral, fases de maior risco e sem outras opções de financiamento no Brasil.

Além disso, é possível implantar uma operação piloto, que pode ser uma unidade industrial de pequeno porte, e sua operação por 12 meses, mitigando os riscos de projeto e de operação do novo empreendimento.

As inovações implementadas no projeto e a integração do empreendimento para o desenvolvimento regional, possibilitarão o melhor desempenho, a redução dos impactos ambientais e a obtenção da licença social, contribuindo para a sustentabilidade do negócio e reduzindo os riscos de mercado. 


\section{ILUSTRAÇÃO}

Para modelar o projeto, foi desenvolvida uma planilha padrão para avaliar a viabilidade de um projeto de mineração de ferro no Quadrilátero Ferrífero, considerando as seguintes etapas do processo de mineração:

1. Perfuração

2. Desmonte

3. Carga

4. Transporte

5. Apoio e Infraestrutura

6. Cominuição

7. Concentração

8. Disposição de estéril e rejeito em pilha

9. Disposição de rejeito em barragem

As premissas apresentadas na Tabela 10 foram consideradas na modelagem dos dois casos. 
Tabela 9: Premissas consideradas na modelagem

\begin{tabular}{|l|r|l|}
\hline \multicolumn{1}{|c|}{ Premissas } & \multicolumn{1}{|c|}{ Valor } & Unid./Obs. \\
\hline Reserva (milhões de toneladas) & 100.000 .000 & $\mathrm{t}$ \\
\hline Reserva itabirito compacto & 50.000 .000 & $\mathrm{t}$ \\
\hline Reserva itabirito friável & 50.000 .000 & $\mathrm{t}$ \\
\hline Teor médio de ferro & $40 \%$ & \\
\hline \% itabirito compacto & $50 \%$ & \\
\hline \% itabirito friável & $50 \%$ & \\
\hline Relação estéril/mínério projeto & 0,7 & \\
\hline Relação estéril/mínério operacional & 0,91 & Obs. 01 \\
\hline Eficiência pré-concentração & $50 \%$ & \\
\hline Eficiência flotação & $76 \%$ & \\
\hline Densidade minério & 4,00 & $\mathrm{t} / \mathrm{m3}$ \\
\hline Densidade estéril & 2,50 & $\mathrm{t} / \mathrm{m3}$ \\
\hline Altura de bancada & 10 & $\mathrm{~m}$ \\
\hline Subfuração & 1 & $\mathrm{~m}$ \\
\hline Dias trabalhados por ano & 300 & dia \\
\hline Horas trabalhadas por dia & 20 & $\mathrm{~h}$ \\
\hline Disponibilidade física equipamentos Mina & $90 \%$ & \\
\hline Disponibilidade física equipamentos Usina & $95 \%$ & \\
\hline Relação Dollar x Real & 2,20 & \\
\hline \% Financiamento FINEP & $90 \%$ & \\
\hline \% Financiamento BNDES & $80 \%$ & \\
\hline Taxa Financiamento FINEP (TR - 1\%) & $4 \%$ & \\
\hline Taxa Financiamento BNDES (TR - 2,5\%) & $7,50 \%$ & \\
\hline Prazo de carência FINEP & 36 & $\mathrm{meses}$ \\
\hline Prazo de carência BNDES & 24 & $\mathrm{meses}$ \\
\hline Prazo de amortização FINEP & 84 & $\mathrm{meses}$ \\
\hline Prazo de amortização BNDES & 76 & $\mathrm{meses}$ \\
\hline Taxa capital próprio & 45,00 & US\$/t \\
\hline Preço de venda do minério & & \\
\hline Taxa total de impostos (aproximada) & & \\
\hline & & \\
\hline
\end{tabular}

Obs.: REM operacional maior que a de projeto por necessidade de remoção de todo o estéril antes da exaustão da mina.

A planilha elaborada foi alimentada com informações que buscam caracterizar uma operação tradicional existente, considerando que a implantação de um novo empreendimento, com capacidade de processamento anual de 5 milhões de toneladas de ROM, deve demorar em torno de 5 anos para entrar em operação, financiamento do BNDES para implantação da operação em uma única etapa com taxa anual de TJLP mais $2,5 \%$, sendo financiado $70 \%$ do empreendimento, 
com 24 meses de carência e 76 meses para amortização, conforme resumido na Tabela 9.

A Tabela 11 mostra o caso do modelo inovador, em que o empreendimento de capacidade de 5 milhões de ROM foi desenvolvido em duas etapas: uma fasepiloto com aproximadamente 1 milhão de toneladas por ano que entra em operação no $3^{\circ}$ ano, com financiamento da FINEP, com taxa anual de TJLP menos $1,0 \%$, sendo financiado $90 \%$ do empreendimento, com 36 meses de carência e 120 meses para amortização, e a segunda com o restante da produção a partir do $5^{\circ}$ ano com o modelo de financiamento tradicional.

Na primeira etapa do modelo inovador, foi considerado um investimento $50 \%$ maior para estudos e projetos que no modelo inovador. Nessa etapa, foram efetuados $80 \%$ do investimento para infraestrutura do empreendimento e ainda todos os investimentos em estudos e projetos para a etapa final. 
Tabela 10: Resultados Modelo Tradicional

\begin{tabular}{|c|c|c|c|c|c|c|c|c|c|c|c|}
\hline & Descrição & Ano 1 & Ano 2 & Ano 3 & Ano 4 & Ano 5 & Ano 6 & Ano 7 & Ano 8 & Ano 9 & Ano 10 \\
\hline & Investimento em estudos e projetos & 24.849 .935 & - 12.424 .967 & 4.141 .656 & - & - & - & - & - & - & - \\
\hline \multirow{15}{*}{ 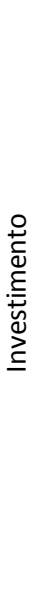 } & Investimento na operação piloto & & & & & & & & & & \\
\hline & Investimento na operação definitiva & - & - & -40.050 .746 & - 179.791 .176 & - & 1.000 .000 & - & -50.063 .433 & - & - \\
\hline & Financiamento dos estudos e projetos & - & - & - & - & - & - & - & - & - & - \\
\hline & \begin{tabular}{|l|} 
Financiamento da operação piloto \\
\end{tabular} & - & - & - & - & - & - & - & - & - & - \\
\hline & Financiamento da operação definitiva & - & - & 32.040 .597 & 143.832 .941 & & & & & & \\
\hline & Saldo financ. estudos e projetos & - & - & - & - & - & - & - & - & - & - \\
\hline & Saldo do financ. da operação piloto & - & - & - & - & - & - & - & - & - & - \\
\hline & Saldo do financ. da operação definitiva & - & - & 32.040 .597 & - 175.873 .538 & -175.873 .538 & -148.104 .032 & -120.334 .526 & 92.565 .020 & 64.795 .514 & 37.026 .008 \\
\hline & Encargos do financ. estudos e projetos & - & - & - & - & - & - & - & - & - & - \\
\hline & Encargos do financ. da operação piloto & - & - & - & - & - & - & - & - & - & - \\
\hline & Encargos do financ. da operação definitiva & - & - & 2.403 .045 & 13.190 .515 & -13.190 .515 & 11.107 .802 & 9.025 .089 & 6.942 .377 & 4.859 .664 & 2.776 .951 \\
\hline & Amortização financ. estudos e projetos & & & & - & - & - & - & - & - & - \\
\hline & Amortização financ. da operação piloto & & & & - & - & - & - & - & - & - \\
\hline & Amortização financ. da operação definitiva & & & & & -27.769 .506 & - 27.769.506 & -27.769 .506 & - 27.769.506 & - 27.769.506 & $-\quad 27.769 .506$ \\
\hline & \begin{tabular}{|l|} 
Fluxo financeiro do investimento \\
\end{tabular} & 24.849 .935 & - 12.424 .967 & 14.554 .850 & 49.148 .751 & -40.960 .021 & - 39.877.308 & - 36.794 .595 & - 84.775 .315 & - 32.629 .170 & 30.546 .457 \\
\hline
\end{tabular}

\begin{tabular}{|c|c|c|c|c|c|c|c|c|c|c|c|}
\hline \multirow{13}{*}{ 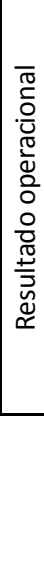 } & Produção operação piloto & - & _ & - & - & & & & & & \\
\hline & Produção operação definitiva & - & - & - & - & 2.268 .657 & 2.268 .657 & 2.268 .657 & 2.268 .657 & 2.268 .657 & 2.268 .65 \\
\hline & Total de produção & - & - & - & - & 2.268 .657 & 2.268 .657 & 2.268 .657 & 2.268 .657 & 2.268 .657 & 2.268 .657 \\
\hline & Receitas & - & - & - & - & 189.659 .701 & 189.659.701 & 189.659 .701 & 189.659 .701 & 189.659.701 & 189.659 .701 \\
\hline & Custo operacional & - & - & - & - & -124.975 .230 & -125.848 .824 & -126.722 .400 & -127.595 .994 & -127.595 .994 & -127.595 .994 \\
\hline & Lucro operacional & - & - & - & - & 64.684 .471 & 63.810 .877 & 62.937.302 & 62.063.708 & 62.063 .708 & 62.063 .708 \\
\hline & Depreciação & & & & & - 17.979 .118 & 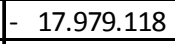 & - 17.979 .118 & - 17.979 .118 & - 17.979.118 & - 17.979 .118 \\
\hline & Encargos financeiros & - & - & 2.403 .045 & $-\quad 13.190 .515$ & - 13.190 .515 & 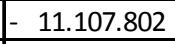 & - 9.025 .089 & \begin{tabular}{|r}
$-\quad 6.942 .377$ \\
\end{tabular} & \begin{tabular}{|l}
$-\quad 4.859 .664$ \\
\end{tabular} & $-\quad 2.776 .951$ \\
\hline & Impostos & - & - & - & - & - 13.405 .935 & -13.889 .583 & - 14.373 .238 & - 14.856 .885 & - 15.689.971 & -16.523 .056 \\
\hline & Lucro líquido & - & - & - & - & 51.278 .536 & 49.921.294 & 48.564 .064 & 47.206 .822 & 46.373.737 & 45.540 .652 \\
\hline & Fluxo de caixa do projeto & 24.849 .935 & - 12.424 .967 & - 14.554 .850 & 49.148 .751 & 10.318 .515 & 10.043 .986 & 11.769 .468 & - 37.568 .493 & 13.744 .568 & 14.994.195 \\
\hline & VPL & $\mathrm{R} \$ 31.605 .525$ & & & & & & & & & \\
\hline & TIR & $11 \%$ & & & & & & & & & \\
\hline
\end{tabular}


Tabela 11: Resultados Modelo Inovador

\begin{tabular}{|c|c|c|c|c|c|c|c|c|c|c|c|}
\hline Descrição & & Ano 1 & Ano 2 & Ano 3 & Ano 4 & Ano 5 & Ano 6 & Ano 7 & Ano 8 & Ano 9 & Ano 10 \\
\hline Investimento em estudos e projetos & - & 37.274 .902 & -18.637 .451 & 6.212 .484 & - & - & - & - & - & - & - \\
\hline Investimento na operação piloto & - & 19.895 .433 & -55.463 .923 & - & & & & & & & \\
\hline Investimento na operação definitiva & & & & & - 124.958 .597 & 1.000 .000 & & & & & \\
\hline Financiamento dos estudos e projetos & & 33.547 .412 & 16.773 .706 & 5.591 .235 & - & - & - & - & - & - & - \\
\hline Financiamento da operação piloto & & 17.905 .890 & 49.917 .530 & - & - & - & - & - & - & - & - \\
\hline Financiamento da operação definitiva & & - & - & - & 99.966 .878 & 800.000 & - & - & - & - & - \\
\hline Saldo financ. estudos e projetos & - & 33.547 .412 & 50.321 .117 & 55.912 .353 & 55.912 .353 & 47.924 .874 & -39.937 .395 & - 31.949 .916 & - 23.962.437 & - 15.974 .958 & 7.987 .479 \\
\hline Saldo do financ. da operação piloto & - & 17.905 .890 & 67.823 .420 & 67.823 .420 & 67.823 .420 & - 58.134.360 & -48.445 .300 & - 38.756 .240 & - 29.067.180 & - 19.378.120 & 9.689 .060 \\
\hline Saldo do financ. da operação definitiva & & - & - & - & 99.966 .878 & -100.766 .878 & -100.766 .878 & -84.856 .318 & -68.945 .758 & - 53.035 .199 & - 37.124 .639 \\
\hline Encargos do financ. estudos e projetos & - & 1.341 .896 & 2.012 .845 & 2.236 .494 & 2.236 .494 & - $\quad 1.916 .995$ & - $\quad 1.597 .496$ & - $\quad 1.277 .997$ & 958.497 & 638.998 & - $\quad 319.499$ \\
\hline Encargos do financ. da operação piloto & - & 716.236 & 2.712 .937 & 2.712 .937 & 2.712 .937 & 2.325 .374 & 1.937 .812 & 1.550 .250 & 1.162 .687 & 775.125 & 387.562 \\
\hline Encargos do financ. da operação definitiva & & - & - & - & 7.497 .516 & 7.557 .516 & 7.557 .516 & 6.364 .224 & 5.170 .932 & 3.977 .640 & 2.784 .348 \\
\hline Amortização financ. estudos e projetos & & & & & 7.987 .479 & 7.987 .479 & 7.987 .479 & 7.987 .479 & 7.987 .479 & 7.987 .479 & 7.987 .479 \\
\hline Amortização financ. da operação piloto & & & & & 9.689 .060 & 9.689 .060 & 9.689 .060 & 9.689 .060 & 9.689 .060 & 9.689 .060 & 9.689 .060 \\
\hline Amortização financ. da operação definitiva & & & & & & & -15.910 .560 & -15.910 .560 & -15.910 .560 & -15.910 .560 & 15.910 .560 \\
\hline Fluxo financeiro do investimento & & 7.775 .166 & 12.135 .919 & 5.570 .679 & 55.115 .205 & 29.676 .424 & 44.679 .922 & - 42.779 .569 & - 40.879 .215 & - 38.978 .862 & 37.078 .508 \\
\hline
\end{tabular}

\begin{tabular}{|c|c|c|c|c|c|c|c|c|c|c|c|}
\hline \multirow{10}{*}{ 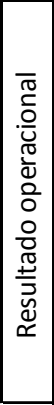 } & Produção operação piloto & - & - & 517.254 & 517.254 & 517253,7313 & 517253,7313 & 517253,7313 & 517253,7313 & 517253,7313 & 517253,7313 \\
\hline & Produção operação definitiva & - & - & - & - & 1.751 .403 & 1.751 .403 & 1.751 .403 & 1.751 .403 & 1.751 .403 & 1.751 .403 \\
\hline & Total de produção & - & - & 517.254 & 517.254 & 2.268 .657 & 2.268 .657 & 2.268 .657 & 2.268 .657 & 2.268 .657 & 2.268 .657 \\
\hline & Receitas & - & - & 43.242 .412 & 43.242 .412 & 189.659 .701 & 189.659 .701 & 189.659 .701 & 189.659 .701 & 189.659 .701 & 189.659 .701 \\
\hline & Custo operacional & - & - & 26.028 .297 & 26.028 .297 & -116.214 .381 & - 118.178 .915 & -120.143 .431 & - 122.107 .966 & -122.107 .966 & -122.107 .966 \\
\hline & Lucro operacional & - & - & 17.214 .115 & 17.214 .115 & 73.445 .321 & 71.480 .786 & 69.516 .270 & 67.551 .736 & 67.551 .736 & 67.551 .736 \\
\hline & Depreciação & & & 11.092 .785 & 11.092 .785 & 21.089 .472 & 21.089 .472 & 21.089 .472 & 9.996 .688 & 9.996 .688 & 9.996 .688 \\
\hline & Encargos financeiros & 2.058 .132 & 4.725 .782 & 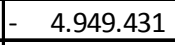 & $-\quad 12.446 .947$ & 11.799 .885 & - 11.092 .824 & - 9.192 .470 & 7.292 .117 & 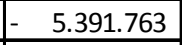 & 3.491 .409 \\
\hline & Impostos & - & - & 9.342 .988 & $-\quad 6.343 .981$ & - 33.093 .963 & - 32.590 .974 & - 32.565.309 & -28.102 .523 & -28.862 .664 & - 29.622 .806 \\
\hline & Lucro líquido & - & - & 7.871 .128 & 10.870 .134 & 40.351 .358 & 38.889 .812 & 36.950 .961 & 39.449 .213 & \begin{tabular}{|l|}
38.689 .071 \\
\end{tabular} & 37.928 .930 \\
\hline & Fluxo de caixa do projeto & 7.775 .166 & 12.135 .919 & 2.300 .448 & - $\quad 44.245 .071$ & 10.674 .934 & 5.790 .110 & 5.828 .607 & 1.430 .002 & 289.790 & 850.422 \\
\hline & VPL & $\mathrm{R} \$ 61.797 .245$ & & & & & & & & & \\
\hline & TIR & $16 \%$ & & & & & & & & & \\
\hline
\end{tabular}


Para o desenvolvimento da operação-piloto, foram considerados os seguintes pontos:

1. Caracterização tecnológica da jazida, com geofísica, sondagem, ensaios tecnológicos e modelagem do depósito;

2. Validação de tecnologias a serem aplicadas na operação-piloto, bem como a definição da necessidade de adequações às condições brasileiras;

3. Estudos ambientais, hidrogeológicos, geotécnicos, de processamento mineral e de otimização dos resíduos;

4. Projetos conceituais, básicos e executivos da operação-piloto sustentável (lavra, usina, depósitos de estéril e rejeito e infraestrutura de apoio);

5. Sistema de gestão integrada para garantia da operação sustentável;

6. Licenciamento ambiental da operação-piloto sustentável;

7. Implantação da operação-piloto;

8. Operação assistida por 12 meses para validação de premissas, otimização de desempenho e desenvolvimento de produtos e do projeto da instalação definitiva.

Como a usina-piloto é focada especialmente no desenvolvimento de inovações tecnológicas, é possível financiá-la por meio de linhas subsidiadas (taxa anual de TJLP menos 1,0\%, sendo financiado $90 \%$ do empreendimento, com 36 meses de carência e 84 meses para amortização).

Além disso, como o foco da operação-piloto é o desenvolvimento de um modelo sustentável de mineração, com a participação de instituições de pesquisa de renomada competência, e os seus impactos são reduzidos pela menor escala, o licenciamento ambiental pode ser agilizado permitindo a implantação no $2^{\circ}$ ano e a operação no $3^{\circ}$.

A segunda fase do empreendimento incorporará as tecnologias validadas na operação-piloto e segue as condições semelhantes ao modelo tradicional.

As inovações consideradas no projeto inovador foram as seguintes: 
1. Perfuração - novo padrão de planejamento e acompanhamento da execução com avaliação de diferentes diâmetros e malhas para permitir o desmonte ultrafino;

2. Desmonte - novo padrão de planejamento, carregamento (explosivos e acessórios) e acompanhamento da execução com avaliação de diferentes razões de carga e arranjos de iniciação para permitir o desmonte ultrafino;

3. Carga - não alterado, porém considerado um ganho de produtividade de $2 \%$ em função da melhoria no desmonte, que reduz a ocorrência de repés e de matacos;

4. Transporte - não alterado;

5. Apoio e Infraestrutura - considerados $80 \%$ dos investimentos totais para serem na fase-piloto, porém sem alteração no custo operacional. Isso ocorre devido a maior parte da infraestrutura ser necessária para a operação-piloto e, dessa forma, pode ser financiada dentro do projeto de inovação;

6. Cominuição - utilização de moinhos com tecnologia russa (moinho semiautôgeno de console e moinho planetário);

7. Concentração - não alterada;

8. Disposição de estéril e rejeito em pilha - considerado o espessamento de rejeitos e a disposição em pilha;

9. Disposição de rejeito em barragem - não alterado, porém o volume foi reduzido em função do volume de rejeito disposto em pilha.

Para comparar o modelo tradicional com o inovador, foram consideradas novas tecnologias com as quais a equipe do NAP.Mineração teve algum envolvimento e que foram consideradas com potencial para tornar o processo de mineração mais sustentável.

As variáveis, os parâmetros de processo e os resultados que foram considerados em cada um dos modelos desenvolvidos estão apresentados na Tabela 12. 
Tabela 12: Dados considerados em cada um dos modelos

\begin{tabular}{|c|c|c|c|c|}
\hline Etapa do Processo & Resumo de Parâmetros & Unidade & Inovador & Tradicional \\
\hline \multirow{7}{*}{ 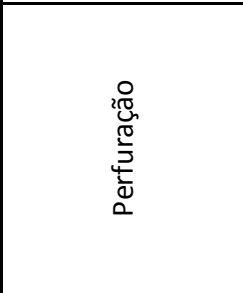 } & Malha minério & $\mathrm{m} 2$ & 5 & 20 \\
\hline & Malha estéril & $\mathrm{m} 2$ & 30 & 30 \\
\hline & Produtividade no minério & $\mathrm{m} / \mathrm{h}$ & 12 & 12 \\
\hline & \begin{tabular}{|l|} 
Produtividade no estéril \\
\end{tabular} & $\mathrm{m} / \mathrm{h}$ & 12 & 12 \\
\hline & Custo horário de perfuração & $\mathrm{R} \$ / \mathrm{h}$ & 160 & 160 \\
\hline & Custo de perfuração por tonelada de minéri & $\mathrm{R} \$ / \mathrm{t}$ & 0,73 & 0,18 \\
\hline & Custo de perfuração por tonelada de estéril & $\mathrm{R} \$ / \mathrm{t}$ & 0,20 & 0,18 \\
\hline \multirow{7}{*}{ 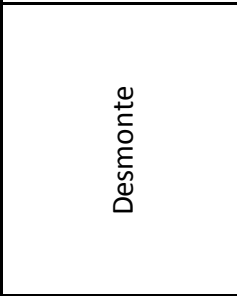 } & \begin{tabular}{|l|} 
Razão de carga minério \\
\end{tabular} & $\mathrm{g} / \mathrm{t}$ & 600 & 150 \\
\hline & Razão de carga estéril & $\mathrm{g} / \mathrm{t}$ & 100 & 100 \\
\hline & \begin{tabular}{|l|} 
Preço explosivo \\
\end{tabular} & $\mathrm{R} \$ \mathrm{~kg}$ & 4,20 & 4,20 \\
\hline & Preço acessórios & $\mathrm{R} \$$ /furo & 18,60 & 9,30 \\
\hline & Custo de gestão de desmonte & $\mathrm{R} \$ / \mathrm{t}$ & 0,08 & 0,02 \\
\hline & Custo por tonelada de minério & $\mathrm{R} \$ / \mathrm{t}$ & 2,70 & 0,67 \\
\hline & Custo por tonelada de estéril & $\mathrm{R} \$ / \mathrm{t}$ & 0,53 & 0,46 \\
\hline Carga & \multicolumn{4}{|c|}{ No modelo inovador foi considerado um ganho de $2 \%$ na produtividade } \\
\hline Transporte & \multicolumn{4}{|c|}{ Sem alteração nos dois modelos } \\
\hline Apoio e Infra & \multicolumn{4}{|l|}{ Sem alteração nos dois modelos } \\
\hline \multirow{8}{*}{ 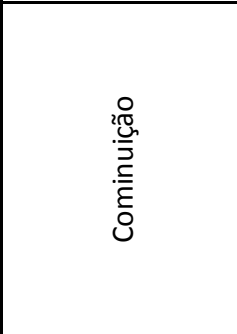 } & Capacidade Instalada Britagem & $t / h$ & - & 610 \\
\hline & Investimento Britagem & $\mathrm{R} \$ / \mathrm{t}$ & - & 5.000 \\
\hline & Custo horário de Britagem & $\mathrm{R} \$ / \mathrm{h}$ & - & 1.000 \\
\hline & Capacidade Instalada Moagem & $t / h$ & 770 & 660 \\
\hline & Investimento Moagem & $\mathrm{R} \$ / \mathrm{t}$ & 25.000 & 30.000 \\
\hline & Custo horário de Moagem & $\mathrm{R} \$ / \mathrm{h}$ & 8.000 & 10.000 \\
\hline & Investimento Total Cominuição & $\mathrm{R} \$ / \mathrm{t}$ & 25.000 & 35.000 \\
\hline & Custo Total Cominuição & $\mathrm{R} \$ / \mathrm{t}$ & 10,39 & 16,79 \\
\hline Pré concentração & \multicolumn{4}{|l|}{ Não foi considerada } \\
\hline \begin{tabular}{|l|} 
Flotação \\
\end{tabular} & \multicolumn{4}{|l|}{ Sem alteração nos dois modelos } \\
\hline \multirow{13}{*}{ 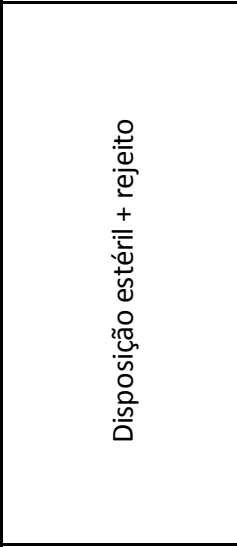 } & Quantidade rejeito gerado & t/ano & 2.731 .343 & 2.731 .343 \\
\hline & Eficiência tratamento rejeito & $\%$ & $70 \%$ & $0 \%$ \\
\hline & Investimento em tratamento de rejeito & $\mathrm{R} \$ / \mathrm{t}$ & 1,00 & - \\
\hline & Custo de tratamento de rejeito & $\mathrm{R} \$ / \mathrm{t}$ & 0,20 & - \\
\hline & Quantidade rejeito espessado & t/ano & 1.911 .940 & - \\
\hline & Custo de transporte de rejeito & $\mathrm{R} \$ / \mathrm{t}$ & 1,00 & - \\
\hline & Quantidade estéril disposto & t/ano & 4.550 .000 & 4.550 .000 \\
\hline & Total material empilhado & t/ano & 6.461 .940 & 4.550 .000 \\
\hline & \begin{tabular}{|l|} 
Capacidade de disposição em pilha \\
\end{tabular} & $\mathrm{t}$ & 32.309 .701 & 18.200 .000 \\
\hline & Investimento em depósito de estéril+rejeitd & $\mathrm{R} \$ / \mathrm{t}$ & 1,00 & 1,00 \\
\hline & \begin{tabular}{|l|} 
Custo de disposição de estéril+rejeito \\
\end{tabular} & $\mathrm{R} \$ / \mathrm{t}$ & 0,80 & 0,80 \\
\hline & Investimento total tratamento + disposição & $\mathrm{R} \$ / \mathrm{t}$ & 2,00 & 1,00 \\
\hline & \begin{tabular}{|l|} 
Custo total tratamento + disposição \\
\end{tabular} & $\mathrm{R} \$ / \mathrm{t}$ & 1,18 & 0,80 \\
\hline \multirow{7}{*}{ 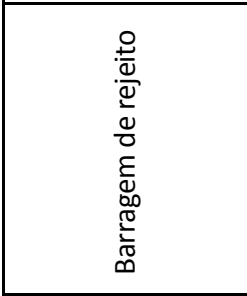 } & Quantidade rejeito para barragem & t/ano & 819.403 & 2.731 .343 \\
\hline & Capacidade da barragem de rejeito & $\mathrm{t}$ & 4.097 .015 & 13.656 .716 \\
\hline & Investimento em Barragem de rejeito & $\mathrm{R} \$ / \mathrm{t}$ & 2,00 & 2,00 \\
\hline & Investimento em Barragem de rejeito & $\mathrm{R} \$$ /ano & 8.194 .030 & 27.313 .433 \\
\hline & Custo de disposição de rejeito em barragem & $\mathrm{R} \$ / \mathrm{t}$ & 1,00 & 1,00 \\
\hline & \begin{tabular}{|l|} 
Custo de transporte de rejeito \\
\end{tabular} & $\mathrm{R} \$ / \mathrm{t}$ & 0,50 & 0,50 \\
\hline & Custo total de disposição de rejeito & $\mathrm{R} \$ \mathrm{t}$ & 1,50 & 1,50 \\
\hline
\end{tabular}




\subsection{Identificação das Variáveis Críticas que Impactam nos Fluxos de Caixa Anuais do Projeto bem como em seus Indicadores}

Foram selecionadas as seguintes variáveis críticas normalmente adotadas na tomada de decisão em projetos de mineração para efetuar uma bateria de simulações:

1. Teor de ferro;

2. Disponibilidade física dos equipamentos de lavra;

3. Disponibilidade física dos equipamentos da usina;

4. Preço de venda do minério.

\subsection{Detalhamento da Simulação de Monte Carlo}

Um dos principais problemas na tomada de decisões consiste em medir o nível e risco de cada escolha, uma vez que não se pode ter certeza do resultado de variáveis como (a) preço do minério que depende das forças de mercado, (b) teor de minério que depende das condições geológicas, (c) disponibilidade física dos equipamentos de lavra e (d) disponibilidade física dos equipamentos da usina.

Nesse caso, pode-se modelar a variabilidade de variáveis como essas por meio de distribuições de probabilidade.

O impacto das variáveis críticas consideradas no VPL dos modelos tradicional e inovador está apresentado na Tabela 13.

Tabela 13: Avaliação do Impacto das Variáveis Críticas

\begin{tabular}{|l|r|r|}
\hline \multicolumn{1}{|c|}{ Variável } & Modelo Inovador & Modelo Tradicional \\
\hline Preço & $94,3 \%$ & $94,3 \%$ \\
\hline Teor & $5,0 \%$ & $4,7 \%$ \\
\hline Disponibilidade Eq. Mina & $0,2 \%$ & $0,4 \%$ \\
\hline Disponibilidade Eq. Usina & $0,0 \%$ & $0,0 \%$ \\
\hline
\end{tabular}

Nas simulações, foi identificado que o impacto sobre o risco do VPL das variáveis críticas consideradas está concentrado no preço de venda do minério de ferro. 
Isso significa que, das quatro variáveis críticas consideradas no estudo, o preço de venda é a principal, com $94,3 \%$ do peso sobre o resultado do risco do VPL, por isso, neste trabalho, somente a variabilidade do preço do minério e suas consequências em termos de risco do VPL foram consideradas.

Assume-se que o preço do minério pode ser modelado por meio de uma distribuição log-normal com os parâmetros na Tabela 14.

Tabela 14: Parâmetros utilizados nas simulações

\begin{tabular}{|c|c|}
\hline Média do preço do minério de ferro (US\$/t) & $\begin{array}{c}\text { Desvio padrão do preço do minério de ferro } \\
(\mathrm{R} \$ / \mathrm{t})\end{array}$ \\
\hline 30 & 6 \\
\hline 35 & 7 \\
\hline 40 & 8 \\
\hline 45 & 9 \\
\hline 50 & 10 \\
\hline 55 & 11 \\
\hline 60 & 12 \\
\hline 65 & 13 \\
\hline
\end{tabular}

Nota-se que foram testados diferentes valores para a média do preço do minério de ferro. O valor do desvio padrão se mantém igual a $20 \%$ da média. Destacase que modelo mais elaborado para representar o preço do minério de ferro é recomendável, mas o propósito deste artigo não é exatamente em criar modelos para previsão de preços, mas sim avaliar os níveis de risco em três situações: (a) preços elevados, (b) preços muito baixos e (c) preços estáveis.

O modelo de variabilidade do preço do minério foi inserido no fluxo de caixa de avaliação dos projetos com e sem inovação tecnológica. Depois, foi realizada uma simulação de Monte Carlo contendo 1000 iterações. 


\section{RESULTADOS E DISCUSSÕES}

$\mathrm{Na}$ Figura 22, encontram-se os resultados de valor esperado em função de diferentes valores da média da distribuição log-normal que foi empregada para a modelagem da variabilidade do preço do minério de ferro (o desvio padrão corresponde a $20 \%$ da média).

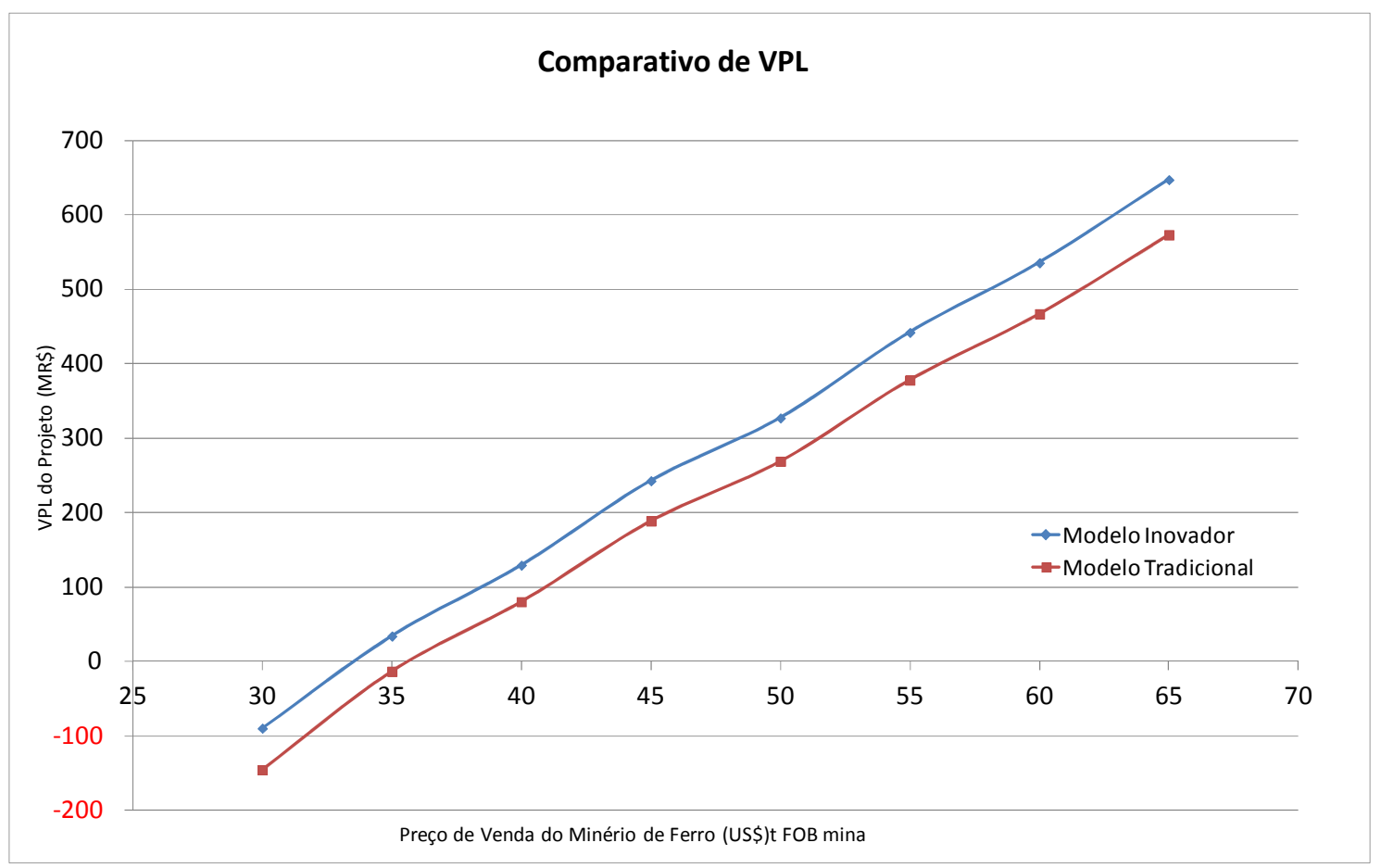

Figura 22: Valor esperado do VPL em função de diferentes parâmetros da distribuição lognormal

Conforme mostrado na Figura 22, para baixos valores de preços, ambos os projetos devem ser descartados. Nota-se que o break-even do projeto com inovação tecnológica é mais baixo que o projeto com tecnologia tradicional e isso mostra o valor agregado pela tecnologia como forma de robustez em ambiente de riscos. Além disso, pode-se ver que, no caso de preços mais altos, o valor esperado do projeto com inovação tecnológica tende a diminuir.

$\mathrm{Na}$ Figura 23, encontra-se uma ilustração da sensibilidade do risco de VPL negativo em função do aumento na média da distribuição normal do preço do minério de ferro. 


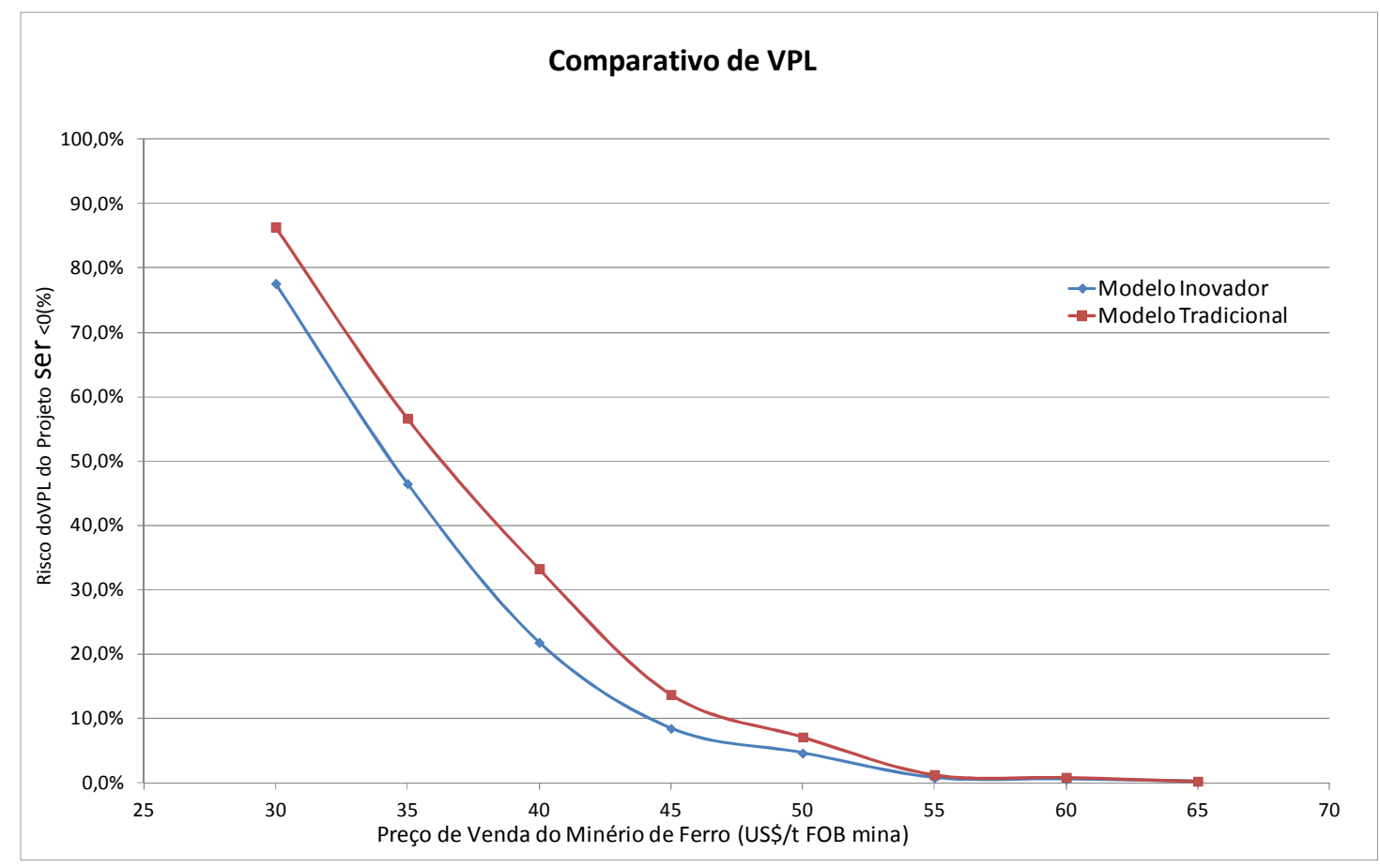

Figura 23: Risco de VPL negativo em função de diferentes parâmetros da distribuição lognormal

A Figura 23 mostra que, se o preço for alto, ou seja, acima de US $\$ 55 /$ t, o projeto não possui risco e tanto faz com ou sem inovação tecnológica. Mas, para preços baixos, o nível de risco de VPL negativo é menor para o caso do projeto com inovação tecnológica.

Na Figura 19, encontra-se uma ilustração da diferença de VPL entre os modelos inovador e tradicional em função do aumento na média da distribuição normal do preço do minério de ferro. 


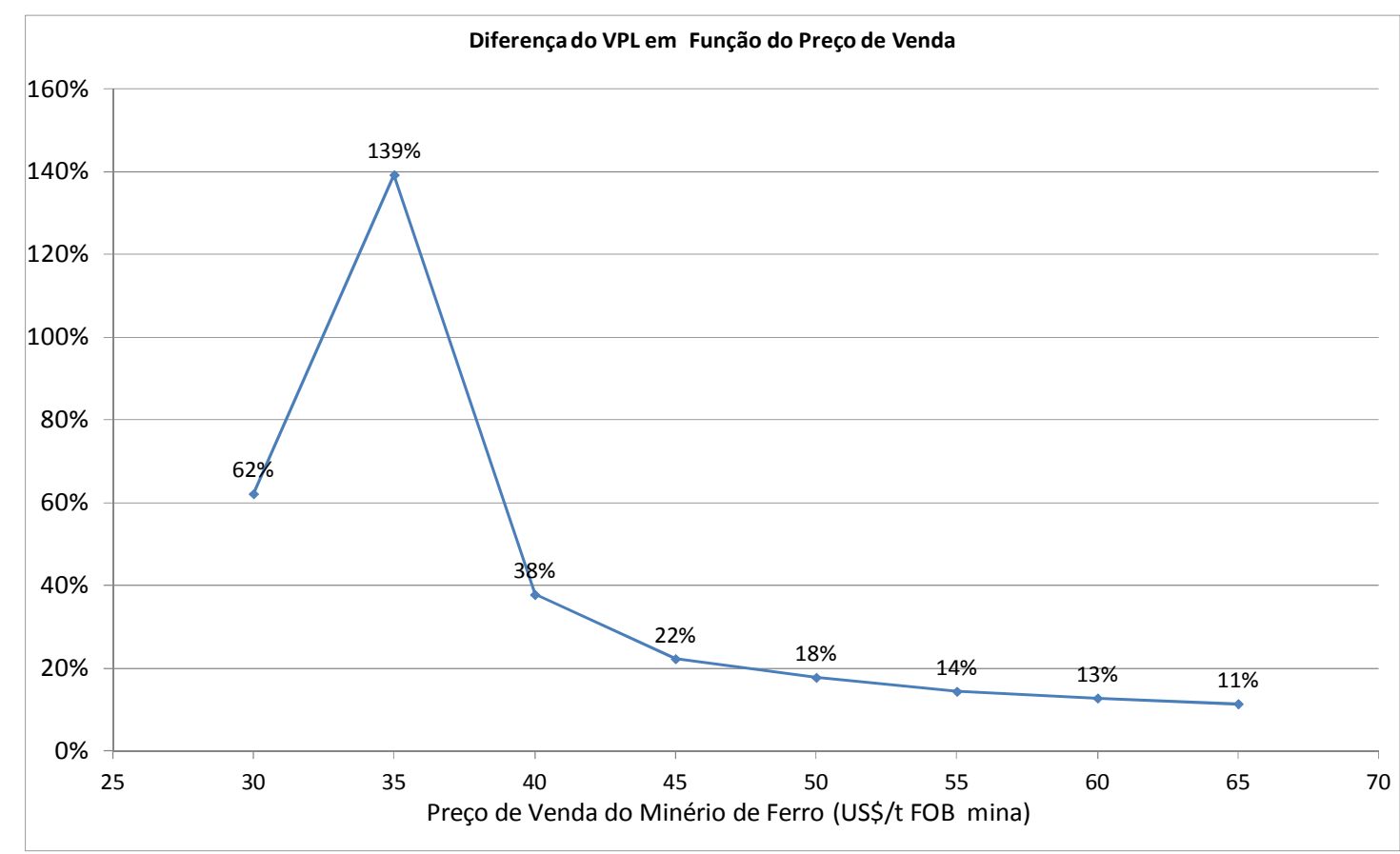

Figura 24: Diferença de VPL entre os modelos inovador e tradicional em função de diferentes parâmetros da distribuição log-normal

Na Figura 24, observa-se que, se o preço for baixo, ou seja, abaixo de US $\$ 50 / t$, o projeto inovador apresenta um resultado muito superior ao tradicional. Mas, para preços altos, essa diferença tende a reduzir.

Pode-se observar pelos resultados obtidos que o modelo inovador é muito mais competitivo que o modelo tradicional, mais atratividade econômica e menos riscos, principalmente, em momentos em que o mercado não for favorável.

A Figura 25 mostra a faixa em que o impacto do modelo inovador no risco do VPL é mais intenso. 


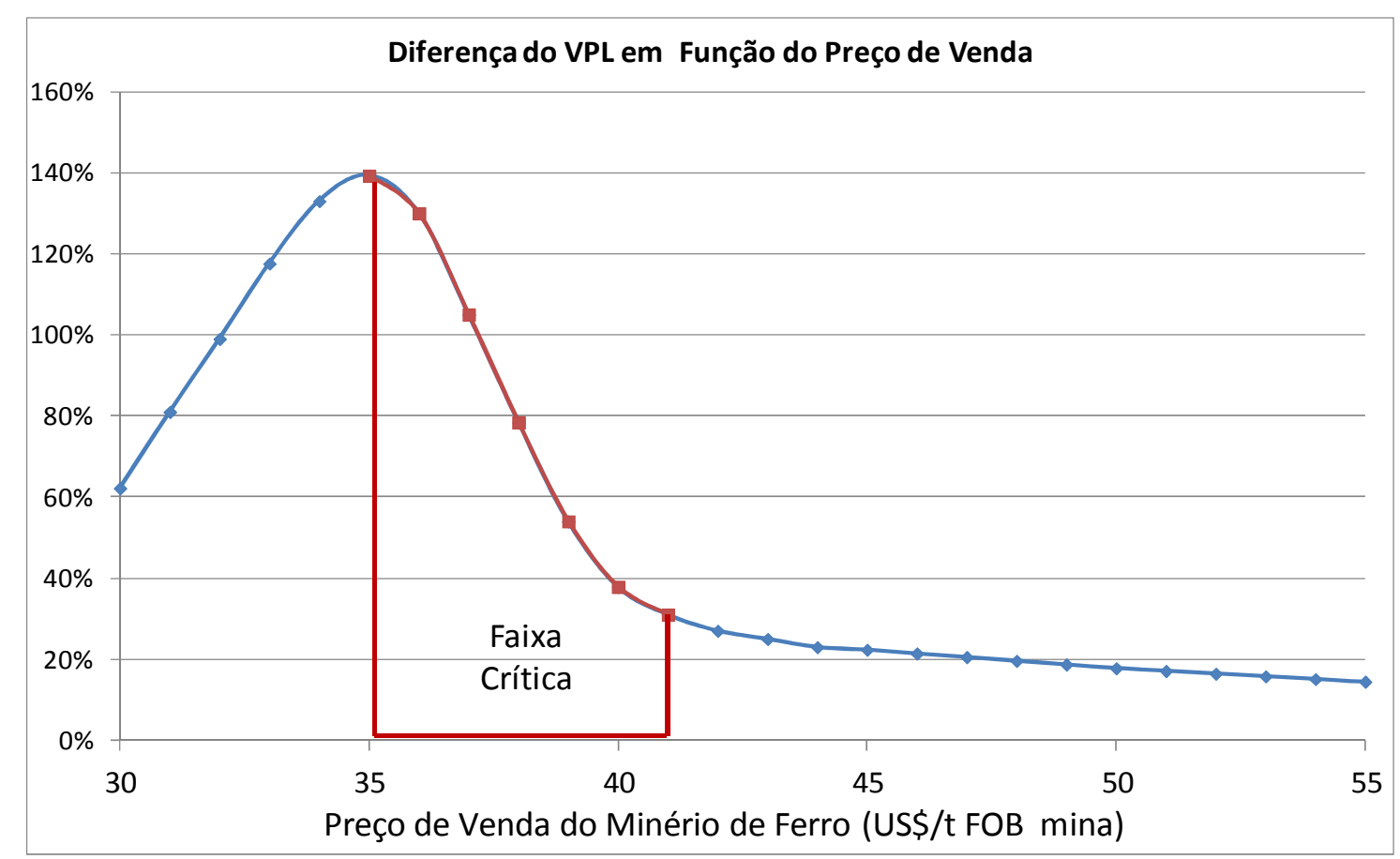

Figura 25: Faixa crítica de risco do VPL

A Figura 25 mostra a faixa crítica em que o impacto do modelo inovador no Risco do VPL é mais intenso, significando que, em momentos de preços baixos, a competitividade do modelo inovador será muito maior que a do modelo conservador. 


\section{CONCLUSÕES}

Pelos resultados obtidos no exemplo de aplicação, a adoção da proposta de modelo para o desenvolvimento de projetos minerais sustentáveis no Brasil poderá impactar fortemente o setor mineral brasileiro, facilitando o financiamento das etapas iniciais, melhorando a competitividade, reduzindo os riscos, melhorando a imagem e, principalmente, contribuindo para a mudança cultural dos lideres da mineração brasileira.

O Brasil é o país com maior potencial mineral do mundo (IBRAM, 2007), mas não consegue aproveitá-lo na sua totalidade por uma série de razões, sendo que podem ser considerados como os principais fatores que dificultam 0 desenvolvimento da mineração brasileira os seguintes pontos:

1. Dificuldade de financiamento e elevadas taxas de juros;

2. Elevados impostos e encargos;

3. Morosidade do licenciamento ambiental;

4. Alto custo do Brasil.

Apesar das dificuldades, o nível tecnológico e de conhecimento em muitas operações de mineração no Brasil se elevou nos últimos anos, equiparando-se aos melhores padrões mundiais, mas o rudimentar persiste em atividades descapitalizadas, como as pedreiras, a mineração cimenteira, a extração de carvão mineral, as técnicas baseadas em drenagem de aluviões, a extração de pedras ornamentais e o precário garimpo que faz enormes estragos ambientais e produz violência no norte do país. (FURTADO, 2013).

Como a mineração estruturada não consegue ocupar todo o espaço para o aproveitamento do potencial mineral brasileiro, sobra espaço para o crescimento da mineração irresponsável e predatória, acarretando o agravamento dos problemas decorrentes desse tipo de empreendimento e afetando fortemente 0 econômico, o ambiental e o social.

Por outro lado, o fortalecimento da mineração responsável e competitiva poderá contribuir para o desenvolvimento regional sustentável, dessa forma, o 
desenvolvimento de projetos inovadores de mineração possibilitará a superação das principais dificuldades apontadas pelo setor.

Para que a mineração brasileira seja mais competitiva e sustentável, é necessário promover a inovação, onde o principal desafio é fazer com que as pessoas passem a pensar de forma diferente (BAMBER, 2014). Para que isso ocorra, é fundamental a mudança cultural dos líderes do setor de mineração, possibilitando que as empresas se ajustem às condições necessárias ao desenvolvimento de projetos inovadores e sustentáveis, de forma a conseguirem se beneficiar dos incentivos para a inovação estabelecidos pelo governo brasileiro.

O investimento em mineração é maior quando o mercado está em alta, porém as empresas buscam aproveitar esse cenário por meio de projetos conservadores e de grande escala, repetindo modelos que estão tendo sucesso na época em que se está iniciando o desenvolvimento.

A proposta apresentada é desenvolver projetos minerais inovadores que possibilitem o máximo aproveitamento dos recursos minerais, a minimização dos impactos ambientais e a integração com a comunidade local, contribuindo para o desenvolvimento regional.

Conforme descrito na modelagem, a proposta é que os projetos sejam desenvolvidos em duas etapas: a primeira de menor porte (piloto), que permite avaliar de forma efetiva os riscos e os impactos associados ao projeto, facilitando o licenciamento ambiental e se beneficiando com os incentivos existentes para a inovação (financiamento subsidiado e incentivos fiscais), e a segunda de maior porte, com menos riscos, mais competitividade e mais facilidade de captação de recursos para o investimento.

No exemplo de aplicação do modelo proposto, apesar de investir $50 \%$ a mais em estudos e projetos do que no modelo tradicional, o VPL e a TIR foram melhores no modelo inovador, além de uma forte redução no risco do VPL.

Além da melhoria nos parâmetros econômicos, o método proposto possibilita 0 financiamento subsidiado e incentivos fiscais para a etapa de maior risco do 
empreendimento; desta forma, é possível investir mais em mitigação do impacto ambiental e contribuição para o desenvolvimento social da região; tornando o empreendimento menos impactante nos aspectos ambientais e sociais.

Os resultados obtidos neste estudo justificam a sua continuidade, sendo para isso proposto o desenvolvimento de um projeto de mineração para a avaliação da consistência das hipóteses consideradas e, dessa forma, validação do novo modelo proposto.

A aplicação desse modelo em um projeto real de mineração possibilitará criar um novo padrão de mineração de ferro pela introdução de novas tecnologias e abordagens, validando as hipóteses adotadas neste estudo.

A comprovação da efetividade do novo modelo proposto para o desenvolvimento de projetos minerais poderá contribuir para a mudança cultural dos líderes e, consequentemente, para a competitividade e sustentabilidade da mineração brasileira. 


\section{REFERÊNCIAS BIBLIOGRÁFICAS}

ABIMAQ-IPDMAC/DCEE, $2011 \quad$ - Disponível em: <http://www.abimaq.org.br/Arquivos/Html/DEEE/Comportamento\%20da\%20pro du\%C3\%A7\%C3\%A30\%202010\%20\%28Mario\%29\%20.pdf>. (consultado em 13 janeiro de 2012)

Alasoini, T. (2013) Promoting employee-driven innovation: Broad-based innovation policy in practice. In Proceedings of the Participatory Innovation Conference PIN-C 2013.

Bamber A., 2014 - Fonte: http://business.financialpost.com/2014/09/30/in-riskaverse-mining-sector-innovation-begins-with-taking-the-guesswork-out-ofsorting-rock/, site visitado em out/2014

Barreto, M.L. (2001) "Mineração e desenvolvimento sustentável: Desafios para o Brasil", CETEM/MCT, pag. 187-190

Batterham, R.J. (2006) Sustainability - the next chapter, Chemical engineering Science, Vol. 61, pp. 4188-4193.

Bessant, J. (2003), High involvement innovation: building sustainable competitive advantage through continuous change, Chichester, UK, Wiley.

Bessant, J., \& Caffyn, S., 1997, "High involvement innovation through continuous improvement”, International Journal of Technology Management, 14(1): 7-28.

Bresciani, L.P. (1999), "Labour and innovation: contemporary roads in the Brazilian truck industry", paper presented at the 7th GERPISA colloquium, Paris, 16-18 June.

Bresser-Pereira, Luiz Carlos. Do estado patrimonial ao gerencial. In: pinheiro, Wilheim e Sachs (orgs.), Brasil: Um Século de Transformações. S. Paulo: Cia. das Letras, 2001: 222-259.

Canuto, O., Cavallari, M. and Guilherme Reis, J. (2013) The Brazilian competitiveness cliff. World Bank, February 2013, Number 105.

Castro, A (2011). "Indústria brasileira está perdendo competitividade internacional, avisam especialistas". Agência Senado. Senado Federal do Brasil. Disponível em: <http://www.senado.gov.br/noticias/industria-brasileira-estaperdendo-competitividade-no-mercado-internacional-avisam-especialistas.aspx >. (consultado em 05 de janeiro de 2011)

Claro, P.B.O.; Claro, D.P.; Amâncio, R. Entendendo o conceito de sustentabilidade nas organizações. Revista de Administração, São Paulo, v. 43, n. 4, p. 289-300, out./dez. 2008. Disponível em: <http://www.revistas.usp.br/rausp/article/view/44483>. Acesso em: 19 Nov.2014. DOI: http://dx.doi.org/10.1590/S0080-21072008000400001. 
Cohen, Michael D.; March, James G.; Olsen, Johan P. (1972). "A Garbage Can Model of Organizational Choice". Administrative Science Quarterly 17 (1): 1-25. Cole, 2002. http://asq.org/pub/qmj/past/vol8_issue4/cole.html

Conger, J.A. \& Kanungo, R.N. 1988. The empowerment process: integrating theory and practice. Academy of management review, Vol. 13, pp 471-482.

De Tomi, G.; Passos, A.O.; Marin, T.; Caranassios, A. (2010) "Innovation Challenges and Opportunities within the Brazilian Mining Industry", Congresso Triple Helix 8 (Barcelona/Espanha), pp. 4

Deloitte - Competitividade da Industria de Transformação Brasileira, pp. 46 - 49 Deming, W. Edwards (1986). Out of the Crisis. MIT Center for Advanced Engineering Study. ISBN 0-911379-01-0.

Enriquez, M.A.R.S. Mineração e desenvolvimento sustentável: é possível conciliar? REVIBEC: Revista Iberoamericana de Economía Ecológica, Barcelona, v. 12, p. 51-66, 2009.

Erber, F.B. (2004) Innovation and the development convention in Brazil. Revista Brasileira de Inovação, Vol. 3, No. 1, pp. 35-54.

Fairbanks, M.; Lindsay, S. (2000) "Arando o Mar - Fortalecendo as fontes ocultas do crescimento em países em desenvolvimento", Cap. 5,

Faoro, R. Os donos do poder, 2001.

Filippou, D. and King, M.G. (2011) R\&D prospects in the mining and metals industry, Resources Policy, Vol. 36, pp. 276-284.

FINEP, $2012 \quad-\quad$ Disponível em: <http://www.finep.gov.br/programas/inovabrasil.asp\#prazo>. (consultado em 13 janeiro de 2012)

Harmaakorpi, V. and Melkas, H. (2012) Two modes of practice-based innovation. Epilogue in Melkas, H. and Harmaakorpi, V. (Eds.) "Practice-based innovation: Insights, applications and policy implications", Springer.

http://pessoal.educacional.com.br/up/2600001/629690/1\%20administra\%C3\%A 7\%C3\%A30\%20p\%C3\%BAblica\%20no\%20s\%C3\%A9culo\%20XXI.pdf>. (consultado em 31 de maio de 2012)

Imai, M (1986) Kaizen - The Key to Japan's Competitive Success, McGraw-Hill Publishing Company, New York.

Indústria da Mineração, IBRAM, Ano II - Número 11 (2007), pp. 13

IBRAM, Recursos naturais e desenvolvimento - estudos sobre o potencial dinamizador da mineração na economia brasileira - João Furtado e Eduardo Urias, 2013, pag.: 175, 
Kallio, A. and Bergenholtz, C. (2012) Enhancing organisational absorptive capacity by reframing an outdated suggestion box: an action research study. International Journal of Innovation and Learning (Print), vol. 12, p. 414-429,

Klippel, A.F., Petter, C.O. and Antunes Jr., J.A.V. (2008) Management innovation, a way for mining companies to survive in a globalized world, A commentary in Utilities Policy, Vol. 16, pp. 332-333.

Kneipp, J.M.; Gomes, C.M.; Carpes, A.M. Perspectivas da gestão para sustentabilidade em empresas do setor mineral. Revista Gestão \& Tecnologia, Pedro Leopoldo, v. 12, n. 3, p.197-222, set./dez. 2012

Kwak, Y.H. and Anbari, F.T. (2006) Benefits, obstacles, and future of six sigma approach, Technovation, Vol. 26, pp. 708-715.

Liker, J. (2011) The Toyota way. A lecture in Lappeenranta University of Technology. 3.6.2011

Lundvall, B.- $A^{\circ}$. (2007). Innovation system research: Where it came from and where it might go. Globelics Working Paper Series No. 2007-01. The Global Network for Economics of Learning, Innovation, and Competence Building System. http://dcsh.xoc.uam.mx/eii/globelicswp/wpg0701.pdf. Accessed 29 December 2010.

Martins, Luciano. Reforma da Administração Pública e cultura política no Brasil: uma visão geral. ENAP, 1997

Menezes, N. F. (2012) Produtividade na Industria

MCT, 2012 - Relatório Anual da Utilização dos Incentivos Fiscais - Ano Base 2011, pp. 18

Munroe, T.; Westwind, M. (2008) "Silicon Valley - The Ecology of Innovation", Capítulo 3, pp. 169-173

Passos, A. O., Sahão, H. and De Tomi, G. (2010) Gestão sistêmica na mineração, 65ำ Congresso da assosiação Brasileira de Metalurgia, Materiais e Mineração

Passos, A.O. and De Tomi, G. (2012) Gestão de inovação para a mineração Brasileira.

Portal Brasil, 2012 <http://www.brasil.gov.br/noticias/arquivos/2012/05/31/brasil-cai-duas-posicoesem-ranking-de-competitividade-mundial-aponta-estudos. (consultado em 31 de maio de 2012)

Presidência da República - Casa Civil - Subchefia para Assuntos Jurídicos. Decreto № 5.798, de 7 de junho de 2006. Regulamenta os incentivos fiscais às atividades de pesquisa tecnológica e desenvolvimento de inovação tecnológica, de que tratam os arts. 17 a 26 da Lei no 11.196, de 21 de novembro de 2005, Artigo 2․ 
Presidência da República - Casa Civil - Subchefia para Assuntos Jurídicos. Lei no 11.196, de 21 de novembro de 2005. Dispõe sobre incentivos fiscais para a inovação tecnológica, Artigos 17ํ-19․․

R7, 2012 - <http://noticias.r7.com/economia/noticias/eua-lideram-ranking-decompetitividade-industrial-brasil-fica-em-37-20111117.html>. (consultado em 31 de maio de 2012)

Russell, B. (1999) More With Less: Work Reorganization in the Canadian Mining Industry, University of Toronto Press. 257p.

Silva Saraiva, L.A. and Moura Andrade, M.M. (2009) Educação à distância e desenvolvimento de pessoas no setor de mineração: Um estudo de caso em minas gerais, Revista Gestão e Planejamento, Vol. 10, No. 1, pp. 72-88.

Terra, J.C., Frederick, B., Vernalha, F., Romão, M., Manhães, M. and Leonardi, S. (2012) 10 Dimensões da gestão da inovação. Um abordagem para a transformação organizacional. Elsevier, 317pages.

Thomas, K.W. \& Velthouse, B.A. 1990. Cognitive elements of empowerment: An interpretive model of intrinsic task motivation. Academy of management review, Vol. 15, pp 666-681.

Upstill, G. and Hall, P. (2006) Innovation in the minerals industry: Australia in a global context, Resources Policy, Vol. 31, pp. 137-145.

Valeyre, A., Lorenz, E., Cartron, D., Csizmadia, P., Gollac, M., Illéssy, M. and Makó, C. (2009) Working conditions in the European Union: Work organisation, Dublin: Eurofound.

Wallace, T. (2004) Innovation and hybridization. Managing the introduction of lean production into Volvo do Brazil, International Journal of Operations \& Product Management, Vol. 24, No. 8, pp. 801-819. 